\title{
Insulin/Glucose-Responsive Cells Derived from Induced Pluripotent Stem Cells: Disease Modeling and Treatment of Diabetes
}

\author{
Sevda Gheibi *, Tania Singh, Joao Paulo M. C. M. da Cunha ${ }^{\circledR}$, Malin Fex and Hindrik Mulder * \\ Unit of Molecular Metabolism, Lund University Diabetes Centre, Jan Waldenströms gata 35, Box 50332, \\ SE-202 13 Malmö, Sweden; tania.singh@med.lu.se (T.S.); joao_paulo.da_cunha@med.lu.se (J.P.M.C.M.d.C.); \\ malin.fex@med.lu.se (M.F.) \\ * Correspondence: sevda.gheibi@med.lu.se (S.G.); hindrik.mulder@med.lu.se (H.M.)
}

Received: 18 September 2020; Accepted: 9 November 2020; Published: 12 November 2020

\begin{abstract}
Type 2 diabetes, characterized by dysfunction of pancreatic $\beta$-cells and insulin resistance in peripheral organs, accounts for more than $90 \%$ of all diabetes. Despite current developments of new drugs and strategies to prevent/treat diabetes, there is no ideal therapy targeting all aspects of the disease. Restoration, however, of insulin-producing $\beta$-cells, as well as insulin-responsive cells, would be a logical strategy for the treatment of diabetes. In recent years, generation of transplantable cells derived from stem cells in vitro has emerged as an important research area. Pluripotent stem cells, either embryonic or induced, are alternative and feasible sources of insulin-secreting and glucose-responsive cells. This notwithstanding, consistent generation of robust glucose/insulin-responsive cells remains challenging. In this review, we describe basic concepts of the generation of induced pluripotent stem cells and subsequent differentiation of these into pancreatic $\beta$-like cells, myotubes, as well as adipocyte- and hepatocyte-like cells. Use of these for modeling of human disease is now feasible, while development of replacement therapies requires continued efforts.
\end{abstract}

Keywords: adipocyte; $\beta$-cells; diabetes; hepatocyte; insulin resistance; iPSC; myotube

\section{Introduction}

The prevalence of diabetes, a life-threatening disease, is increasing worldwide; 463 million people have diabetes and 374 million exhibit impaired glucose tolerance. It has been estimated that 578 million people by the year 2030, and 700 million by the year 2045, will suffer from diabetes [1]. Type 2 diabetes (T2D), which accounts for $90-95 \%$ of all diabetes, is essentially characterized by pancreatic $\beta$-cell dysfunction and insulin resistance [2]. Therefore, restoration of insulin-producing $\beta$-cells, as well as insulin-responsive cells, is a logical therapeutic strategy not only for type 1 diabetes (T1D) but also for T2D.

In recent years, generation of transplantable glucose-responsive, insulin-secreting $\beta$-like cells, and insulin-responsive cells in vitro is not only theoretically attractive but is also becoming feasible. Pluripotent stem cells (PSC), such as embryonic stem cells (ESC) and induced PSCs (iPSC), are potential alternative sources of insulin- and glucose-responsive cells owing to their ability to differentiate into all major somatic cell lineages and their unlimited renewal capacity (reviewed in [3-6]). To this end, PSCs exposed to various growth factors and signaling molecules at specific doses and in a particular sequence, typically mimicking embryonic development, results in successful differentiation into glucoseor insulin-responsive cells [7-9]. In addition to replacement therapeutic strategies, and presently more feasible, differentiated PSCs may serve as valuable platforms for drug discovery and elucidation of disease mechanisms in diabetes research, both as in vitro and in vivo model systems [10,11]. 
Although both ESCs and iPSCs are PSCs, for several reasons iPSCs may be considered as the first choice for modeling and treatment of diseases. There are ethical concerns regarding the use of human embryos for research purposes. In addition, genetic manipulation will likely be required to introduce specific mutations when using ESCs as a model of a genetic disorder. In contrast, iPSCs can be derived from individuals carrying a specific mutation or genetic variant that may be of pathogenetic relevance (for more detail see [12]). For therapy, autologous transplantation of patient-derived iPSC obviates need for immunosuppression although some toxicity may be expected [13,14].

For these reasons, this review will focus on the generation of iPSCs from somatic cells of healthy individuals or patients suffering from various disorders related to T2D and subsequent differentiation of such cells into pancreatic $\beta$-like cells, as well as myotubes, and adipocyte- and hepatocyte-like cells. The limitations and challenges of successful therapeutic application of iPSC-derived cells in diabetes, such as development of methods to substitute these cells for host cells, standardization of the treatment protocols, and quality control will also be discussed.

\section{Reprogramming of Somatic Cells into iPSCs}

iPSCs are generated through reprogramming of somatic cells into an embryonic-like state. This is achieved by transduction of pluripotency-associated transcription factors. This was first shown by use of four transcription factors, KLF4 (Kruppel-like factor-4), OCT-3/4 (octamer-binding transcription factor-3/4), SOX2 (sex determining region Y-box 2), and c-MYC, which can reprogram mouse fibroblast into PSCs, exhibiting morphological and molecular features resembling those of ESCs [13]. The initial efforts were focused on use of retroviral vectors [13] and constitutive lentiviruses [15], as well as inducible lentiviruses [16], for reprogramming. A retroviral strategy which can infect only dividing cells, is however associated with a risk of tumor formation, mainly due to reactivation of the c-MYC transgene $[17,18]$. On the other hand, iPSCs generated without c-MYC virus show decreased tumor frequency but also a reduced efficiency of iPSC generation [19]. To overcome this, another member of MYC, L-MYC, has been used, possessing higher efficiency of iPSC generation but lower tumorigenic activity [20]. Lentivirus, unlike retrovirus, can infect both dividing and non-dividing cells. However, there are concerns regarding incorporation of lentiviral vector sequences into the iPSC genome. Although modifications have been made to the viral-based systems, such as Cre-deletable [21] or inducible lentiviruses [16], use of viral vectors during iPSC generation still lacks the safety required for therapeutic applications.

Transposon-based methods have been applied to remove integrated transgenes from iPSCs. A polycistronic plasmid harboring four factors and a piggyBac transposon have been constructed and integrated into the genome in the presence of piggyBac transposase [22,23]. The inserted fragment is removed by re-expressing transposase following reprogramming. This method demonstrates an efficiency equivalent to retroviral transduction, excises integrated sequences without genome alteration, eliminates the need for viral transduction, and thus serves to create therapeutically usable virus-free iPSCs (reviewed in [24]).

To reduce the limitation of integrative methods, novel non-integrative approaches have been developed for reprogramming purposes. These are divided into four main categories, integration-defective viral delivery (e.g., adenovirus and Sendai viral vectors), episomal delivery, RNA delivery, and protein delivery. Using adenovirus was one of the first attempts to generate integration-free iPSCs. This allows for transient expression of exogenous genes without integration into the genome. Viruses are instead lost by dilution via cell division [25]. The efficiency of this method is, however, low. While the Sendai RNA virus is capable of transducing a wide range of cell types [26], $\sim 10$ cell-passages are required to eliminate the virus from reprogrammed iPSCs. To overcome this problem, temperature-sensitive Sendai viruses have been developed to remove viruses by culture at $38^{\circ} \mathrm{C}$ [27]. As an alternative, reprogramming based on direct delivery of non-replicating (e.g., plasmids and minicircles) or replicating (e.g., oriP/EBNA1) episomal vectors is now available [28]. Serial transfection utilizing one or two plasmids expressing the key reprogramming factors can 
generate iPSC lines free of plasmid integration [20,29]. However, due to the multiple transfections, it may be difficult to control the dose of plasmid that the cells receive over the reprogramming period. Larger plasmids have lower transfection efficiency, which results in fewer cells receiving the appropriate dose of plasmid. Furthermore, the plasmid is diluted faster in actively proliferating cells, leading to downregulation of reprogramming factors [28]. Minicircle expression vectors, which are supercoiled DNA molecules lacking a bacterial origin of replication, show higher transfection efficiency and longer-term transgene expression compared to plasmids [30].

To circumvent the problem of non-replication episomal vectors, oriP/EBNA1 vectors have been developed. This approach successfully generates iPSC colonies and one-third of them are free of plasmid DNA [31]. The reprogramming efficiency of episomal vectors, however, is low, but the efficiency can be improved by suppressing p53 and substituting non-transforming L-MYC for c-MYC [32].

Utilizing mRNA to express reprogramming factors has high efficiency, which can be even further improved by adding Lin28 to the Yamanaka reprogramming factors [33]. Culturing at $5 \% \mathrm{O}_{2}$ with addition of valproic acid in the medium also enhances efficiency [34]. Furthermore, reprogramming factors directly administered as proteins is yet another approach to successfully generate iPSCs. Here, proteins are delivered into cells, fused with specific peptides that mediate the transduction [35]. This method is, however, technically difficult. Generation of recombinant proteins requires fusion of carboxy termini of four reprogramming factors (e.g., HIV transactivator of transcription and poly-arginine domains) [28,36]. The recombinant transcription factors penetrate and cross the plasma membrane of somatic cells within $\sim$ six hours and iPSCs can be obtained after four repeated protein transductions [35].

Numerous small molecules and soluble factors can increase the reprogramming efficiency through several mechanisms, such as inhibition of transforming growth factor- $\beta$ (TGF- $\beta$ ) [37] or Rho-associated, coiled-coil containing protein kinase (ROCK) [38] signaling pathways, inhibition of histone deacetylation [39], induction of glycolysis [40], and increasing functionality of epigenetic modifiers [41]. As chromatin remodeling is a rate-limiting step in the reprogramming of somatic cells, small molecules that alter chromatin modifications (e.g., hydroxamic acid, trichostatin A, and valproic acid) [42] or DNA methylation (e.g., 5'-azacytidine) [42] increase reprogramming efficiency.

Depending on the starting cell types and species, the kinetics of reprogramming are different. This can be due in part to the epigenetic memory in iPSCs; during the reprogramming process, the genes responsible for cell specificity may remain under-reprogrammed [43]. In addition, a variety of genetic and epigenetic aberrations can occur in iPSCs lines. These aberrations along with retained epigenetic markers of somatic cells cause differences in the epigenomes and transcriptomes of iPSCs [44]. The residual signature of epigenomes in iPSCs, known as epigenetic memory, is likely to influence properties of iPSCs.

In summary, several methods have been developed to generate iPSCs. Some hurdles still remain, such as undesirable tumor formation and variable efficiency of reprogramming of different somatic cells (keratinocytes, fibroblasts, hepatocytes, etc.) $[17,45]$. Therefore, the method of obtaining iPSCs needs to be considered carefully to avoid these issues.

\section{3. iPSC-Derived Pancreatic $\beta$-Like Cells}

\subsection{Development of the Pancreas}

Development of the pancreas is, in general, very similar in different vertebrate species. Since ethical considerations limit studies and use of human embryos, knowledge about pancreas development has largely been derived from the study of mouse pancreatic embryogenesis. During gastrulation, the primitive gut tube (foregut, midgut, and hindgut) is formed from definitive endoderm. The foregut is then split to the anterior and posterior foregut [46]. Transient contact of the notochord with the pre-pancreatic endoderm inhibits expression of the critical transcription factor sonic hedgehog (SHH), resulting in evagination of the posterior foregut and formation of the dorsal and ventral pancreatic 
buds [47]. In the pancreatic buds, the transcription factors pancreatic and duodenal homeobox 1 (PDX1), SRY (sex-determining region Y)-box 9 (SOX9), and GATA-binding protein 4 (GATA4), are necessary for pancreas growth [48]. Due to the gut rotation, the pancreatic buds then fuse to form the definitive pancreas. There are two developmental phases: the primary transition is characterized by extensive proliferation of pancreatic progenitor cells and formation of stratified epithelium [46,49], and also endocrine cells, which are mainly polyhormonal, expressing both glucagon and insulin, but also some monohormonal cells [50]. In the secondary transition, proliferation of endocrine progenitors and generation of all islet endocrine cells occurs [46].

Several transcription factors and signaling molecules initiate and regulate pancreatic development (Supplementary Table S1) by the activation or inhibition of basic signaling pathways such as Wnt (wingless-related integration site)/ $\beta$-catenin, $\mathrm{SHH}$, and Notch. Co-expression of key transcription factors, such as PDX1, pancreas transcription factor (PTF1A), FOXA2, SOX9, NKX6.1, and carboxypeptidase $1 \mathrm{~A}$, regulates differentiation of the multipotent progenitor cells into exocrine, endocrine, and ductal lineages of the pancreas [51,52]. Downregulation of Ptf1a and continued expression of $N k x 6.1$ lead to the development of ductal/endocrine lineages, while the exocrine lineage depends on the maintenance of Ptf1a and loss of $N k x 6.1$ [52]. PDX1 in concert with other transcription factors, such as neurogenin 3 (NGN3), NKX6.1, and MAFA, promotes specification and maturation of multipotent progenitor cells into pancreatic $\beta$-cells $[7,53]$.

\subsection{Differentiation of Pancreatic $\beta$-Like Cells from iPSC}

Protocols to generate glucose-responsive pancreatic $\beta$-cells from iPSCs largely follow strategies established for ESCs (Table 1). They are designed to mimic pancreatic organogenesis by sequential treatment of iPSCs with specified growth and differentiation factors in a chemically defined medium. Most protocols are multi-stage including: (a) induction of definitive endoderm, (b) formation of primitive tube, (c) development of posterior foregut, (d) development of progenitor cells, (e) production of immature pancreatic $\beta$-cells, and (f) mature $\beta$-like cells $[7,9,11,14,54]$ (Figure 1). Numerous small and large molecules have been used to promote $\beta$-cell differentiation from iPSCs (Table 2). Transgenic expression of pancreas-specific transcription factors such as FOXA2, PTF1A, PDX1, hepatocyte nuclear factor (HNF) 4A, HNF6, NGN3, PAX4, NEUROD1, NKX6.1, and MAFA is used to evaluate the differentiation efficiency $[7,9,11,14,54]$.

\subsubsection{Induction of Definitive Endoderm}

Formation of definitive endoderm is the rate-determining step in pancreatic differentiation [55]. It is based on mimicking the actions of TGF- $\beta$, Wnt, and nodal signaling by inhibiting the phosphoinositide 3-kinase (PI3K) and glycogen synthase kinase-3 $\beta$ (GSK-3 $\beta$ ) signaling pathways. Use of activin A, a member of the TGF- $\beta$ superfamily, and also Wnt, for induction of undifferentiated iPSCs into definitive endoderm, are important elements that are common to most methods [14,54]. Activin A, mimicking nodal action, promotes iPSCs differentiation into SOX $17^{+}$definitive endoderm. For a response to activin/Nodal, PI3K signaling must be suppressed. For this purpose, compounds such as wortmannin and LY2994002, which inhibit PI3K signaling, have been found to promote definitive endoderm formation [56]. Another signaling molecule, which appears to modify the activity of activin A during the definitive endoderm induction step, is the TGF- $\beta$ superfamily molecule, bone morphogenetic protein 4 (BMP4) [48]. Inclusion of low concentrations of BMP4 along with activin A in the first day of differentiation has been shown to improve the efficiency of definitive endoderm formation [14]. Indeed, a combination of activin A, BMP4, and fibroblast growth factor 2 (FGF2) induces PSC-differentiated endoderm more efficiently than activin A alone [57,58]; it can be even more efficient in the presence of a ROCK inhibitor under serum-free conditions [59].

Inhibition of GSK-3 $\beta$ (using CHIR99021) for induction of definitive endoderm and spheroid formation at the final stage are important for the generation of functional iPSC-derived $\beta$-like cells [60]. CHIR99021, in the presence of BMP4, promotes endodermal cell viability and increases the SOX17 ${ }^{+}$ 
cells rate. Transplantation of these cells into streptozotocin (STZ)-induced diabetic mice reduces blood glucose levels over the next 4 weeks [60]. Expression of pluripotency markers (NANOG, POU5F1, and SOX2) drops during the first days of iPSCs differentiation, while expression of the mesoendodermal stage-specific marker and then the definitive endoderm-specific markers SOX17 and C-X-C chemokine receptor 4 (CXRC4) is increased [11].

\subsubsection{Formation of Primitive Gut Tube and Development of Posterior Foregut}

SHH inhibitors and FGF10 prime definitive endoderm to form cells characteristic of the primitive gut tube. At low concentrations, FGF promotes posterior foregut fate and expression of PDX1, while at higher concentrations it promotes more posterior endoderm fates $[61,62]$. Members of the FGF family, especially FGF7/keratinocyte growth factor (KGF) and FGF10, are commonly used before PDX1 induction to promote formation of the primitive gut tube which is capable of generating the pancreatic epithelium [9,53,57]. Addition of FGF inhibitors, such as SU5402, LY294002, and U1026, blocks the formation of $\mathrm{PDX} 1^{+}$progenitors [63]; therefore $\mathrm{PDX} 1^{+} / \mathrm{NKX} 6.1^{+}$progenitors cannot be developed in the absence of FGF7 [64]. Furthermore, inclusion of FGF4 to the differentiation culture during the retinoic acid-mediated PDX1 induction step enhances PDX1 expression, most likely through increases in progenitor cell survival [65]. SHH acts as an anti-pancreatic factor, as forced expression of SHH inhibits development of the pancreas [66]. Thus, its inhibition in the region of the primitive gut tube gives rise to the pancreas and this is essential for pancreatic specification. The SHH inhibitor, cyclopamine is routinely used during the retinoic acid induction step [11,67]. At this stage, definitive endoderm cell markers are downregulated, while expression of HNF1B and HNF4A is increased [11]. There are other pathways which may play a regulatory role at this step as inclusion of indolactam $\mathrm{V}$, a strong activator of protein kinase C (PKC), raises PDX1, NGN3, NKX2.2 and NKX6.1 expression following retinoic acid treatment $[14,67,68]$.

\subsubsection{Development of Progenitor Cells}

Pancreatic progenitor cells express a group of transcription factors, of which PDX1 and NKX6.1 are critical markers for $\beta$-cell maturation and functionality (for more detail see $[69,70]$ ). $\mathrm{PDX} 1^{+} / \mathrm{NKX} 6 \cdot 1^{+}$ progenitors differentiate into monohormonal $\beta$-cells, while $\mathrm{PDX} 1^{+} / \mathrm{NKX} 6.1^{-}$progenitors differentiate into polyhormonal cells [71,72]. The differentiation efficiency of iPSCs to $\mathrm{PDX} 1^{+} / \mathrm{NKX} 6.1^{+}$progenitors is high under optimized conditions $[70,71,73]$; the $\mathrm{PDX} 1^{+} / \mathrm{NKX} 6.1^{-}$population is further increased when duration of the posterior foregut stage is prolonged [71]. Although the differentiation efficiency of $\mathrm{PDX1}^{+} / \mathrm{NKX} 6.1^{+}$progenitors is reasonably stable, using the same protocol on different iPSC lines leads to a variable NKX6.1 induction, ranging from $37 \%$ to $84 \%$ [74]. This indicates that the differentiation of pancreatic progenitors/ $\beta$-cells also depends on inherent differences across cell lines. Recently, PDX1- ${ }^{-} / \mathrm{NKX} 6.1^{+}$progenitor cells have been found during differentiation of iPSCs to $\beta$-like cells [75]; these progenitor cells have similarities to a subset of the pancreatic mesenchymal stem cells (MSC) that can give rise to $\mathrm{INS}^{+}$cells. PDX1 ${ }^{-} / \mathrm{NKX} 6.1^{+}$progenitors demonstrate downregulation of pancreatic epithelial genes and upregulation of neuronal development genes, indicating that they represent a unique source for generating INS ${ }^{+}$cells of a non-epithelial origin [75].

Expression of NKX6.1 is promoted by use of nicotinamide and EGF, which increase generation of pancreatic progenitors [74]. Additionally, YAP, a member of the Hippo signaling pathway, is involved in progenitor specification and differentiation into functional pancreatic endocrine cells [76]. The Hippo pathway integrates tissue architecture by balancing between progenitor self-renewal and differentiation [77]. YAP expression is downregulated late in NKX6.1 $1^{+}$progenitors and persists upon completion of the differentiation, as $\sim 95 \%$ of endocrine progenitors and insulin-expressing $\beta$-cells do not express YAP. Inhibition of YAP during the specification of early $\mathrm{PDX} 1^{+}$to late $\mathrm{NKX} 6.1^{+}$progenitors decreases the number of NKX6.1 $1^{+}$progenitors, while its inhibition during endocrine specification, leads to differentiation of pancreatic progenitors into $\mathrm{NGN}^{+}$endocrine progenitors and then into 
NKX6.1 ${ }^{+}$C-peptide ${ }^{+} \beta$-cells more efficiently than control cells [76]. Transplantation of iPSC-derived pancreatic $\mathrm{PDX} 1^{+} / \mathrm{NKX} 6.1^{+}$progenitor cells into diabetic mice reverses hyperglycemia [78].

Forskolin (an adenylate cyclase activator), activin receptor-like kinase (ALK5) inhibitors, ROCK inhibitors, $\gamma$-secretase inhibitor XXI, nicotinamide, triiodothyronine (T3), exendin-4, heparin, and dexamethasone also enhance the generation of insulin-expressing cells from PDX $1^{+}$ progenitors $[14,54,79]$. FGF10 acts upstream of notch signaling in pancreatic progenitor cell proliferation; exogenous FGF10 enhances proliferation of pancreatic progenitor cells and promotes the expression of HES1, a downstream target of notch signaling [80]. Fgf10-deficient mice exhibit reduced proliferation of pancreatic epithelial progenitor cells and display pancreatic hypoplasia [81]. In contrast, overexpression of Fgf10 leads to pancreatic hyperplasia, decreased differentiation of endocrine progenitor cells, and increased progenitor cell numbers [82].

Inhibition of Notch signaling following induction of the PDX $1^{+} / \mathrm{NKX} 6.1^{+}$progenitors leads to the generation of $\mathrm{NGN}^{+}$endocrine progenitors. The transcription factor NGN3 plays an important role at this stage as impaired Notch receptor activation or signaling upregulates NGN3 expression, resulting in premature endocrine cell differentiation. NGN3 is expressed early in the specification of the pancreatic endocrine lineage [83]. Null mutations in NGN3 are associated with neonatal diabetes and blocking of $\beta$-cell differentiation [83], as well as complete loss of all types of pancreatic endocrine cells in Ngn3-deficient mice [84]. Inhibition of BMP and TGF- $\beta /$ Activin A/nodal is required for efficient endocrine development [57]; blocking these pathways increases insulin expression and total number of cells. Abrogation of BMP signaling seems to be responsible for increased insulin expression, while TGF- $\beta$ /Activin A/nodal inhibition enhances cell numbers [57]. High concentrations of Noggin (to inhibit BMP4) are essential for inducing differentiation, first into PDX $1^{+}$progenitors and then into NGN3-expressing pancreatic endocrine progenitors [67]. Differentiation may progress to the stage of insulin expression even without inhibition of BMP [79]. This can be due in part to the low level of endogenous BMP in iPSC lines used for pancreatic differentiation. It generates insulin-positive cells without requiring inhibition of this pathway. At this stage, expression of NKX6.1 is increased, demonstrating the specification of endocrine pancreas. A significant portion of endodermal chromogranin $\mathrm{A}^{-} / \mathrm{PDX}^{+}$cells also expresses NKX6.1 [11].

\subsubsection{Production of Pancreatic $\beta$-Like Cells from iPSCs}

Immature fetal $\beta$-cells require several weeks to gain responsiveness to glucose [85]; this inability may be due to the lower expression levels of the key $\beta$-cell transcription factors controlling the insulin secretory machinery. For example, expression of transcription factors MAFA, NEUROD1, NKX6.1, and PDX1 in the islets of neonatal rats is lower prior to that in islets that have acquired glucose-stimulated insulin secretion (GSIS). MAFA and insulin gene expression reach adult levels by three months [86], concomitant with the ability of $\beta$-cells to sense glucose [85]. MAFA binds to the insulin MAF-responsive element and activates insulin gene expression in response to glucose [87]. Additionally, overexpression of MAFA increases expression of glucokinase, glucose transporter GLUT2, PDX1, NKX6.1, glucagon-like peptide-1 receptor (GLP1R), and pyruvate carboxylase [88], as well as enhancing functional maturation of immature $\beta$-like cells derived from PSCs (for more details refer to [89]).

The differentiation of the endocrine progenitors into $\beta$-like cells is promoted by vitamin E, T3, betacellulin, heparin, ALK5 inhibitors, AXL receptor tyrosine kinase inhibitors, exendin- 4 , hepatocyte growth factor (HGF), insulin-like growth factor 1 (IGF-1), and N-acetyl cysteine, which induce the expression of MAFA [9,14,53,54,67,90,91]. Inclusion of T3 during the last stages of differentiation increases the proportion of cells co-expressing NKX6.1, PDX1, insulin, and NEUROD1, likely through increasing MAFA and NGN3 expression. 


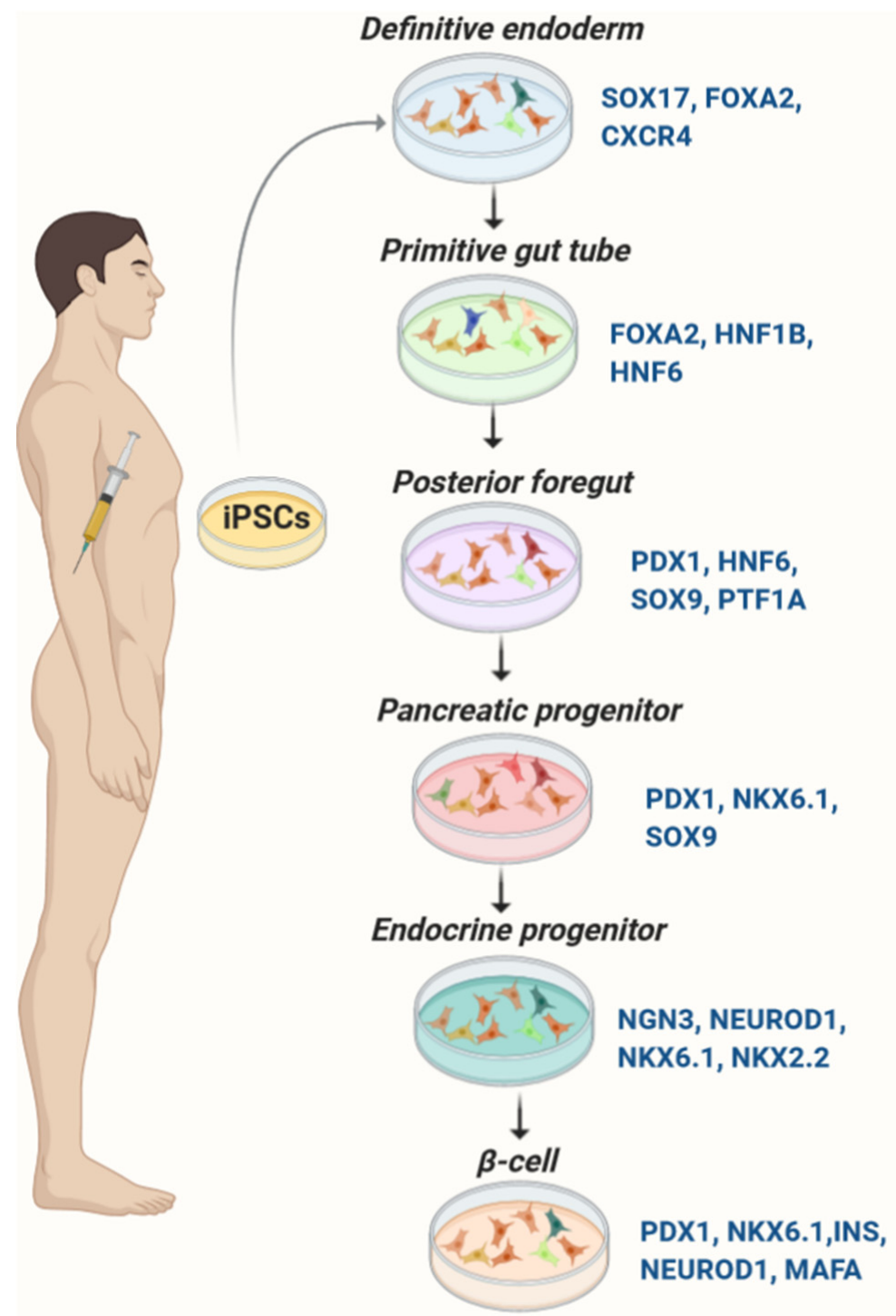

Figure 1. Differentiation of pancreatic $\beta$-cells from iPSCs. Expression of the key transcription factors is monitored for evaluation of the consecutive stages of differentiation.

Using step-wise differentiation protocols, several groups have successfully generated glucose-responsive iPSC-derived $\beta$-like cells. Glucose sensing and the amount of secreted insulin are, however, not equivalent to that observed in cadaveric human islets in vitro. The insulin secretion capacity of iPSC-derived $\beta$-cells is qualitatively similar to that of cadaveric islets in terms of the ability to regulate de- and re-polarization of the plasma membrane in response to $\mathrm{KCl}$ or altering ATP-sensitive potassium channel ( $\mathrm{K}_{\text {ATP }}$ channel) activity $[90,92,93]$. iPSC-derived pancreatic endodermal cells also exhibit a $\mathrm{Ca}^{2+}$ response and increased insulin secretion following glucose stimulation [11]. Compared to adult human primary $\beta$-cells, this glucose-stimulated $\mathrm{Ca}^{2+}$ increase is heterogeneous, demonstrating both oscillatory and biphasic kinetics [11]. Plasma membrane depolarization by $\mathrm{KCl}$ causes an immediate and transient $\mathrm{Ca}^{2+}$ increase in iPSC-derived $\beta$-cells [11]. These observations indicate that $\mathrm{K}_{\mathrm{ATP}}$ channels and voltage-gated $\mathrm{Ca}^{2+}$ channels in these $\beta$-like cells are functional.

Low levels of secretion of insulin in response to glucose may be due to constraints of metabolism. The capacity of iPSC-derived $\beta$-cells to transport glucose across the plasma membrane is similar to that in cadaveric islets [92]. iPSC-derived $\beta$-cells also demonstrate an increase in oxygen consumption rate (OCR) after a glucose challenge but they are not able to maintain fully uncoupled OCR, and rapidly lose electron transport chain activity [92]. Differentiated $\beta$-like cells 
contain equal or even higher amounts of mitochondrial mass per cell compared to cadaveric islets, suggesting that $\beta$-like cells may have metabolically dysfunctional mitochondria or that there is an insufficient metabolic substrate supply to sustain the electron transport chain during glucose challenge. Accumulation of the early glycolysis-derived metabolites dihydroxyacetone phosphate, glycerol-3-phosphate, and phosphoenolpyruvate is similar in cadaveric islets and iPSC-derived $\beta$-cells [92]; the most striking differences between $\beta$-like cells and cadaveric islets appear in mitochondrial metabolite pools owing to anaplerotic generation of oxaloacetate. The total phosphoenolpyruvate metabolite pool derived from glycolysis and oxaloacetate is much smaller in $\beta$-like cells than in cadaveric islets [92]. GSIS in iPSC-derived $\beta$-like cells is limited by the enzymatic conversion of glyceraldehyde-3-phosphate to 3-phosphoglycerate, which is catalyzed by glyceraldehyde 3-phosphate dehydrogenase (GAPDH) and phosphoglycerate kinase (PGK1). Although there is no difference in protein levels of GAPDH and PGK1, the activities of both enzymes are reduced in $\beta$-like cells [92].

Estrogen-related receptor $\gamma(\mathrm{ERR} \gamma)$ has been suggested as a master regulator of $\beta$-cell maturation [94]. Postnatal induction of ERR $\gamma$ expression promotes mitochondrial oxidative phosphorylation, electron transport chain activity, and ATP production, all of which are essential for GSIS [94]. Overexpression of ERR $\gamma$ in iPSC-derived $\beta$-like cells triggers a metabolic transformation that facilities GSIS in vitro. These differentiated cells reduce blood glucose levels when transplanted into diabetic mice [94]. Additionally, testosterone has been shown to promote the differentiation efficiency of iPSC-derived $\beta$-like cells by increasing expression of pancreatic $\beta$-cell progenitor master genes [95].

Pretreatment of mesenchymal stromal cells with epigenetic modifiers has been shown to increase expression of insulin, GLUT2, glucokinase, as well as the transcription factors PDX1, NKX6.1, and MAFA [96]. The differentiated $\beta$-like cells are glucose-responsive and show a significant decrease in global DNA methylation level [96]. In addition, ROCKII inhibition at the pancreatic progenitor stage promotes the maturation of iPSC-derived $\beta$-cells by increasing the percentage of INS ${ }^{+}$cells at the end of differentiation. Inhibition of ROCKII enhances NKX6.1, INS, UCN3, MAFA and G6PC2 expression levels, improves glucose sensitivity, as well as reduces expression of cell cycle and focal adhesion genes, conferring robustness to functionally mature iPSC-derived $\beta$-cells [97].

Using the differentiation protocol described by Ameri et al. [98], our group has successfully generated $\beta$-like cells from iPSC lines derived from patients with T2D. Using a six-stage protocol, the iPSCs are driven from a single layer cell in the undifferentiated state through all developmental stages, finally forming clusters of $\beta$-like cells at day 35 (Figure $2 \mathrm{~A}-\mathrm{G}$ ). To confirm $\beta$-cell differentiation, insulin gene expression was determined at different time points of the differentiation, showing a marked increase from day 29 and onward (Figure $2 \mathrm{H}$ ). Furthermore, the clusters exhibited strong immunostaining for insulin and PDX1, but much less so for glucagon (Figure 2I-L).

Although in vitro iPSC differentiation protocols do not generate pure populations of $\beta$-like cells, some cell surface markers can be used to isolate pure and functional iPSC-derived $\beta$-cells and re-aggregate them before encapsulation for transplantation. Cell surface markers SUSD2, CD200, and CD318 identify endocrine progenitors (NGN3 ${ }^{+}$cells) [64]. Glycoprotein 2 (GP2), CD142, and CD24, have been shown to identify $\beta$-cell precursors [99-101]. Cell surface marker CD49a identifies $\beta$-like cells [102]. Currently, the final step of $\beta$-cell maturation is accomplished in vivo after transplantation into mammalian hosts [54]. The molecular mechanisms of in vivo terminal differentiation are not fully understood. Different potential scenarios, like the involvement of neuronal signals [103], circulating factors [104,105], and the impact of three dimensional (3D) niches [106] have, however, been implicated. 


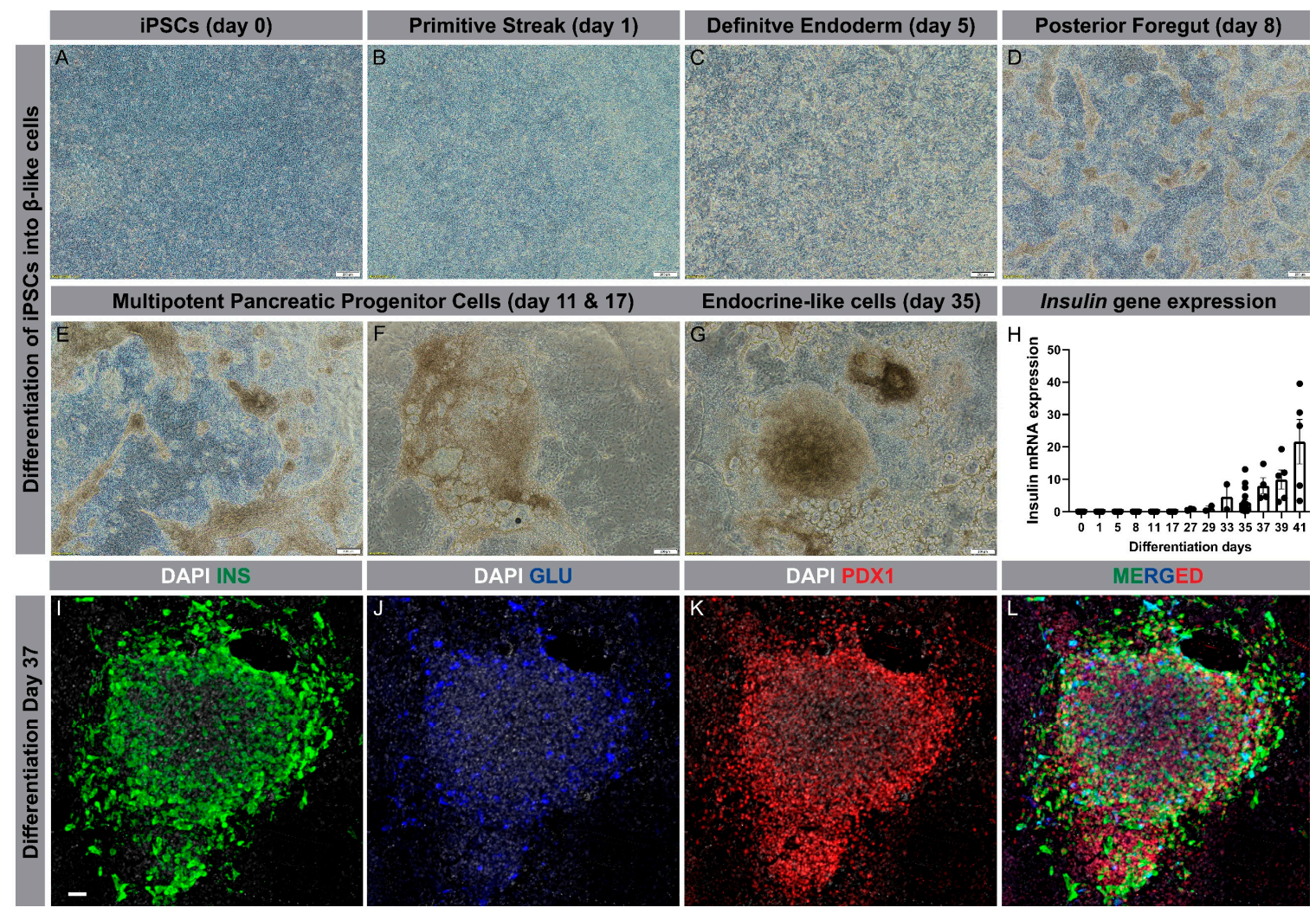

Figure 2. Differentiation of human iPSCs into $\beta$-like cells. (A-G): Progression through different developmental stages during differentiation of iPSCs into $\beta$-like cells (scale bar is $200 \mu \mathrm{m}$ ); (H): Insulin gene expression through the course of differentiation, ranging from day 0 to day 41; (I-L): Condensed cluster of differentiated cells at day 37 displaying protein expression of insulin (green), glucagon (blue), and PDX1 (red); nucleus (grey) (Scale bar is $50 \mu \mathrm{m}$ ).

\subsubsection{Impact of Cellular Microenvironment in Differentiation of iPSC-Derived $\beta$-Cells}

Pancreatic islet architecture with intra-islet cell-cell communication between $\beta$-cells and other endocrine cell types are essential for $\beta$-cell functionality and glucose responsiveness. During islet development, for proper $\beta$-cell lineage specification, differentiation and maturation, intact cell-cell (via intercellular adherents junctions: cadherins, connexins, and nectins) and cell-matrix (via mechanical cues through extracellular matrix (ECM) stiffness, topography, fluid shear forces, and geometry) interactions are crucial for coordinating and supporting cells [107-112]. The pancreas is considered a soft organ based on its ECM composition. This favors a low range of physiological stiffness for $\beta$-cell development in vivo, which is contrary to the standard 2D monolayer differentiation culture systems, possessing a much higher stiffness than the native islet niches [111]. Observations from culture of human islets reveal that soft substrates maintain islet cells coalescence and organization, while stronger extracellular-cell interactions in stiffer culture conditions cause cells to scatter and lose their function [113].

Success in producing and maintaining functional $\beta$-cells in vitro greatly depends on the ability to recapitulate the native islet $3 \mathrm{D}$ microenvironment, with its spatial, chemical and mechanical attributes. The 3D microenvironment of the islet niche is composed of multiple layers of interconnected cells, nerve fibers, blood vessels, and ECM molecules (such as fibronectin, vitronectin, laminins, and collagens). All together, they serve to generate synchronized insulin secretion [112,114-119]. Vascular endothelial cells release soluble factors that play a crucial role for endocrine cell development and proper glucose-responsive insulin release from $\beta$-cells [120]. Furthermore, by providing a basal membrane, vascular endothelial cells also are responsible for cell-cell interactions between $\alpha$ - and $\beta$-cells [120]. 
Alterations of the ECM are sensed by $\beta$-cell mechanosensors (such as primary cilia, ion channels, integrins, glycocalyx, and cadherins), which transduce signaling cascades intracellularly. Thus, cytoskeletal dynamics and formation of integrin adhesion complexes are brought into motion $[107,110]$. These signals of mechanotransduction modify cellular programs by altering the nuclear architecture, gene transcription via mechanosensitive transcription factors (YAP/TAZ, TCF/LEF, etc.), mitochondrial dynamics, and the RhoA/ROCK pathway $[107,121]$. Aggregated (confined) cell clusters exposed to laminin are more robust in producing pancreatic progenitors expressing PDX1 and NKX6.1, as well as NGN3 ${ }^{+}$endocrine progenitors, rather than spread out loose cells, reflecting a more ductal phenotype [122]. This phenomenon is accompanied by the appearance of reduced formation of stress fibers and mediated by actin polymerization and YAP-Notch mechanosignaling [122].

To provide 3D cell-cell interactions, suspension/aggregate/spinner flask culture systems have been developed to induce formation of islet-like organoids, which further promote formation of glucose-responsive $\beta$-cells from stem cells $[78,102,123,124]$. By use of such a system, monohormonal and glucose-responsive $\beta$-like cells were produced that show key features of bona fide $\beta$-cells, like high mRNA levels of the transcription factor MAFA and $\beta$-cell ultrastructure [90]. $\beta$-cells generated in 3D culture system and primary adult islets show similar responses to multiple sequential high glucose challenges and depolarization with $\mathrm{KCl}$. Notably, some iPSC-derived $\beta$-like cells exhibit insulin content and secretion at levels similar to that of primary islets; both the entire population, as well as individual iPSC-derived $\beta$-like cells, show $\mathrm{Ca}^{2+}$ fluxes similar to those in primary human islet cells [90].

Although 3D culture systems are considered superior to 2D systems, recently, differential actin cytoskeleton states (polymerized vs. depolymerized), cell adhesion intensity to the surface of culture plates, and substrate stiffness have been shown to control the timing of NEUROG3, and NKX6.1 expression, hereby inducing pancreatic endocrine lineage [125]. A 2D planar differentiation protocol was established by including a chemical compound (latrunculin A), which specifically alters cytoskeletal dynamics [125]. This enhances the differentiation efficiency and functionality of ESCs, as well as iPSC-derived $\beta$-like cells. This demonstrates that use of 3D culturing systems, in order to produce glucose-responsive iPSC-derived $\beta$-like cells, can be substituted by manipulating cell-biomaterial interactions with an efficient 2D planar protocol, hereby opening new opportunities to improve differentiation outcomes [125].

\subsection{6. iPSC-Derived $\beta$-Like Cells: Treatment of Diabetes and Disease-in-a-Dish Models}

Generation of $\beta$-cells from PSCs holds great promise in the treatment of diabetes. In addition, diabetes patient-derived iPSCs could serve as experimental models to investigate disease mechanisms. There are more than 400 genetic signals associated with T2D and fasting glucose [126]. Many of these "diabetes risk loci" may perturb $\beta$-cell number, and deregulate proinsulin conversion and insulin secretion (for details refer to [127]). iPSCs from patients with either T1D [128] or T2D [129] have been established. We also have generated several iPSC lines from patients carrying T2D risk alleles and successfully differentiated $\beta$-like cells from these iPSC lines. For therapeutic purposes, generating $\beta$-cells from a patient's own iPSCs would potentially also limit immune reaction and hence the need for immune suppressants (at least in T2D). Such drugs have various side effects, which may interfere with insulin action and sensitivity, for instance, steroids. However, immunogenicity of iPSCs characterized by T-cell infiltration and massive necrosis after transplantation in syngeneic recipients has been reported [130]; this can be due in part to aberrant antigens resulting from long-term maintenance or immunogenic alteration due to rapid in vitro differentiation. Although many differentiation protocols have been established on feeder-free culture systems, some protocols still use numerous animal-derived products that may exert unknown effects on cells, increase immune reactions and risks of graft rejection (reviewed in [131]).

Encapsulation of iPSC-derived $\beta$-cells could solve issues with immunity: a flat-sheet macroencapsulation device, to graft the iPSC-derived pancreatic endoderm cells under the skin of immune-compromised mice, increases circulating C-peptide levels in response to glucose 
administration [11]; both fasting and glucose-stimulated C-peptide levels continue to rise in response to glucose after 18 weeks post-implantation, indicating that the maturation of iPSC-derived $\beta$-cells is furthered over time in vivo [11]. Typical grafts contain multiple cell clusters individually expressing insulin, glucagon, somatostatin, and ghrelin in a heterogeneous cellular architecture, reminiscent of either fetal or more or less immature pancreatic islets [11]. Encapsulation of pancreatic endocrine progenitors enhances the rate of hormone-positive and insulin-expressing cells co-expressing key $\beta$-cell markers and therefore promotes the differentiation outcome. Encapsulation at the first differentiation stages improves early differentiation signals, whereas encapsulation at a later differentiation stage improves expression of hormones and factors involved in hormone synthesis and secretion [9]. Additionally, transplantation of iPSC-derived pancreatic endodermal cells in STZ-induced diabetic mice increases glucose clearance for several weeks after treatment, while removal of the implants renders animals strongly hyperglycemic [11]. Transplantation of iPSC-induced $\beta$-like cells under the kidney capsule of immunodeficient diabetic mice normalizes blood glucose levels after two weeks [90]. In addition, analysis of C-peptide and glucagon staining reveals that these $\beta$-cells remain monohormonal after transplantation [90].

Table 1. Overview of protocols used for differentiation of pancreatic $\beta$-like cells from human iPSCs.

\begin{tabular}{|c|c|c|c|c|}
\hline iPSC Source & Protocol & In Vivo/Vitro Efficacy & Stage/Day & Ref. \\
\hline Human iPSCs & $\begin{array}{c}\text { Days 1-3: GDF8 and GSK3 } \beta \text { inh. Days 4-5: FGF7 } \\
\text { and VitC. Days 6-7: FGF7, VitC, } 1 \mu \text { M RA, SANT, } \\
\text { TPB, LDN. Days 8-10: FGF7, VitC, } 100 \text { nM RA, } \\
\text { SANT, TPB, LDN. Days 11-13: 50 nM RA, T3, } \\
\text { SANT, ALK5 inh, LDN. Days 14-21/29: T3, ALK5 } \\
\text { inh, LDN, } \gamma \text {-secretase inh. Days 21/29-28/36: T3, } \\
\text { ALK5 inh, AXL inh, N-Acetylcysteine }\end{array}$ & $\begin{array}{c}\uparrow \text { GSIS and plasma human } \\
\text { c-peptide levels after } \\
\text { transplantation in mice }\end{array}$ & $7 / 28-36$ & [78] \\
\hline Human iPSCs & $\begin{array}{l}\text { Days 1-2: Activin A, CHIR99021. Day 3: No feed. } \\
\text { Day 4: KGF. Day5: No feed. Day 6: KGF. Days } \\
\text { 7-8: LDN, KGF, SANT, Y-27632, RA, PdBU. Days } \\
\text { 9-14: KGF, SANT, Y-27632, RA, Activin A. Days } \\
\text { 15-22: Betacellulin, RA, T3, ALK5 inh, SANT, } \\
\text { Heparin, } \gamma \text {-secretase inh. Days 22-29/36: T3, } \\
\text { ALK5 inh }\end{array}$ & $\uparrow$ GSIS in vivo and in vitro & $6 / 29-36$ & [132] \\
\hline Human iPSCs & $\begin{array}{c}\text { Days 1-2: Activin A, CHIR99021. Days 2-4: } \\
\text { Activin A. Days 4-7: KGF. Days 7-9: KGF, } \\
\text { SANT1, RA, LDN (only Day 7), PdBU. Days 9-14: } \\
\text { KGF, SANT, RA. Days 14-18: RA, SANT1, ITS-X, } \\
\text { VitC, Heparin, T3, ALK5 inh, Betacellulin, } \\
\text {--secretase inh. Days 18-21: RA, ITS-X, VitC, } \\
\text { Heparin, T3, ALK5 inh, Betacellulin, } \gamma \text {-secretase } \\
\text { inh. Days 21-35: ALK5 inh, T3 }\end{array}$ & $\uparrow$ GSIS in vitro & $6 / 35$ & [92] \\
\hline Human iPSCs & $\begin{array}{l}\text { Days 1-2: Activin A, Wnt3a, VitC. Days 3-4: } \\
\text { Activin A. Days 5-12: dorsomorphin, RA, } \\
\text { SB431542 (TGFß inh). Days 13-23: Forskolin dex, } \\
\text { ALK5 inh, Nicotinamide, T3. Days 24-27/29: } \\
\text { overexpression of ERR } \gamma\end{array}$ & $\begin{array}{l}\uparrow \mathrm{KCl} \text { stimulated insulin } \\
\text { secretion without ERR } \gamma \\
\text { overexpression. } \leftrightarrow \mathrm{GSIS} \\
\quad \text { without } \mathrm{ERR} \gamma \\
\text { overexpression. } \uparrow \mathrm{KCl} \text { and } \\
\text { glucose stimulated insulin } \\
\text { secretion after } \mathrm{ERR} \gamma \\
\quad \text { overexpression }\end{array}$ & $3 / 23$ & [94] \\
\hline
\end{tabular}


Table 1. Cont.

\begin{tabular}{|c|c|c|c|c|}
\hline iPSC Source & Protocol & In Vivo/Vitro Efficacy & Stage/Day & Ref. \\
\hline Human iPSCs & $\begin{array}{c}\text { Days 1-3: Activin A, CHIR99021. Days 4-7: KGF. } \\
\text { Days 8-9: KGF, SANT1, RA, LDN, PdBU. Days } \\
\text { 10-15: KGF, SANT, RA. Days 16-23: RA, SANT1, } \\
\text { T3, ALK5 inh, Betacellulin, } \gamma \text {-secretase inh. Days } \\
\text { 18-21: RA, ITS-X, VitC, Heparin, T3, ALK5 inh, } \\
\text { Betacellulin, } \gamma \text {-secretase inh. Days 22-60: } \\
\text { ALK5 inh, T3 }\end{array}$ & $\uparrow$ GSIS in vitro & $6 / 22-60$ & [102] \\
\hline Human iPSCs & $\begin{array}{l}\text { Days 1-2: Activin A, CHIR99021. Days 2-3: } \\
\text { Activin A. Days 4-5: VitC, KGF. Days 6-10: } \\
\text { Insulin, ITS-X, KGF, SANT, RA, LDN, TPB }\end{array}$ & NR & $4 / 10$ & [7] \\
\hline Human iPSCs & $\begin{array}{l}\text { Days 1-3: CHIR99021, GDF8, Activin A, Wnt3A. } \\
\text { Days 4-5: FGF7, VitC. Days 6-10: FGF7, VitC, } \\
\text { RA, TPB, LDN, Noggin, SANT. Days 11-13: RA, } \\
\text { LDN, SANT, ALK5 inh, T3. Days 14-25: LDN, } \\
\text { ALK5 inh, T3, } \gamma \text {-secretase inh, Heparin. Days } \\
\text { 30-45: ALK5 inh, T3, Cyclopamine, AXL inh. }\end{array}$ & NR & $7 / 45$ & [9] \\
\hline Human iPSCs & $\begin{array}{c}\text { Day 0: Wnt3A, Activin A, Y-27632, ITS-X. Day 1: } \\
\text { Activin A, Y-27632, ITS-X. Day 2: ITS-X, KGF, } \\
\text { ALK4 inh, Y-27632. Day 3: ITS-X, KGF, ALK4 inh. } \\
\text { Day 4: KGF. Days 5-7: TTNBP, Noggin, } \\
\text { Cyclopamine, Heregulin. Days 8-12: Noggin, } \\
\text { Heregulin, EGF, KGF, Y-27632 }\end{array}$ & $\begin{array}{l}\uparrow \text { Fasting and } \\
\text { glucose-stimulated human } \\
\text { c-peptide levels in vivo }\end{array}$ & $4 / 12$ & [11] \\
\hline Human iPSCs & $\begin{array}{l}\text { Days 1-3: Activin A, CHIR99021. Days 4-5: } \\
\text { FGF7, VitC. Days 6-7: FGF7, VitC, RA, TPB, } \\
\text { LDN, SANT. Days 8-10: FGF7, VitC, RA, LDN, } \\
\text { SANT, EGE, Nicotinamide. Days 11-14: LDN, } \\
\text { ALK5 inh, Betacellulin, Heparin, RA, ITS-X, GC1, } \\
\text { ZnSO4. Days 14-28: LDN, ALK5 inh, } \\
\text { Betacellulin, Heparin, } \gamma \text {-secretase inh, ITS-X, } \\
\text { GC1, ZnSO4. Days 29-35: ALK5 inh, Heparin, } \\
\text { ITS-X, GC1, ZnSO4, Trolox, JNK inh, Resveratrol, } \\
\text { N-Acetylcysteine, AXL inh }\end{array}$ & $\begin{array}{l}\uparrow \text { GSIS and plasma human } \\
\text { c-peptide levels after } \\
\text { transplantation in mice }\end{array}$ & $7 / 35$ & [133] \\
\hline Human iPSCs & $\begin{array}{l}\text { Days 1-3: Activin A, CHIR99021, Y-27632, } \\
\text { DMSO. Days 3-7: KGF. Days 7-10: KGF, Noggin, } \\
\text { VitC, TTNPB, Cyclopamine. Days 10-14: KGF, } \\
\text { EGF, Nicotinamide, Y-27632, VitC. Days 14-17: } \\
\text { SANT-1, RA, ALK5 inh, LDN, T3, } \gamma \text {-secretase inh, } \\
\text { bFGF, XAV939 (Wnt inh), Y-27632 }\end{array}$ & $\begin{array}{c}\downarrow \text { Fasting blood glucose and } \\
\uparrow \text { plasma human c-peptide } \\
\text { after transplantation into } \\
\text { diabetic mice }\end{array}$ & $5 / 17$ & {$[54]$} \\
\hline Human iPSCs & $\begin{array}{l}\text { Days 1-3: CHIR99021, GDF8. Days 4-5: FGF7, } \\
\text { VitC. Days 6-7: FGF7, VitC, RA, TPB, LDN, } \\
\text { Noggin, SANT, ITS-X. Days 8-10: ITS-X, } \\
\text { Heparin, RA, LDN, SANT, ALK5 inh, T3. Days } \\
\text { 11-13: ITS-X, SANT, LDN, ALK5 inh, T3, RA, } \\
\text { Heparin. Days 14-20: ALK5 inh, T3, LDN, } \\
\text { } \text {-secretase inh. Days 20-27: ALK5 inh, T3, } \\
\text { N-Acetylcysteine, AXL inh. Day 28: Wnt 3/4/5 or } \\
\text { Wnt inhibitor (G007-LK) for 4h. Days 28-30/37: } \\
\text { ALK5 inh, T3, N-Acetylcysteine, AXL inh }\end{array}$ & $\begin{array}{l}\leftrightarrow \text { GSIS } \leftrightarrow \mathrm{KCl} \text { stimulated } \\
\text { insulin secretion }\end{array}$ & $7 / 37$ & [53] \\
\hline Human iPSCs & $\begin{array}{c}\text { Days 0-1: Activin A, B27, CHIR99021. Days 1-3: } \\
\text { B27, Activin A. Days 3-10: B27, RA, } \\
\text { Dorsomorphin, SB431542. Days 10-20: B27, } \\
\text { Forskolin, Repsox, Nicotinamide, Dex, } \\
\text { Testosterone }\end{array}$ & $\begin{array}{c}\leftrightarrow \text { GSIS } \uparrow K C l \text { stimulated } \\
\text { insulin secretion }\end{array}$ & $3 / 20$ & [95] \\
\hline
\end{tabular}


Table 1. Cont.

\begin{tabular}{|c|c|c|c|c|}
\hline iPSC Source & Protocol & In Vivo/Vitro Efficacy & Stage/Day & Ref. \\
\hline Human iPSCs & $\begin{array}{l}\text { Days 1-2: Activin A, 2-ME, CHIR99021. Days 3-5: } \\
\text { Activin A, 2-ME. Days 6-7: 2-ME, Cyclopamine, } \\
\text { FGF10. Days 8-13: Noggin, RA, Cyclopamine, ALK5 } \\
\text { inh, 2-ME. Days 14-15: 2-ME, Noggin, AlLK5 inh, } \\
\text { Indolactam V. Days 16-23: 2-ME, Exendin4, } \\
\text { Nicotinamide, IBMX, Forskolin }\end{array}$ & $\begin{array}{c}\uparrow \text { c-peptide secretion in the } \\
\text { presence of } \mathrm{KCl}, \mathrm{K}_{\mathrm{ATP}} \\
\text { channel blocker, LVDCC and } \\
\text { muscarinic agonists }\end{array}$ & $5 / 23$ & [67] \\
\hline Human iPSCs & $\begin{array}{l}\text { Days 1-2: Activin A, CHIR99021, FGF2, BMP4, 2-ME. } \\
\text { Days 3-4: KSR, Activin A, 2-ME. Days 5-7: FGF7, } \\
\text { ITS-X. Days 8-11: FGF7, ITS-X, SANT-1, LDN, EC23, } \\
\text { Indolactam V. Days 12-14: FGF10, ITS-X, SANT-1, } \\
\text { LDN, EC23, Indolactam V. Days 15-21: EGF, ITS-X, } \\
\text { SANT-1, LDN, EC23, ZnSO4, Indolactam V, RepSox, } \\
\text { Heparin, Nicotinamide, Exendin4, Y-27632, } \\
\gamma \text {-secretase inh. Days 22-31: BMP4, HGF, IGF, ITS-X, } \\
\text { ZnSO4, Indolactam V, RepSox, Heparin, } \\
\text { Nicotinamide, Exendin4, Forskolin }\end{array}$ & $\begin{array}{l}\downarrow \text { Nonfasting blood glucose, } \\
\text { improved glucose tolerance, } \\
\uparrow \text { plasma human c-peptide } \\
\text { after transplantation into } \\
\text { diabetic mice }\end{array}$ & $6 / 31$ & [14] \\
\hline Human iPSCs & $\begin{array}{l}\text { Days 1-2: Activin A, CHIR99021. Days 2-4: Activin } \\
\text { A. Days 4-7: KGF. Days 7-9: KGF, SANT1, RA, LDN } \\
\text { (only Day 7), PdBU. Days 9-14: KGF, SANT, RA. } \\
\text { Days 14-18: RA, SANT1, ITS-X, VitC, Heparin, T3, } \\
\text { ALK5 inh, Betacellulin, } \gamma \text {-secretase inh. Days 18-21: } \\
\text { RA, ITS-X, VitC, Heparin, T3, ALK5 inh, Betacellulin, } \\
\gamma \text {-secretase inh. Days 21-35: ALK5 inh, T3 }\end{array}$ & $\begin{array}{l}\uparrow \text { GSIS both in vitro and } \\
\text { in vivo }\end{array}$ & $6 / 35$ & [90] \\
\hline Human iPSCs & $\begin{array}{l}\text { Days 1-5: Activin A, Wnt3a. Days 5-7: KGF, VitC, } \\
\text { Y27632. Days 7-8: KGF, VitC. Days 8-12: SANT-1, } \\
\text { RA, Noggin, TPB, VitC, KGF. Days 12-16: ALK5 inh, } \\
\quad \text { Noggin, GLP-1, SANT-1, RA, } \gamma \text {-secretase inh, } \\
\text { Heparin, T3. Days 16-17: ALK5 inh, Noggin, GLP-1, } \\
\quad \text {-secretase inh, Heparin, T3. Days 17-27: } \\
\text { Nicotinamide, IGF-1, GLP-1, ALK5 inh, T3, Heparin }\end{array}$ & $\begin{array}{l}\uparrow \text { GSIS and } \mathrm{KCl} \text { stimulated } \\
\text { insulin secretion both } \\
\text { in vivo and in vitro }\end{array}$ & $5 / 27$ & [91] \\
\hline
\end{tabular}

PdbU, phorbol 12,13-dibutyrate; TTNPB, tetrahydro tetramethyl naphthalenyl propenyl benzoic acid; KSR, knockout serum replacement; KGF, keratinocyte growth factor; ITS-X, insulin-transferrin-selenium-ethanolamine; LVDCC, L-type voltage-dependent $\mathrm{Ca}^{2+}$ channel; RA, retinoic acid; Dex, dexamethasone; HGF, hepatocyte growth factor; GLP-1, glucagon-like peptide-1; IGF-1, insulin-like growth factor 1; ALK inh, activin receptor-like kinase inhibitor; TPB, PKC activator; T3, triiodothyronine; GC1, thyroid hormone receptor- $\beta$ agonist; AXL inh, receptor tyrosine kinase inhibitor; 2-ME, 2-Mercaptoethanol; IBMX, isobutylmethylxanthin; BMP4, bone morphogenetic protein 4; GSIS, glucose stimulated insulin secretion; NR, Not reported; $\uparrow$ increased, $\downarrow$ decreased, $\leftrightarrow$ no effect.

\section{4. iPSC-Derived Insulin-Responsive Cells and Insulin Resistance}

\subsection{Insulin Resistance}

Insulin resistance, a key component of T2D pathophysiology is defined as a state with decreased metabolic actions of insulin in target tissues, namely liver, skeletal muscle, and adipose tissue [2]. Rare defects in the insulin receptor reduce insulin sensitivity, while the more frequent post-receptor perturbations reduce its effects [2]. Environmental factors associated with physical inactivity and obesity account for insulin resistance in the great majority of individuals.

This notwithstanding, longitudinal studies have shown that insulin resistance is also a heritable trait and develops in people at risk for T2D many years before glucose intolerance $[134,135]$. As with potential $\beta$-cell dysfunction, a significant proportion of the genetic variants associated with T2D are likely to be implicated in target tissue dysfunction and hence insulin resistance [126]. For this reason, and others, iPSCs derived from insulin-resistant patients are a unique tool to identify molecular mechanisms of this metabolic dysfunction. It also allows testing of drugs and development of cell-based therapies. Indeed, all insulin target cells, such as skeletal myotubes, adipocytes, and hepatocytes can be generated from patient-specific iPSCs. By carrying the same genetic signature as T2D patients, they may help to identify the genetic factors involved in the disease progression. 


\section{2. iPSC-Derived Hepatocytes}

\subsubsection{Development of the Liver}

Hepatocytes, the principal liver cell type, are derived from embryonic endoderm [136]. Liver-specific transcriptional factors and external signaling events originating from the cardiac mesoderm result in differentiation of the endoderm to hepatoblasts, then to the liver bud, and eventually a fully formed liver. FOXA proteins regulate almost all liver-specific genes [137]. Cardiogenic mesoderm, by expressing different FGF proteins, provides critical extracellular signals to liver progenitor cells $[136,137]$. The septum transversum mesenchyme also expresses BMP2 and BMP4 and plays a role before and during the induction of hepatoblasts within the endoderm. Hematopoietically expressed and Prospero-related homeobox factors, HEX and PROX1, through encoding transcriptional regulatory proteins, as well as ECM proteins that interact with $\beta 1$ integrin receptors, play an important role in liver bud development [136].

\subsubsection{Differentiation of iPSCs into Hepatocytes}

A combination of growth factors and small molecules is used for differentiating hepatic developmental stages from definitive endoderm to immature hepatocytes (hepatic progenitors) and finally mature hepatocytes (Table 3) $[138,139]$.

\section{Differentiation of Definitive Endoderm and Immature Hepatocytes}

For differentiation of definitive endoderm, various signaling pathways controlling the early cell fate decisions of pluripotent stem cells, such as those involving Wnt, Activin, BMP, and FGF are activated. Following generation of endodermal cells from iPSCs, hepatoblasts are formed. To this end, HGF or KGF is added. At this stage, differentiated hepatoblasts display expression of FOXA1, FOXA2, CCAAT enhancer-binding protein alpha $(\mathrm{CEBP} \alpha)$, peroxisome proliferator-activated receptor alpha (PPAR $\alpha$ ), alpha-fetoprotein (AFP), and cytokeratin (KRT)-18 and -19 [72,140-143]. After treatment with HGF, cells begin to express the adult isoforms of HNF1 $\alpha$ and HNF4 $\alpha$, liver X receptor (LXR), ATP-binding cassette transporter A1 (ABCA1), alpha-1-antitrypsin (A1AT), albumin, as well as liver-specific microRNAs miR122, miR148a, and miR194 [72]. In addition, expression of retinoid X receptor (RXR) and vascular endothelial growth factor receptor (VEGFR) is increased and then declines progressively towards the final stages of differentiation [72].

Table 2. Small molecules used for differentiation of insulin/glucose-responsive cells from iPSCs.

\begin{tabular}{|c|c|c|}
\hline Molecule & Function & Ref. \\
\hline Activin A & Member of the TGF- $\beta$ family; induces DE lineage from stem cells & {$[144]$} \\
\hline ALK5iII/RepSox & $\begin{array}{l}\text { TGFßR-1/ALK5 inhibitor, upregulates expression of UCN3, MAFA, } \\
\text { NKX6.1, and PDX1; induces hepatic and myocyte differentiation }\end{array}$ & {$[8,79]$} \\
\hline B27 & $\begin{array}{l}\text { Supports cell growth, viability and induction of endoderm lineage. } \\
\text { Promotes } \beta \text {-cell differentiation, maturation, and increases the number of } \\
\text { insulin }{ }^{+} \text {cells. Also induces hepatocyte differentiation }\end{array}$ & {$[98,145,146]$} \\
\hline Betacellulin & $\begin{array}{l}\text { EGF receptor ligand. Maintains expression of NKX6.1 and PDX1 in } \\
\text { endocrine progenitors. Aids in inducing MAFA expression in } \beta \text {-like cells }\end{array}$ & {$[147]$} \\
\hline $\mathrm{bFGF} / \mathrm{FGF} 2$ & $\begin{array}{l}\text { Suppresses SHH signaling and initiates pancreatic differentiation by } \\
\text { inducing PDX1 expression. Also induces hepatoblasts and myogenic } \\
\text { differentiation by deriving mesoderm lineage }\end{array}$ & {$[63,72,148]$} \\
\hline CHIR99021 & $\begin{array}{l}\text { Inhibits GSK } 3 \alpha / \beta \text { and promotes Wnt signaling for efficient induction of } \\
\text { DE lineage }\end{array}$ & {$[79,149]$} \\
\hline Cyclopamine & Blocks SHH signaling. Induces PE lineage and promotes PDX1 expression & {$[150,151]$} \\
\hline Db-cAMP & Nerve growth factor. Induces expression of MAFA and insulin & [152] \\
\hline
\end{tabular}


Table 2. Cont

\begin{tabular}{|c|c|c|}
\hline Molecule & Function & Ref. \\
\hline Dexamethasone & $\begin{array}{c}\text { Enhances } \beta \text {-like cell differentiation and proliferation. Increases the } \\
\text { number of insulin }{ }^{+} \text {cells at the end of differentiation. Aids maturation of } \\
\text { hepatocytes and adipocytes }\end{array}$ & {$[72,79,153]$} \\
\hline DMSO & $\begin{array}{l}\text { Can be used in combination with activin A to stimulate the process of } \\
\text { DE induction }\end{array}$ & [154] \\
\hline Dorsomorphin & $\begin{array}{l}\text { BMP inhibitor, enhances PDX } 1^{+} \text {expression in the PE stage. Aids in } \\
\text { maturing } \beta \text {-like cells }\end{array}$ & {$[79,152]$} \\
\hline EC23 & Synthetic retinoic acid receptor agonist, used for the formation of PE & [14] \\
\hline EGF & $\begin{array}{l}\text { Stimulates cell growth, differentiation and maturation of several cell types } \\
\text { including hepatocytes, myocytes and } \beta \text {-cells. Expands the PDX } 1^{+} \text {PPs } \\
\text { and promotes endocrine cell fate }\end{array}$ & [155] \\
\hline Exendin-4 & $\begin{array}{l}\text { Analog of GLP1. Promotes } \beta \text {-like cell maturation by enhancing the } \\
\text { expression of GCK, GLUT2, and NEUROD1 }\end{array}$ & [156] \\
\hline Fasudil & RhoA/Rho kinase (Rock) inhibitor; promotes DE & [157] \\
\hline FGF10 & Aids in the induction of DE and enhances the characteristic markers of PE & [158] \\
\hline FGF4 & At high concentration promotes endodermal cell fate and expansion & [65] \\
\hline FGF7 & $\begin{array}{c}\text { Induces expression of PDX1, PTF1A, and HLXB9. Aids in producing 3D } \\
\text { cellular clusters }\end{array}$ & [159] \\
\hline Forskolin & $\begin{array}{c}\text { Increases the levels of cAMP. Derives differentiation and maturation of } \\
\text { hepatocytes, myocytes and } \beta \text {-cells. Is required for priming } \beta \text {-cell } \\
\text { differentiation and insulin expression }\end{array}$ & {$[8,79,160]$} \\
\hline GDF8 & Belongs to the TGF $\beta$ family and induces DE & [78] \\
\hline Glutamine & $\begin{array}{l}\text { Induces myocytes characteristics while differentiating. Induces hepatic } \\
\text { specification from DE lineage }\end{array}$ & {$[140,161]$} \\
\hline Heparin & $\begin{array}{l}\text { Co-factor for FGF2. Enhances generation of endocrine cells and mature } \\
\beta \text {-like cells from PDX } 1^{+} \mathrm{PPs}\end{array}$ & [133] \\
\hline Heregulin & Member of the EGF family used in deriving PE cells & [11] \\
\hline HGF & Matures $\beta$-like cells, hepatocytes, and myocytes & {$[151,162]$} \\
\hline Hydrocortisone & Matures hepatocytes while differentiating from DE lineage & [163] \\
\hline IBMX & $\begin{array}{c}\text { Phosphodiesterene inhibitor and an adenosine receptor antagonist. } \\
\text { Induces adipocyte differentiation and maturation. Enhances insulin } \\
\text { expression and proportion of differentiating } \beta \text {-like cells }\end{array}$ & [164] \\
\hline IDE1/2 & Activator of the SMAD2/3 pathway and induces DE lineage & [165] \\
\hline IGF-1 & Induces myogenic as well as $\beta$-like cell differentiation and maturation & [166] \\
\hline Indolactam V & Activator of the PKC pathway; induces PDX ${ }^{+}$PPs & [167] \\
\hline ITS-X & $\begin{array}{l}\text { Supports differentiation and maturation of hepatocytes and adipocytes. } \\
\text { Also aids in formation of PPs to insulin-producing } \beta \text {-like cells }\end{array}$ & {$[72,168,169]$} \\
\hline KGF/FGF7 & $\begin{array}{c}\text { Generates PDX } 1^{+} \text {PPs and PDX1 } 1^{+} / \mathrm{NKX} 6.1^{+} \text {endocrine progenitor cells. } \\
\text { Drives hepatoblasts from foregut endoderm cells }\end{array}$ & {$[8,170]$} \\
\hline LDN & $\begin{array}{l}\text { BMP type } 1 \text { receptor inhibitor. Promotes PDX } 1^{+} \text {PPs and maturation of } \\
\quad \beta \text {-like cells }\end{array}$ & [171] \\
\hline LY294002 & Inhibits GSK3- $\beta$ and PI3K activity for efficient induction of DE lineage & [144] \\
\hline Lysophosphatidic acid & $\begin{array}{l}\text { Acts through } G \text { protein-coupled receptors. Induces hepatoblast } \\
\text { differentiation and expansion }\end{array}$ & [8] \\
\hline $\mathrm{N}$-acetyl cysteine & Functions as an antioxidant. Enhances expression of MAFA & {$[145,172]$} \\
\hline NECA & Activates adenosine signaling and promotes $\beta$-like cell proliferation & [164] \\
\hline Nicotinamide & $\begin{array}{c}\text { A poly (ADP-ribose) synthetase inhibitor; promotes expression of PDX1 } \\
\text { up to the later stages in } \beta \text { cell differentiation process. Crucial for } \\
\text { hepatocyte differentiation, proliferation and maturation }\end{array}$ & {$[147,173]$} \\
\hline Noggin & $\begin{array}{l}\text { BMP inhibitor, induces PDX1 } 1^{+} \text {PPs and } \mathrm{NGN3}^{+} \text {endocrine progenitors by } \\
\text { suppressing hepatic lineage differentiation }\end{array}$ & [67] \\
\hline
\end{tabular}


Table 2. Cont.

\begin{tabular}{|c|c|c|}
\hline Molecule & Function & Ref. \\
\hline Oncostatin M & $\begin{array}{c}\text { Member of IL- } 6 \text { cytokine family and is crucial for liver development in } \\
\text { the final stage of hepatocyte differentiation }\end{array}$ & [174] \\
\hline PdBU & $\begin{array}{l}\text { A phorbol ester, acts as an activator of PKC and is used in promoting } \\
\text { pancreatic differentiation }\end{array}$ & [90] \\
\hline Pioglitazone & $\begin{array}{l}\text { An antidiabetic drug, induces lipid-accumulating } \\
\text { adipocyte differentiation }\end{array}$ & [175] \\
\hline Plasmanate & A plasma protein fraction used for inducing adipocyte differentiation & [176] \\
\hline Resveratrol & $\begin{array}{c}\text { A stilbenoid polyphenol, enhances the expression of key } \beta \text {-cell } \\
\text { maturation genes }\end{array}$ & [177] \\
\hline Retinoic acid & $\begin{array}{l}\text { Crucial for generating NGN3 }{ }^{+} \text {endocrine progenitors and for the } \beta \text {-cell } \\
\text { specification. Differentiates hepatoblasts into cholangiocyte progenitors. } \\
\text { Depending on its concentration and stage administration, it can have a } \\
\text { variable but crucial effect on adipocyte differentiation }\end{array}$ & {$[72,178-180]$} \\
\hline RG108 & $\begin{array}{l}\text { Inhibits DNA methyltransferase, Stimulate reprogramming from somatic } \\
\text { cells to iPSCs }\end{array}$ & [39] \\
\hline RKI-1447 & $\begin{array}{l}\text { Rho-kinase inhibitor, induces DE lineage and aids differentiation into } \\
\qquad P D X 1^{+} \text {PPs }\end{array}$ & [157] \\
\hline Rosiglitazone & $\begin{array}{l}\text { An antidiabetic drug, derives adipogenesis by enhancing the expression } \\
\text { of PPAR } \gamma \text { and C/EBP- } \alpha \text { as well as activation of MAPK and PI3K pathways }\end{array}$ & [181] \\
\hline SANT-1 & $\begin{array}{l}\text { SHH signaling inhibitor, enhances formation of PE and } \\
\text { PDX1 } 1^{+} \text {NKX } 6.1^{+} \text {PPs }\end{array}$ & [74] \\
\hline SB431542 & $\begin{array}{c}\text { TGF- } \beta \text { receptor inhibitor, enhances number of NKX6.1 } 1^{+} \mathrm{NGN}^{+} \\
\text {endocrine progenitors }\end{array}$ & [145] \\
\hline Sodium Butyrate & Inhibits histone deacetylation and aids in DE lineage induction & [182] \\
\hline Sodium cromoglicate & Enhances $\mathrm{NGN3}^{+}$endocrine precursors and insulin ${ }^{+}$cells & [183] \\
\hline Sphingosine-1-phosphate & $\begin{array}{c}\text { A signaling sphingolipid metabolite, aids hepatoblast expansion } \\
\text { during differentiation }\end{array}$ & [8] \\
\hline Stauprimide & $\begin{array}{l}\text { Belongs to the family of indolocarbazoles, derives DE lineage by } \\
\text { downregulating c-Myc expression }\end{array}$ & [184] \\
\hline Triiodothyronine (T3) & $\begin{array}{l}\text { Induces MAFA expression and generates mono-hormonal insulin }{ }^{+} \text {cells. } \\
\text { Induces and maintains brown/beige adipogenesis }\end{array}$ & {$[104,145,164]$} \\
\hline Taurine & Induces PE lineage, promotes insulin expression in $\beta$-like cells & [185] \\
\hline Thiazovivin & Rho-kinase inhibitor, induces DE lineage & [157] \\
\hline ТPB & $\begin{array}{c}\text { A PKC activator, enhances generation of NKX } 6.1^{+} \text {PPs and } \\
\text { endocrine progenitors }\end{array}$ & [78] \\
\hline TTNPB & Analog of retinoic acid, aids in pancreas specification & [54] \\
\hline Vitamin C & $\begin{array}{l}\text { Induces PDX } 1^{+} \mathrm{NKX} 6.1^{+} \text {PPs and prevents the formation of } \\
\text { polyhormonal cells during } \beta \text {-cells differentiation. Also induces } \\
\text { expression of hepatocyte-specific genes and aid in its maturation process. } \\
\text { Induces mesoderm lineage in adipocyte differentiation }\end{array}$ & {$[78,186,187]$} \\
\hline Wortmannin & Inhibits GSK3- $\beta$ and PI3K activity and induces DE lineage & [149] \\
\hline XAV939 & $\begin{array}{c}\text { Tankyrase inhibitor which targets Wnt } / \beta \text { signaling and promotes } \beta \text {-like } \\
\text { cell maturation }\end{array}$ & [53] \\
\hline Y27632 & Inhibitor of ROCK, enhances PPs and supports cluster formation & [124] \\
\hline
\end{tabular}

ALK5Iii, Activin receptor-like kinase 5 inhibitor II; bFGF, Basic fibroblast growth factor; Db-cAMP, Ascorbic acid Dibutyryl-cyclic AMP; DMSO, Dimethyl sulfoxide; EGF, Epidermal growth factor; GDF8, Growth Differentiation Factor 8; HGF, Hepatocyte growth factor; IBMX, Isobutyl methylxanthine; IDE1/2, Definitive Endoderm 1/2 inducer; IGF-1, Insulin-like growth factor 1; ITS-X, Insulin-Transferrin-Selenium-Ethanolamine; KGF, Keratinocyte growth factor, NECA, N-Ethylcarboxamidoadenosine; PdBU, Phorbol dibutyrate; SANT-1, Sonic hedgehog agonist-1, TPB, Trifluoromethyl phenyl pentadienoylamino benzolactam; TTNPB, Tetrahydro tetramethyl naphthalenyl propenyl benzoic acid; DE, Definitive Endoderm; PPs, Pancreatic Progenitors; PE, Pancreatic Endoderm. 
Mature Hepatocyte Differentiation

Oncostatin M (OSM) is important for hepatic maturation [174]. Oncostatin M which belongs to interleukin (IL)-6 group of cytokines is produced by hematopoietic cells. In addition, various chemical compounds and small molecules such as dimethylsulfoxide (DMSO), dexamethasone, hydrocortisone-21- hemisuccinate and Ile-(6) aminohexanoic amide (dihexa) are used for iPSC differentiation from definitive endoderm to mature hepatocytes [72,140,141,143]. These molecules regulate specific target(s) in signaling and epigenetic mechanisms, as well as manipulate cell fate without genetic alterations. Expression of HNF1 $\alpha$ and HNF4 $\alpha, \mathrm{LXR}, \mathrm{A} 1 \mathrm{AT}, \mathrm{ABCA} 1, \mathrm{CEBP} \alpha$, albumin, liver-specific microRNAs miR122, miR148a, and miR194 peaks in mature hepatocytes (Figure 3) [72]. Some markers such as tryptophan-2,3-dioxygenase (TDO) [141], tyrosine amino-transferase (TAT), CEBP- $\beta$, specific cytochrome P450 superfamily, liver-specific arginase-1 (involved in the production of urea), and asialoglycoprotein receptor 1, as well as liver-specific enzymes, such as uridine diphosphate glucuronosyl transferase 1 A1 (UGTA1) and fumarylacetoacetate hydrolase (FAH), are assessed to identify mature hepatocytes [72,140,141,143].

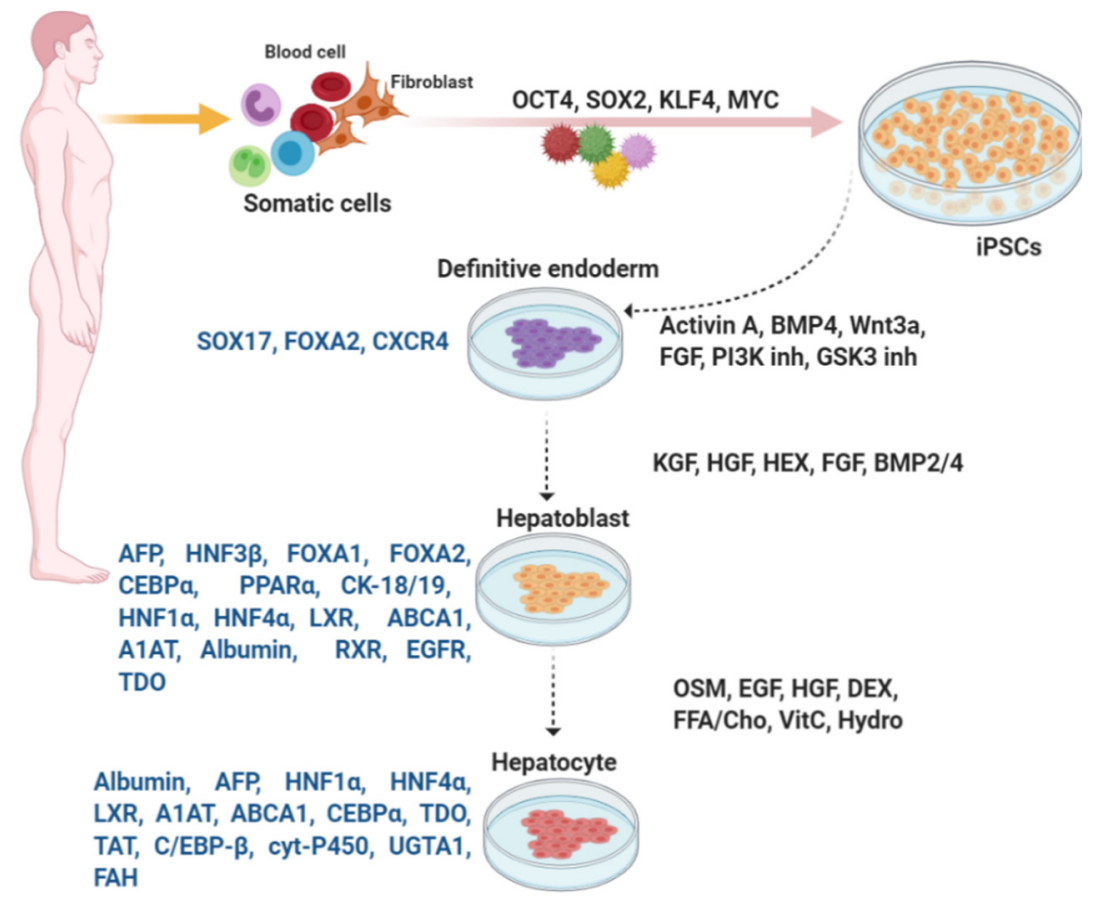

Figure 3. In vitro differentiation of hepatocytes from iPSCs. Similar to differentiation of $\beta$-like cells, embryonic development is mimicked by addition of numerous large or small molecules to induce each stage of differentiation. Expression of the key transcription factors is monitored for evaluation of the consecutive stages of differentiation.

\subsubsection{Functional Evaluation of iPSC-Derived Hepatocytes}

iPSC-derived hepatocytes secrete albumin [8,10,72], store lipids [10], accumulate glycogen $[8,10]$, produce urea [8,10], and eliminate ammonia [8]. They also express liver transcription factors and asialoglycoprotein receptor (specific for differentiated hepatocytes), absorb low-density lipoprotein (LDL) [188], express cytochrome p450s (3A4 and 7A1) [8,10], as well as E-Cadherin [10]. As with $\beta$-like cells, most iPSC-derived hepatocytes resemble more fetal or neonatal cells [189], as they have lower expression of enzymes involved in metabolic functions and drug metabolism [190]. The cytochrome P450s of the liver play critical roles in the maintenance of lipid homeostasis and detoxification of endogenous compounds and drugs. Recently, use of ECM components, such as collagen, laminin, and fibronectin, may mimic the liver microenvironment and allow cells to arrange themselves in a 
more physiologically relevant manner [191,192]. A 3D culture system can also be used to increase the efficiency of differentiation.

Moreover, genes involved in cell-cycle and cell-proliferation pathways have significantly higher expression in fetal than adult liver. In contrast, genes highly expressed in adult liver are metabolism-related genes, including three major functional categories: metabolism of fatty acids, xenobiotics, and glucose [193]. To mimic these metabolic changes, low glucose concentration media during the last four days of differentiation with added free fatty acids, bile acids, cholesterol, corticoids, epidermal growth factor (EGF), and rifampicin, promote further hepatocyte maturation of human iPSCs [72]. Maturation in the organ-like microenvironment is associated with increased expression of genes encoding insulin signaling/lipogenesis and mature, clinically relevant enzymes [72]; there is no quantitative difference in intracellular triglyceride content, mitochondrial number, and expressed levels of mitochondrial DNA [72]. However, cytochrome P450 activity (CYP3A4) in iPSC-derived hepatocytes after exposure to rifampicin is at the level of human fetal hepatocytes but inferior to that in adult human hepatocytes [72].

iPSC-derived hepatocytes have been used to resolve inherited metabolic disorders of the liver, such as A1AT deficiency, familial hypercholesterolemia, and glycogen storage disease type 1a [194]. Gene editing of an $\alpha 1$-antitrypsin-deficient iPSC line restores the structure and function of $\alpha 1$-antitrypsin in the derived hepatocytes both in vitro and in vivo [195].

Table 3. Overview of protocols used for differentiation of hepatocytes from various sources of iPSCs.

\begin{tabular}{|c|c|c|c|c|}
\hline iPSC Source & Protocol & In Vivo/Vitro Efficacy & Stage/Day & Ref. \\
\hline Human iPSCs & $\begin{array}{c}\text { Days 1-3: Wnt3A, Activin A. Days 4-5: Activin } \\
\text { A. Days 5-8: KSR, DMSO. Days 9-14: HGF, } \\
\text { OSM, Hyd }\end{array}$ & $\begin{array}{l}\text { Glycoproteins, glycogen, } \\
\text { and lipid production. } \\
\text { secretion of albumin, urea, } \\
\text { AFP, and A1AT; cytochrome } \\
\text { P450 1A2 and 3A4 activities }\end{array}$ & $3 / 14$ & [10] \\
\hline Human iPSCs & $\begin{array}{c}\text { Day 1: Wnt3A, Activin A, BMP4, bFGF. Days } \\
\text { 2-3: Activin A, BMP4, bFGF. Days 4-5; KGF, } \\
\text { ALK inh. Days 6-9; KGF, BMP2, BMP4, bFGF. } \\
\text { Days 10-16/18: Forskolin, ALK inh, EGF, LPA, } \\
\text { Dex, S1P, GSK3ß inh. Days 17/19-36/38: ALK } \\
\text { inh, Forskolin }\end{array}$ & $\begin{array}{l}\text { Glycogen production; } \\
\text { secretion of albumin, urea, } \\
\text { AFP; cytochrome P450 3A4 } \\
\text { activities; ammonia } \\
\text { elimination }\end{array}$ & $6 / 36-38$ & [8] \\
\hline Human iPSCs & $\begin{array}{l}\text { Days 1-2: BMP4, Activin A, FGF2. Days 3-4: } \\
\text { Activin A. Days 5-9: BMP4, FGF2. Days 10-13: } \\
\text { Activin A, FGF10, RA. Days 14-18: EGF, Dex, } \\
\text { FFA, Hyd, Nicotinamide, IL-6, TGF } 31 \text {, VitC, } \\
\text { ITS-X, sDLL-1 }\end{array}$ & $\begin{array}{l}\text { Glycogen, albumin, urea, } \\
\text { and A1AT production; } \\
\text { cytochrome P450 3A4 } \\
\text { activities, intracellular } \\
\text { triglyceride content }\end{array}$ & $4 / 18$ & [72] \\
\hline Human iPSCs & $\begin{array}{c}\text { Days 0-3: Activin A. Days 4-7: BMP2, FGF4. } \\
\text { Days 8-13: HGF, KGF. Days 14-18: OSM, Dex. } \\
\text { Days 19-21: OSM, Dex, N2B27 }\end{array}$ & $\begin{array}{l}\text { Glycogen, albumin, } \\
\text { and urea, production; } \\
\text { cytochrome P450 activity }\end{array}$ & $5 / 21$ & [196] \\
\hline Human iPSCs & $\begin{array}{l}\text { Days 1-3: B27- }{ }^{-} \text {, Sodium butyrate, Wnt3a, } \\
\text { Activin. Days 4-5/6: B27, Wnt3a, Activin. Days } \\
\text { 6/7-9/10: KSR, DMSO, Glutamine, 2ME. Days } \\
\text { 9/10-11/12: iPSCs were mixed with MSCs and } \\
\text { HUVECs and cultured within OSM, } \\
\text { Transferrin, Hyd, VitC, Insulin, GA-1000, } \\
\text { Bovine brain extract, hEGF, FBS, HGF, Dex }\end{array}$ & $\begin{array}{l}\text { Cellular polarity and bile } \\
\text { acid transport; urea } \\
\text { production and glycogen } \\
\text { accumulation }\end{array}$ & $3 / 12$ & [140] \\
\hline Mouse iPSCs & $\begin{array}{c}\text { Days 1-5: Activin A, Wnt3a. Days 6-10: BMP4, } \\
\text { FGF-2. Days 11-15: HGF. Days 16-20: HGF, } \\
\text { OSM, Dex, ITS-X }\end{array}$ & $\begin{array}{l}\text { Urea and albumin } \\
\text { production }\end{array}$ & $4 / 20$ & {$[141]$} \\
\hline Human iPSCs & $\begin{array}{l}\text { Days 1-3: B27, Activin A, Wnt3a. Days 4-10: } \\
\text { DMSO, KSR. Days 11-20: HGF, OSM, Hyd }\end{array}$ & $\begin{array}{l}\text { Urea and albumin } \\
\text { production }\end{array}$ & $3 / 20$ & {$[143]$} \\
\hline
\end{tabular}

KSR, knockout serum replacement; Hyd, Hydrocortisone; LPA, lysophosphatidic acid; S1P, sphingosine-1-phosphate; ITS-X, Insulin-transferrin-selenium-ethanolamine; OSM, Oncostatin M; HGF, Hepatocyte growth factor; FGF, Fibroblast growth factor; BMP4, Bone morphogenetic protein 4; Dex, dexamethasone; KGF, keratinocyte growth factor; ALK inh, activin receptor-like kinase inhibitor; RA, retinoic acid; 2-ME, 2-Mercaptoethanol; EGF, Epidermal growth factor; IL-6, Interlukin-6; AFP, Alpha-fetoprotein; A1AT, Alpha-1-antitrypsin. 


\section{3. iPSC-Derived Skeletal Muscle Cells}

\subsubsection{Development of Skeletal Muscle}

Nearly all skeletal muscle cells are derived from paraxial mesoderm, forming somites, then dermamyotome and finally the myotome [197]. For myotome development, muscle progenitor cells delaminate from the four edges of the dermomyotome; these progenitor cells also migrate into the limb buds. Paired box protein3 (PAX3) as well as cMET, a tyrosine kinase receptor that binds HGF, are important for this delamination and migration [198]. Pax3 is then downregulated and the delaminating progenitor cells differentiate into myoblasts [198]. The expression of myogenic factor 5 (MyF5), myogenic regulatory factor $(M r F 4)$, and myogenic differentiation $(M y o D)$ is increased in the myoblasts, which differentiate into myocytes through the action of myogenin (MyoG), MrF4, and $M y o D$ [197]. The myocytes fuse and mature into multinucleated muscle fibers forming a continuous muscle layer, the myotome. Signaling molecules such as $\mathrm{SHH}$, Wnt proteins, and BMPs are involved in the developmental processes [5,197].

During the early embryonic/primary phase, primary myofibers are generated, which derive from $\mathrm{PAX}^{+}$or $\mathrm{PAX}^{+} / \mathrm{PAX}^{+}$dermomyotomal progenitors [5]. These myofibers, which form the early myotomes and limb muscles, express a specific set of proteins, such as myosin light chain 1 (MYL1) and slow myosin heavy chain (MYH). In the fetal/secondary phase, expression of Pax7 and downregulation of Pax3 are initiated in a subset of $\mathrm{PAX}^{+}$myogenic progenitors. These $\mathrm{PAX} 7^{+}$myogenic precursors form primary fibers and then generate the secondary or fetal fibers expressing specific markers, such as $\beta$-enolase or MYL3 [5,199]. At this time, the fibers express fast MYH isoforms and muscle growth is continued by cell fusion and the inclusion of myonuclei from proliferating $\mathrm{PAX} 7^{+}$progenitors. A portion of the $\mathrm{PAX}^{+}$progenitors will also generate satellite cells, the pool of adult muscle stem cells [199].

\subsubsection{Differentiation of iPSCs into Myocytes}

There are two protocols for derivation of skeletal muscle cells from iPSCs: i) forced overexpression of muscle-specific transcription factors, such as PAX3, PAX7, and MYOD, and ii) a step-wise induction of skeletal muscle by small molecules to inhibit or activate relevant signaling pathways in myogenesis (Table 4).

\section{Overexpression of Muscle-Specific Transcription Factors}

Activation of MYOD in a variety of differentiated cell lines is sufficient to activate a downstream program for terminal muscle differentiation [200]. Different systems of gene expression, such as lentiviral and piggyBac-based approaches, are used to express PAX7 and MYOD1 in iPSCs [161,201]. $M Y O D 1$ overexpression, particularly in undifferentiated cells, drives them along the myogenic lineage with 70-90\% efficiency, and myocytes reach maturity within two weeks of differentiation [161]. Overexpression of PAX7 in two well-characterized human iPSC lines, generated from normal donor's fibroblasts, converts these cells into myotubes [201]. Overexpressing muscle-specific transcription factors secures high efficiency of progenitor preparation and yields progenitors more rapidly [161,201]. Progenitors can also be sufficiently enriched by fluorescence-activated cell sorting (FACS) [201,202]. However, a high level or sustained expression of $M y o D$ induces cell cycle arrest [203]. As these methods use exogenous genes, the resulting cells may not fully reflect the normal processes of progenitor proliferation/differentiation/maturation. Furthermore, genetic modification is another concern when progenitors are destined for cell-based therapy in patients. Myogenic progenitors exposed to growth factors and/or signaling molecules may be more suitable for transplantation in patients.

Step-Wise Induction of Skeletal Muscle Cells by Small Molecules

Some small molecules secreted as paracrine factors play important roles in muscle development, controlling proliferation, migration, and differentiation from mesodermal cells 
into somites and dermomyotome [204]. iPSCs are treated with a combination of GSK-3 $\beta$ inhibitor (6-bromoindirubin-3'-oxime (6-BIO) or CHIR99021), adenylyl cyclase activator, and bFGF, which promote myogenic differentiation [148,160]. Administration of CHIR99021 is a critical step, as lower concentrations fail to result in myogenic progenitors and high concentrations or a longer exposure is toxic $[169,202,205]$. By contrast, 6-BIO demonstrates the lowest toxicity among other GSK-3 $\beta$ inhibitors [206]. Inhibition of GSK-3 $\beta$ promotes Wnt signaling, which in turn promotes cellular differentiation to a mesoderm or endoderm fate [202,205], resulting in up to $90 \%$ of myogenic cells, evidenced by exclusive $\mathrm{PAX}^{+} / \mathrm{MYOG}^{+}$populations in vitro [148].

FGF2, EGF, IGF-1, HGF, and platelet-derived growth factor (PDGF) have also been used to enhance myogenic differentiation [169,202,205-208]. DMSO and PI3K inhibitors (LY294002) are also used to increase differentiation efficiency toward the mesodermal lineage in the presence of BMP4 [148]. DMSO enhances the differentiation efficiency of PSCs into terminal cell lineages through activation of the retinoblastoma protein [209]. Likewise, PI3K inhibition increases the differentiation of stem cells into mesodermal lineages through the promotion of activin A and nodal signaling [144]. During embryonic development, morphogen gradients of BMPs, Wnt, FGF, and retinoic acid control somitogenesis and eventual separation of paraxial, intermediate, and lateral plate mesoderm [204]. BMP4, in tandem with FGF and Wnt signaling, potentiates development of the paraxial mesoderm along the primitive streak into the dermomyotome, which forms the skeletal musculature of the body [204,210].

After 7, 12, and 36 days, cells are differentiated into embryoid bodies (EBs), myoblasts, and myotubes, respectively [160]. From day 17 onwards, cells proliferate rapidly, cultures reaching complete confluency after 24 days; multinucleated myotube-like cells are observed between 30 and 40 days [169]. At day 36, up to $64 \%$ of nuclei express the late-stage skeletal muscle transcription factor MYOG, indicating highly efficient differentiation toward a skeletal muscle fate [148]. Differentiated iPSCs also have higher expression of MYOD1, as well as of $M Y H$ and the cholinergic receptor CHRNA1 [148]. Under proliferating conditions, expanded myogenic progenitors (about 25 days) of iPSCs express PAX7 in a subset of cells. Myogenic progenitor cultures contain stable $\mathrm{PAX}^{+}$cells during the main part of the expansion period [169] (Figure 4).

For inducing spontaneous twitching in cell culture, serum-free medium is used in terminal differentiation, resulting in robust spontaneous myotube contractions [148,205]. Supplementation of $0.5-2 \%$ FBS increases the overall survival of the culture but also the proliferation rate of mononucleated cells, resulting in overgrowth of the cell culture [169], while supplementation with serum free-medium results in fibers with fast $\mathrm{MYH}$, titin, and $\alpha$-actinin, as well as striation patterns contracting spontaneously.

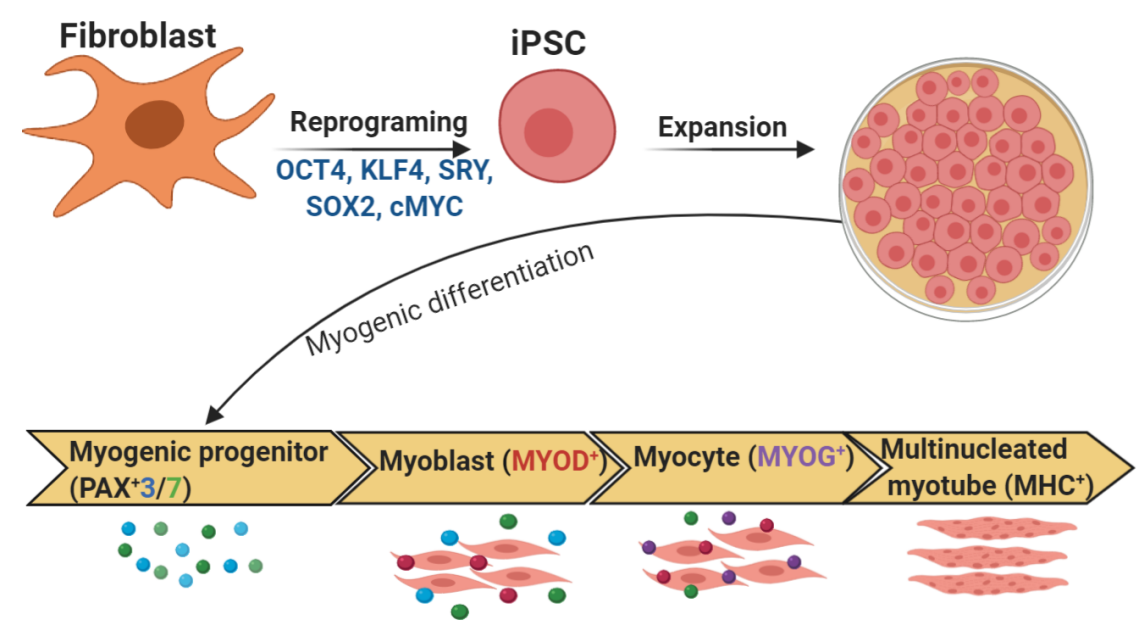

Figure 4. In vitro differentiation of myotubes from iPSCs. Addition of a number of large or small molecules induces each stage of differentiation, which is monitored by expression of key transcription factors during the consecutive stages of differentiation. 


\subsection{3. iPSC-Derived Skeletal Muscle Cells and Insulin Resistance}

Molecular defects contributing to metabolic dysregulation have been identified in iPSCs-generated from patients with Donohue syndrome $[160,211]$. Morphologically, these iPSCs are differentiated normally, but both mRNA and protein expression of the insulin receptor are reduced in iPSCs generated from these patients $[160,211]$. However, the results of insulin-stimulated phosphorylation of downstream signaling are not consistent. Both reduced [160] and no changes [211] in insulin-stimulated phosphorylation of insulin receptor, insulin receptor substrate 1 (IRS1), and Akt have been reported. Moreover, these studies have demonstrated both elevated [211] and reduced [160] insulin-stimulated phosphorylation of IGF1 receptor; extracellular signal-regulated kinase (ERK) phosphorylation tends to be reduced [211], while there is no difference in its protein level [160]. Basal expression of metabolic and growth-regulatory genes, including ras-related associated with diabetes (RAD1), hexokinase 2, and GLUT4 is reduced in iPSCs generated from patients with Donohue syndrome [160].

As insulin is involved in regulating the unique properties of self-renewal and pluripotency, insulin-resistant iPSCs are frequently defective in their ability of self-renewal [212]. Indeed, this circumstance is a major bottleneck in the use of reprogrammed somatic cells for subsequent differentiation to mature cells, regardless of whether they are intended for research or therapy. Indeed, the pathogenetic processes to be examined is also a key factor determining stem cell differentiation. Expression of the early growth response genes is increased in iPSC-derived healthy myotubes in response to insulin, while insulin responsiveness is decreased in insulin-resistant iPSCs [160]. These iPSCs also show higher OCR, higher extracellular acidification, increases in oxidative phosphorylation protein complexes III and V, as well as increased lactate release [211]. Metabolic effects of insulin are mimicked in healthy iPSC-derived myotubes with increased 2-deoxyglucose uptake, glycogen synthase activity, and glycogen accumulation [160]. This is similar in magnitude to the best insulin-responsive murine skeletal muscle cell models. In contrast, insulin-resistant iPSC-derived myotubes demonstrate an almost complete failure of insulin-stimulated, but not basal, glucose uptake, glycogen synthase activity, and glycogen accumulation [160].

Insulin-resistant iPSCs exhibit mitochondrial dysfunction with an increase in mitochondrial number and decrease in size [213]. This dysfunction is associated with elevated expression of mitochondrial fission factor and inverted formin 2, which both enhance mitochondrial fission, while expression of genes regulating mitochondrial fusion are unchanged [213]. Increased mitochondrial fission has also been reported in pancreatic $\beta$-cells and skeletal muscle of T2D patients [214]. Moreover, alterations in mitochondrial DNA could be associated with genetic risk factors for T2D [215]. Insulin-resistant iPSCs exhibit distinct phenotypes with elevated lactate levels and decreased citrate synthase activity [213]. Interestingly, increased plasma lactate levels $[216,217]$ and decreased citrate synthase activity have been reported in skeletal muscle [218] and adipose tissue [219] in insulin resistance and T2D. In the iPSCs, differences in citrate synthase activity are reversed after exogenous oxaloacetate administration [213], indicating that availability of substrate might be limiting for tricarboxylic acid (TCA) cycle metabolism in insulin resistance.

Accumulation of glycogen in the myotubes from Pompe patients is reversed in gene-edited iPSC-derived myotubes; GAA mRNA expression as well as its enzymatic activity are raised 5.5-fold and 3-fold over levels in healthy control myotubes [169]. This shows the possibility of combining a myogenic differentiation protocol with gene editing in iPSCs to produce gene-corrected skeletal muscle cells. 
Table 4. Overview of protocols used for differentiation of myotubes from various sources of iPSCs.

\begin{tabular}{|c|c|c|c|c|}
\hline iPSCs Source & Protocol & In Vivo/Vitro Efficacy & Stage/Day & Ref. \\
\hline Human iPSCs & $\begin{array}{l}\text { Days 1-7: GSK3 inh, bFGF, Forskolin. Days 8-9: } \\
\text { Serum free media. Days 10-36: Horse serum }\end{array}$ & $\begin{array}{l}\text { Insulin-stimulated glucose } \\
\text { uptake, glycogen synthase } \\
\text { activity, glycogen } \\
\text { accumulation }\end{array}$ & $3 / 36$ & [160] \\
\hline Human iPSCs & $\begin{array}{c}\text { Days 1-5: GSK3 inh. Days 5-19: bFGF, DMSO. } \\
\text { Days 20-35: KSR, ITS-X }\end{array}$ & Glycogen accumulation & $3 / 35$ & [169] \\
\hline Human iPSCs & $\begin{array}{l}\text { Days -1-0: DMSO. Days 0-1.5: Insulin, } \\
\text { transferrin, FGF2, PI3K inh, BMP4, GSK3 inh. } \\
\text { Days 1.5-7: Insulin, Transferrin, FGF2, PI3K inh. } \\
\text { Days 8-12: } 15 \% \text { FBS. Days 13-36: horse serum }\end{array}$ & Spontaneous contractions & $3 / 36$ & [148] \\
\hline Human iPSCs & $\begin{array}{l}\text { Days 1: MyoD overexpression. Day 3: Adding } \\
\text { G418. Day 4: ROCK inh. Day 5: ROCK inh, Dox. } \\
\text { Days 6-10: } \alpha \text { MEM, KSR, 2-ME. Days 11-13: } \\
\text { horse serum, IGF1, 2-ME, Glutamin }\end{array}$ & $\begin{array}{l}\text { Fusion potential both } \\
\text { in vitro and in vivo }\end{array}$ & $3 / 13$ & [161] \\
\hline Equine iPSCs & $\begin{array}{c}\text { Day 1: mTeSR1 media. Days 2-3: ITS-X, GSK3 } \\
\text { inh, ALK inh. Days 4-5: ITS-X, bFGF, GSK3 inh, } \\
\text { ALK inh. Days 6-7: IGF1, bFGF, HGF, BMP inh. } \\
\text { Days 8-12: IGF1, KSR. Days 12-30: IGF1, } \\
\text { KSR, bFGF }\end{array}$ & $\begin{array}{l}\text { Intracellular } \mathrm{Ca}^{2+} \text { release in } \\
\text { response to } \mathrm{KCl} \text {-induced } \\
\text { membrane depolarization }\end{array}$ & $5 / 30$ & [220] \\
\hline Equine iPSCs & $\begin{array}{l}\text { Days 1-14: media containing high glucose, } 10 \% \\
\text { FBS. Day 15: MyoD overexpression. Day 16: } \\
\text { washing with PBS and adding puromycin for } \\
\text { selection of positive transductants. } \\
\text { Puromycin-resistant cells were cultured in high } \\
\text { glucose media containing } 10 \% \text { FBS then Dox was } \\
\text { added and cells were differentiated for } 7 \text { days. }\end{array}$ & $\begin{array}{l}\text { Intracellular } \mathrm{Ca}^{2+} \text { release in } \\
\text { response to } \mathrm{KCl} \text {-induced } \\
\text { membrane depolarization }\end{array}$ & ?/? & [220] \\
\hline
\end{tabular}

KSR, knockout serum replacement; ITS-X, Insulin-transferrin-selenium-ethanolamine; HGF, Hepatocyte growth factor; FGF, Fibroblast growth factor; BMP, Bone morphogenetic protein; ALK inh, activin receptor-like kinase inhibitor; 2-ME, 2-Mercaptoethanol; IGF-1, Insulin-like growth factor 1; Dox, Doxycycline.

\subsection{The iPSC-Derived Adipocyte}

\subsubsection{Development of Adipocytes}

The overall function of white adipose tissue (WAT) is to store energy, whereas brown adipose tissue (BAT) dissipates energy in a heat-producing process called thermogenesis. Postnatally, a third form of adipose tissue has been identified ('beige') but its function and origin is enigmatic; it has been reported that beige adipocytes are generated from unique precursor cells [221], but there is also evidence that they may be generated from WAT by transdifferentiation [222]. Adipogenesis is the differentiation of fibroblast-like MSCs into adipocytes. This is generally divided into generation of adipocyte progenitors (or pre-adipocytes) from multipotent MSCs and a differentiation step. Adipogenesis is controlled by several groups of transcription factors, including the CEBP gene family, PPAR $\gamma$, PPAR $\gamma$ coactivator- $1 \alpha$ (PGC-1 $\alpha$ ), and PRD1-BF-1-RIZ1 homologous domain containing protein-16 (PRDM16) [223]. PPAR $\gamma$, a master regulator of adipogenesis, is crucial for maturation of adipocytes [224]. In addition, PPAR $\gamma$ is a receptor for insulin-sensitizing drugs [225]. Expression of Cebpa is important for terminal differentiation of adipocytes, as its absence leads to insulin resistance; development of BAT is independent of Cebpa [226]. The expression of PGC-1 $\alpha$ is high in BAT, where it upregulates expression of several genes of the TCA cycle and contributes to fatty acid utilization [227]. PRDM16 regulates the differentiation of brown and beige adipocytes as its overexpression in WAT promotes beige adipocyte development [228]; its deletion causes a profound loss of beige adipocyte function in mice [229]. 


\subsubsection{Differentiation of iPSCs into Adipocytes}

Two protocols for differentiation of adipocytes from iPSCs have been reported: (i) forced overexpression of white/brown adipocyte-specific transcription factors, such as PPAR $\gamma$, PRDM16, and CEBP $\alpha$, and (ii) step-wise induction of adipocytes by small molecules to inhibit or activate relevant signaling pathways in adipogenesis (Table 5).

\section{Formation of Embryoid Bodies}

Embryoid bodies are three-dimensional cell aggregates formed in suspension by PSCs, which differentiate into cells of all three germ layers. Formation of EBs is a routine inductive step to generate specific cell lineages from PSCs. For formation of EBs, iPSCs are cultured in a floating condition with medium containing undefined components, such as fetal bovine serum (FBS), knock-out serum replacement (KSR) or albumin products for 2-7 days $[176,230]$. Short-term retinoic acid treatment in this stage enhances the number of iPSC-derived EBs in a dose-dependent manner via induction of both cell proliferation and survival [231]. Differentiated EBs express all genes associated with each of the three germ layers, such as AFP or FOX2 (for endoderm), SOX1 or $\beta 3$-tubulin (for ectoderm), and Brachyury or $\alpha$-smooth muscle actin (AKTA2) (for mesoderm) [232,233].

\section{Adipogenic Differentiation}

The second step of differentiation, consists of culturing iPSC-derived EBs under adherent conditions with an adipogenic cocktail, including FBS, dexamethasone, isobutylmethylxanthin (IBMX), pioglitazone, and insulin $[176,186,230,231,234]$. In most studies, differentiated EBs are transfected with vectors containing brown or white adipocyte-specific transcription factors and then treated with an adipogenic cocktail. Insulin is a potent adipogenic hormone that stimulates transcription factors responsible for differentiation of pre-adipocytes into mature adipocytes [164]. Moreover, insulin stimulates cells to take up glucose [224]. Insulin promotes not only expression of adipogenic genes (PPARG and FABP4), but also expression of brown fat genes (uncoupling protein 1 (UCP1) and PGC1A) [164]. IBMX also increases the expression of thermogenic and adipogenic genes (PPARG, FABP4, UCP1, and PGC1A) [164,235]. Dexamethasone directly increases the levels of intracellular cyclic adenosine monophosphate (cAMP) and lipolysis in adipocytes [236] and upregulates the expression of $P G C 1 A, P P A R G, F A B P 4$, and UCP1 [164]. Using pioglitazone, especially in combination with insulin, results in $>95 \%$ cell differentiation into lipid-accumulating adipocytes in comparison with $60-80 \%$ cell differentiation by treatment with either agent alone [175].

\section{Differentiation of White Adipocytes from iPSCs}

Human iPSC-derived white adipocyte-like cells exhibit lipid accumulation and transcription of adipogenesis-related genes, such as CEBPA, PPARG2, LEP, FABP4, and fatty acid-binding protein 4 (aP2) $[230,231,233,234]$. These iPSC-derived adipocytes preserve adipocyte characteristics for 4 weeks after transplantation into mice [234]. Overexpression of PPARG2, in combination with adipogenic differentiation medium, is used to enhance differentiation efficiency [176]. Transfected iPSCs show the morphologic appearance of mature white adipocytes even after turning off PPARG2 transgene expression, and exhibit insulin-stimulated glucose uptake and inducible lipolysis [176]. Without overexpressing adipocyte-specific transcription factors, a method based on retinoic acid treatment for generation of iPSC-derived adipocyte was recently developed [231]; although the functionality of these iPSC-derived adipocyte was not evaluated, the differentiated adipocytes demonstrate higher expression of transcription factors, including FABP4, BODIPY and adiponectin [231]. Patient-specific iPSC-derived adipocytes serve as a platform to investigate diseases related to adipose tissue, e.g., congenital generalized lipodystrophy (CGL), which is characterized by near absence of adipose tissue, severe insulin resistance, hypertriglyceridemia, hepatic steatosis and early-onset 
diabetes [237]. Lipid-containing cells are barely detectable in iPSC-derived adipocytes from patients with CGL and these cells have lower expression of PPAR $\gamma 2$ [233].

Differentiation of Brown Adipocytes from iPSCs

Overexpression of PPARG2, CEBPB, and PRDM16 in human [176,238] or mouse [238] iPSCs induces brown adipocytes with the ability of expressing brown adipose tissue markers and releasing glycerol in response to forskolin and $\beta$-adrenergic agonists. Differentiated brown adipocytes have multilocular lipid droplets and abundant mitochondria $[176,238]$, high oxygen consumption rate $[176,238]$ and extracellular acidification rate [176], with elevated ATP turnover and proton leak [176], important functional characteristics of brown adipose tissue. Furthermore, transplantation of programmed white and brown adipocytes to immune-compromised mice show a morphology characteristic of primary adipocytes [176]. Transplantation of iPSC-derived brown adipocytes generated from normal or diabetic KK-Ay mice into high fat diet-fed mice results in a lower body weight gain and reduced serum glucose elevation, lower urine glucose, serum levels of total cholesterol, LDL, triglycerides, phospholipid, and non-esterified fatty acids [238]. These results demonstrate that iPSC-derived brown adipocytes are metabolically active after transplantation and suppress diet-induced obesity, dyslipidemia, and T2D.

\section{Differentiation of Beige Adipocytes from iPSCs}

Adding the Wnt agonist (CHIR99021), recombinant BMP4, VEGFA proteins, and TGF- $\beta$ inhibitor (SB431542) with an adipogenic cocktail efficiently differentiates FOXF1 ${ }^{+}$splanchnic mesoderm toward beige adipocyte-like cells [239]. Differentiated cells accumulate lipids and express beige adipocyte-enriched genes [239]. Cold exposure leads to secretion of IL-4 from type 2 innate lymphoid cells, which directly stimulates PDGFR $\alpha^{+}$adipogenic precursors within subcutaneous adipose tissue and increases their differentiation into beige adipocytes [240]. Pretreatment of iPSC-derived MSCs with IL- 4 and TGF- $\beta$ inhibitor leads to a synergistic increase in UCP1 transcription, as well as beige adipogenic precursor markers (PDGFRA and EBF2) [239]. Treatment of human iPSCs with two mesodermal inducers (BMP4 and activin A), following an adipogenic cocktail, induces differentiation of beige adipocytes, which store triglycerides and express $U C P 1, P G C 1 A$, and PRDM16; this characterizes beige and brown adipocytes but not progenitor or mature brown adipocyte markers (MYF5 or ZIC1), suggesting that iPSC-derived cells are not of the brown adipocyte lineage [186]. Activation of a thermogenic program under long-term $\beta$-adrenergic stimulation is a key functional feature of beige adipocytes [241]. Accordingly, treatment of iPSC-derived beige adipocytes with a cAMP analog upregulates thermogenic genes, increases intracellular mitochondrial content, and induces shrinking of lipid droplets [186]. Moreover, iPSC-derived beige adipocytes demonstrate a 2.5-fold increase in OCR in response to acute cAMP stimulation [186]. Treating subcutaneous primary adipocytes with iPSC-beige adipocytes derived from T2D patients increases phosphorylation of AKT and glucose uptake in the primary adipocytes upon insulin challenge [239].

Table 5. Overview of protocols used for differentiation of adipocytes from various sources of iPSCs.

\begin{tabular}{|c|c|c|c|c|c|}
\hline iPSC Source & Protocol & Adipocyte & In Vivo/Vitro Efficacy & Stage/Day & Ref. \\
\hline Human iPSCs & $\begin{array}{c}\text { Days 0-2: Y-27632 and 15\%FBS. Days 2-4: } \\
10 \mu \mathrm{M} \text { RA. Days 4-6: 0.1 } \mu \text { M RA. Days 6-7: } \\
\text { RA-. Days 7-12: EB plating onto } \\
\text { gelatin/matrigel-coated plates. Days 12-20: } \\
\text { bFGF. Days 20-30/34: knockout DMEM-F12 } \\
\text { containing 10\% KSR, Glutamax, IBMX, Dex, } \\
\text { Insulin, Indomethacin, and Pioglitazone }\end{array}$ & White & NR & $3 / 30-34$ & [231] \\
\hline
\end{tabular}


Table 5. Cont.

\begin{tabular}{|c|c|c|c|c|c|}
\hline iPSC Source & Protocol & Adipocyte & In Vivo/Vitro Efficacy & Stage/Day & Ref. \\
\hline Human iPSCs & $\begin{array}{l}\text { Days 0-2: 20\% KSR. Day 2-5: RA. Day 6-12: } \\
\text { 20\% KSR. Day 12-22: 10\% KSR, IBMX, Dex, } \\
\text { Insulin, Indomethacin, Pioglitazone on } \\
\text { Poly-L-ornithine and fibronectin plate }\end{array}$ & White & NR & $2 / 22$ & [230] \\
\hline $\begin{array}{l}\text { Human and } \\
\text { mouse iPSCs }\end{array}$ & $\begin{array}{l}\text { Days 0-3: 10\% FBS. Days 3-5: 10\% FBS, RA } \\
(25 \mu \mathrm{M}) \text {. Days 5-7: 10\% FBS, RA ( } 50 \mu \mathrm{M}) \\
\text { (floating condition). Days 7-17: 10\% FBS, } \\
\text { RA (50 } \mu \mathrm{M}) \text { (adherent conditions) and } \\
\text { overexpression of PRDM16. Days 17-19: } \\
\text { 10\% FBS, IBMX, Dex, Indomethacin, } \\
\text { Insulin, T3, Rosiglitazone. Days 19-27: } 10 \% \\
\text { FBS, Insulin, T3, Rosiglitazone }\end{array}$ & Brown & $\begin{array}{c}\downarrow \text { Body weight, serum } \\
\text { glucose, LDL, total } \\
\text { cholesterol, } \\
\text { and triglycerides, } \\
\text { and urine glucose in } \\
\text { high fat diet-fed mice }\end{array}$ & $2 / 27$ & [238] \\
\hline Human iPSCs & $\begin{array}{c}\text { Days 0-7: } 15 \% \text { FBS. Days 7-12: } 10 \% \text { FBS, } \\
\text { 1\% GlutaMAX. Days 12-33: KSR, Dex, } \\
\text { hPlasmanate, Insulin, Rosiglitazone }\end{array}$ & White & $\begin{array}{l}\text { Insulin-induced } \\
\text { phosphorylation of AKT } \\
\text { and glucose uptake. } \\
\text { Glycerol release in } \\
\text { response to forskolin }\end{array}$ & $3 / 33$ & [176] \\
\hline Human iPSCs & $\begin{array}{l}\text { Days 0-2: bFGF. Days 2-5: RA. Days 5-11: } \\
\text { Primate ES cell medium. Days 11-14: } \\
\text { IBMX, Dex, Insulin, Pioglitazone }\end{array}$ & White & NR & $2 / 14$ & [233] \\
\hline Human iPSCs & $\begin{array}{c}\text { Days 0-2: 20\% KSR. Days 2-5: RA. Days } \\
\text { 6-8: 20\% KSR; Days 8-11: Insulin, } \\
\text { Pioglitazone. Days 11-14/16: IBMX, Dex, } \\
\text { Insulin, Pioglitazone }\end{array}$ & White & $\begin{array}{l}\text { Insulin-induced } \\
\text { phosphorylation of AKT. } \\
\text { Glycerol release in } \\
\text { response to forskolin }\end{array}$ & $2 / 14-16$ & [234] \\
\hline Human iPSCs & $\begin{array}{c}\text { Days 0-4: GlutaMAX, VitC, BMP4, activin } \\
\text { A. Days 4-10: } 10 \% \text { FCS, Insulin, IBMX, Dex, } \\
\text { Indomethacin. Days 10-20: } \\
10 \% \text { FCS, Insulin }\end{array}$ & Beige & $\begin{array}{c}\text { Insulin-induced } \\
\text { phosphorylation of AKT }\end{array}$ & $3 / 20$ & [186] \\
\hline Human iPSCs & $\begin{array}{l}\text { Days }-2-0 \text { : Serum-free MSC medium, } \\
\text { TGF- } \beta \text { inh, IL-4. Days } 0-3 \text { : Insulin, T3, } \\
\text { IBMX, Dex, Indomethacin, TGF- } \beta \text { inh, } \\
\text { Rosiglitazone. Days } 3-12 \text { : Insulin, T3, } \\
\text { TGF- } \beta \text { inh, Rosiglitazone; }\end{array}$ & Beige & $\begin{array}{l}\text { Insulin-induced } \\
\text { phosphorylation of AKT } \\
\text { and glucose uptake }\end{array}$ & $2 / 12$ & [239] \\
\hline Human iPSCs & $\begin{array}{c}\text { Days 0-3: 20\% KSR. Days 3-5: 20\% KSR, } \\
\text { RA; Days 6-20: 20\% KSR and } \\
\text { overexpression of C/EBP } \beta \text {. Days 20-30: } \\
\text { 10\% KSR, Insulin, IBMX, Dex, Rosiglitazone }\end{array}$ & $\begin{array}{l}\text { Brown and } \\
\text { white }\end{array}$ & NR & $2 / 30$ & [242] \\
\hline
\end{tabular}

KSR, knockout serum replacement; IBMX, 3-isobutyl-1-methylxanthine; Dex, Dexamethasone; RA, Retinoic acid T3, Triiodothyronine; FGF, Fibroblast growth factor; Dox, Doxycycline; FCS, fetal calf serum; NR, Not reported; $\downarrow$ decreased. 


\section{Future Prospects and Challenges}

Moving the iPSC-derived insulin/glucose-responsive cells from bench to bedside requires overcoming several obstacles. These range from iPSC reprogramming to transplantation of differentiated cells, as well as maintenance of phenotypic stability, and avoiding tumor formation.

\subsection{Reprogramming of $i P S C s$}

Most iPSCs are established utilizing retroviral vectors. There are numerous transgene integrations in the genomes of iPSCs developed by retroviral vectors, which may cause leaky expression that can interrupt the function of endogenous transcription factors or introduce mutations that increase tumorigenic risk after transplantation. Non-viral reprogramming methods reduce toxicity or other adverse effects of the vectors and their delivery systems, but their efficiency of iPSC induction is typically lower than that of retroviral vectors, possibly due to low transduction efficiency and unstable expression. Furthermore, all reprogramming strategies influence and impede cell cycle control genes, such as p53.

Variations in the iPSC lines strongly influence iPSC reprogramming and differentiation. Embryonic and tail-tip fibroblasts in mouse and skin fibroblast and peripheral blood cells in human are widely used for reprogramming, mainly due to their availability and relative ease of culture. Mouse tail-tip fibroblast iPSCs demonstrate high tumorigenic propensity, while that of gastric epithelialand hepatocyte-derived iPSCs is lower [243]. This indicates that the origin of the iPSCs influences the risk of tumor formation. A comprehensive study, using 28 iPSC lines derived from various somatic cells, demonstrated that the origin of cells, but not the derivation method, is the major determinant of variation in differentiation [244]. The iPSC clones derived from peripheral blood cells exhibit a high differentiation efficiency, while iPSC clones from skin fibroblasts demonstrate poor differentiation [244]. When comparing iPSCs from peripheral blood and skin fibroblasts from the same individuals, variations in cell differentiation are mainly due to donor differences, rather than to the original cell types [244]. The molecular mechanisms underlying this phenomenon are not yet fully understood, but it has been reported that in iPSCs derived from fibroblasts, mitochondrial numbers return to their pre-reprogrammed state, or even to lower levels, after redifferentiation [245]. In addition, epigenetic imprints of the somatic cell of origin are maintained in the iPSCs, affecting directed differentiation [246].

\subsection{Immaturity of the iPSC-Derived Insulin/Glucose-Responsive Cells}

Despite an increasing number of differentiation protocols, production of mature and functional iPSC-derived insulin/glucose-responsive cells is yet to be convincingly achieved. The final percentage of differentiated $\beta$-cells obtained in most studies without purification is at best $30-60 \%$. Most remaining cells are undifferentiated/unwanted cells. iPSC-derived $\beta$-like cells demonstrate increased basal insulin levels and insufficient glucose responsiveness. Furthermore, in vitro differentiation results in generation of heterogeneous cell populations, composed of bihormonal (insulin ${ }^{+} /$glucagon $^{+}$) cells alongside diverse categories of progenitor cells [53]. Similarly, most iPSC-derived hepatocytes/myotubes/adipocytes resemble more fetal and neonatal cells. These pieces of evidence indicate lack of additional in vivo factors in in vitro differentiation schemes. For example, after birth, $\beta$-cell function changes from amino acid- to glucose-dependent insulin secretion, which reflects the change in the nutritional environment. This adaptation is mediated by a shift in the sensitivity of mammalian target of rapamycin complex 1 (mTORC1) pathway to nutrients [247], which maintains the immature phenotype of the $\beta$-cells [248]. Incubation of human fetal $\beta$-cells in a mature-like environment (low amino acid concentrations) for four days, leads to a shift into glucose-responsive insulin-secreting cells; incubation of these cells in an immature-like environment (high amino acid concentrations) elicits insulin secretion in response to amino acids but not to glucose [247]. Therefore, growth factors and signaling molecules involved in the development of the pancreas, liver, skeletal muscle, and adipose tissue need to be better characterized 
to determine their potential to drive PSCs into differentiation of mature insulin/glucose-responsive cells in vitro.

Several modifications in recent differentiation protocols have been made to produce larger populations of mature insulin/glucose-responsive cells. Inhibition of the endogenous Wnt signaling in late stages potentially promotes the differentiation of iPSC-derived $\beta$-like cells toward a more mature phenotype [53]. Although Wnt signaling elicits different effects throughout the development of the pancreas [9], this signaling pathway seems to be more important during the initial stage than at the later stages of differentiation. It is required for promoting FGF expression, expansion of the pancreatic epithelium prior to differentiation, and also for terminal differentiation of acinar cells.

The circadian clock is yet another factor that should be considered when differentiating glucose/insulin-responsive cells in vitro. Entrainment to circadian feeding/fasting rhythms triggers maturation and function of PSC-derived $\beta$-cells, evidenced by rhythmic insulin responses and a rise in the glucose threshold for insulin secretion [93]. Circadian rhythms promote expression of enzymes involved in energy metabolism, including glucose transport and metabolism, TCA enzymes, as well as electron transport chain and ATP synthase components [93]. Circadian entrainment also induces maturity-linked factors along with the machinery involved in insulin secretion (secretogranins, synaptotagmins, and syntaxins) [93]. Rhythmic expression of these effectors is associated with greater/pulsatile GSIS responses [93].

Terminal differentiation seems to be feasible by combining factors promoting maturation and 3D differentiation systems. Cell-to-cell surface contacts and simultaneous paracrine signaling regulate cell differentiation. With culture of iPSCs in the presence of MSCs or human umbilical vein endothelial cells (HUVECs), paracrine soluble factors secreted by MSCs or HUVECs, even without cell-cell surface contact, are sufficient to induce hepatic differentiation [140]. However both cell-cell surface contact and paracrine soluble factors must co-exist to allow for the organization into a 3D liver organoid [140]. When both cell-cell surface contact and paracrine signals are in operation, the liver organoids demonstrate a gene expression profile similar to that of primary hepatocytes [140]. In co-culture combinations, mRNA levels of some hepatic markers are, however, lower than in primary hepatocytes, but albumin secretion is $\sim 2.5$-fold higher than hepatocyte-like cells induced from iPSCs alone [140].

Similarly, using a 3D culture system and a step-wise differentiation protocol, pancreatic clusters have been produced, containing $\alpha$ - and $\beta$-like cells, and enterochromaffin-like cells, as well as non-endocrine cell type [102]. Using enzymatic dissociation followed by re-aggregation after generation of endocrine progenitors to deplete non-endocrine cells, PSC-derived clusters, which contain up to $80 \%$ $\beta$-like cells were generated [102]. These highly purified PSC-derived clusters are glucose-responsive, and show elevated stimulation indices compared to unsorted, re-aggregated PSC-derived clusters in both static and dynamic GSIS-but still exhibit lower magnitude of secretion compared to cadaveric islets [102]. However, it must be noted that fractionating the differentiated pancreatic organoids into individual cells to obtain only $\beta$-cells would disrupt the architecture of the in vitro generated islets that is sought to recapitulate in vivo development, as cell-cell and cell-matrix contacts are crucial for $\beta$-cells to conferring its functional properties.

Standardization of iPSCs meets more difficulty when using patient-specific iPSCs. Insulin mutations impair differentiation of $\beta$-cells in a patient-derived iPSC model of neonatal diabetes and triggers ER-stress concomitantly with insulin expression [133]. Increased ER-stress causes reduced mTORC1 signaling and perturbs mitochondria, which are critical for $\beta$-cell proliferation and function [133]. Similarly, the differentiation of T1D iPSCs into insulin-producing $\beta$-cells exhibits lower efficiency compared to that of non-diabetic iPSCs, and differentiated cells express PDX1 poorly [91]. Effective differentiation of T1D iPSCs requires precise temporal modulation of demethylation; 5-Aza-2'-deoxycytidine (5-Aza-DC), a potent demethylating agent, which inhibits DNA methyltransferase, allows for the binding of the transcriptional machinery and promotes gene expression [91]. In addition, the use of a demethylation agent induces definitive endoderm cells expressing pancreatic $\beta$-cell-specific markers, and possessing insulin granules at similar levels to 
cadaveric $\beta$-cells; these cells are functional and glucose-responsive [91]. Furthermore, depending on the cell origin or derivation method, some iPSC lines show resistance to differentiation, variations in differentiation efficiency, or tumorigenicity. These variations seem to be due to epigenetic differences, variations in techniques used to generate or maintain iPSCs, or abnormalities in karyotype. Thus, choosing iPSC lines with minimal batch-to-batch variation in differentiation efficiency is required to overcome this differentiation challenge prior to use in specific cell therapies.

\subsection{Low Efficiency of Engraftment and Safety in Clinical Therapy}

Successful survival post-transplantation is another challenge, which can be attributed to the lack of suitable transplantation approaches and immune rejection in the host. To date, iPSC-derived insulin/glucose-responsive cells in vitro lack many properties of mature cells. Further maturation occurs in vivo after transplantation to immunodeficient mice. Therefore, more work is needed to understand what factors in the in vivo milieu are crucial for functional maturation. Factors may be provided by the in vivo niche at the transplantation site. Maturation develops more efficiently in female mice, indicating the potential role of estrogen in maturation [105]. While human iPSCs can be prepared from the patients themselves, it is still important to develop criteria for cells that can be used clinically. For example, the use of genetic material for reprogramming is still a concern. A recent approach to address this issue is the use of small and large molecules to generate proteinand chemically induced iPSCs, allowing the generation of "nonintegrated" iPSCs (reviewed in [249]). Immunogenicity can be overcome by using feeder-free culture systems, encapsulation of iPSCs, and also by use of xeno-free components in the media [250]. Encapsulation of iPSC-derived cells by semipermeable membrane devices further differentiates cells into mature cells, enhances survival from host immune responses, and reduces or eliminates the need for immunosuppressive agents [14,251,252]. In addition, the CRISPR-Cas9 system for gene editing enables the ablation of the highly polymorphic HLA class I and class II molecules, as well as expressing immunomodulatory factors, such as PD-L1, HLA-G, and CD47 [253,254]. The generation of these hypoimmunogenic human PSCs create "off-the-shelf" products for more wide-spread use.

After satisfying all these requirements, PSC-based therapies may show superiority to any other antidiabetic treatment strategies. Increasing medical expenditures, as a result of the rising prevalence of diabetes, will become an economic concern in the near future. Thus, prevention and treatment of diabetes are very important from a societal perspective. Indeed, restoring or maintaining the function of residual insulin/glucose-responsive cells prevents the progression of diabetes and reduces medical costs.

\section{Conclusions}

Generation of iPSC-derived insulin/glucose-responsive cells in vitro offers great opportunities for both in vitro disease modeling and treatment of diabetes in humans. There is continuous improvement of the differentiation protocols for ESCs and iPSCs, allowing for use in scalable in vitro generation of insulin/glucose-responsive cells, as well as in approaches for transplantation. Despite these advances, a more complete understanding of in vitro differentiation processes and maturation in vivo is required to generate properly functional and safe cells for replacement therapy. This is a pre-requisite for generation of large and sufficient quantities of insulin/glucose-responsive cells, and will also refine and improve in vitro disease models derived from iPSCs.

Supplementary Materials: The following are available online at http://www.mdpi.com/2073-4409/9/11/2465/s1, Table S1: Transcription factors associated with development of the pancreas.

Author Contributions: S.G. wrote the manuscript with input from all other authors. Tables and figures were prepared by S.G., T.S., and J.P.M.C.M.d.C. All authors have read and agreed to the published version of the manuscript.

Funding: The work was supported by European Union's Horizons 2020 research and innovation program under grant agreement No. 667191. It was also funded by Swedish Research Council (Dnr 2009-1039 to HMULDER; 
Dnr 2016-01495 to MFEX), a grant to LUDC-IRC (Dnr IRC15-0067), the Novo Nordisk (NNF18OC0034238 to HMULDER), and Swedish Diabetes Foundation (DIA2018-325 to HMULDER and DIA2019-460 to MFEX).

Conflicts of Interest: There is no conflict of interest.

\section{References}

1. International Diabetes Federation. IDF Diabetes Atlas, 9th ed.; International Diabetes Federation: Brussels, Belgium, 2019.

2. Gheibi, S.; Samsonov, A.P.; Gheibi, S.; Vazquez, A.B.; Kashfi, K. Regulation of carbohydrate metabolism by nitric oxide and hydrogen sulfide: Implications in diabetes. Biochem. Pharmacol. 2020, 176, 113819. [CrossRef] [PubMed]

3. Schiesser, J.V.; Wells, J.M. Generation of $\beta$ cells from human pluripotent Stem Cells: Are we there yet? Ann. N. Y. Acad. Science 2014, 1311, 124-137. [CrossRef] [PubMed]

4. Thakur, G.; Lee, H.-J.; Jeon, R.-H.; Lee, S.-L.; Rho, G.-J. Small Molecule-Induced Pancreatic $\beta$-Like Cell Development: Mechanistic Approaches and Available Strategies. Int. J. Mol. Science 2020, 21, 2388. [CrossRef] [PubMed]

5. Chal, J.; Pourquie, O. Making muscle: Skeletal myogenesis in vivo and in vitro. Development 2017, 144, 2104-2122. [CrossRef]

6. Higuchi, A.; Kumar, S.S.; Ling, Q.-D.; Alarfaj, A.A.; Munusamy, M.A.; Murugan, K.; Hsu, S.-T.; Benelli, G.; Umezawa, A. Polymeric design of cell culture materials that guide the differentiation of human pluripotent Stem Cells. Prog. Polym. Science 2017, 65, 83-126. [CrossRef]

7. Tran, R.; Moraes, C.; Hoesli, C.A. Controlled clustering enhances PDX1 and NKX6.1 expression in pancreatic endoderm cells derived from pluripotent Stem Cells. Sci. Rep. 2020, 10, 1-12. [CrossRef]

8. Chen, S.; Wang, J.; Ren, H.; Liu, Y.; Xiang, C.; Li, C.; Lu, S.; Shi, Y.; Deng, H.; Shi, X. Hepatic spheroids derived from human induced pluripotent Stem Cells in bio-artificial liver rescue porcine acute liver failure. Cell Res. 2020, 30, 95-97. [CrossRef]

9. Legøy, T.A.; Vethe, H.; Abadpour, S.; Strand, B.L.; Scholz, H.; Paulo, J.A.; Ræder, H.; Ghila, L.; Chera, S. Encapsulation boosts islet-cell signature in differentiating human induced pluripotent Stem Cells via integrin signalling. Sci. Rep. 2020, 10, 1-16. [CrossRef]

10. Calabrese, D.; Roma, G.; Bergling, S.; Carbone, W.; Mele, V.; Nuciforo, S.; Fofana, I.; Campana, B.; Szkolnicka, D.; Hay, D.C.; et al. Liver biopsy derived induced pluripotent Stem Cells provide unlimited supply for the generation of hepatocyte-like cells. PLoS ONE 2019, 14, e0221762. [CrossRef]

11. Haller, C.; Piccand, J.; De Franceschi, F.; Ohi, Y.; Bhoumik, A.; Boss, C.; De Marchi, U.; Jacot, G.; Metairon, S.; Descombes, P.; et al. Macroencapsulated Human iPSC-Derived Pancreatic Progenitors Protect against STZ-Induced Hyperglycemia in Mice. Stem Cell Rep. 2019, 12, 787-800. [CrossRef]

12. Halevy, T.; Urbach, A. Comparing ESC and iPSC-Based Models for Human Genetic Disorders. J. Clin. Med. 2014, 3, 1146-1162. [CrossRef] [PubMed]

13. Takahashi, K.; Yamanaka, S. Induction of Pluripotent Stem Cells from Mouse Embryonic and Adult Fibroblast Cultures by Defined Factors. Cell 2006, 126, 663-676. [CrossRef] [PubMed]

14. Yabe, S.G.; Fukuda, S.; Nishida, J.; Takeda, F.; Nashiro, K.; Okochi, H. Induction of functional islet-like cells from human iPS cells by suspension culture. Regen. Ther. 2019, 10, 69-76. [CrossRef] [PubMed]

15. Blelloch, R.; Venere, M.; Yen, J.; Ramalho-Santos, M. Generation of Induced Pluripotent Stem Cells in the Absence of Drug Selection. Cell Stem Cell 2007, 1, 245-247. [CrossRef] [PubMed]

16. Maherali, N.; Ahfeldt, T.; Rigamonti, A.; Utikal, J.; Cowan, C.; Hochedlinger, K. A High-Efficiency System for the Generation and Study of Human Induced Pluripotent Stem Cells. Cell Stem Cell 2008, 3, 340-345. [CrossRef]

17. Nakagawa, M.; Koyanagi, M.; Tanabe, K.; Takahashi, K.; Ichisaka, T.; Aoi, T.; Okita, K.; Mochiduki, Y.; Takizawa, N.; Yamanaka, S. Generation of induced pluripotent Stem Cells without Myc from mouse and human fibroblasts. Nat. Biotechnol. 2008, 26, 101-106. [CrossRef]

18. Okita, K.; Ichisaka, T.; Yamanaka, S. Generation of germline-competent induced pluripotent Stem Cells. Nat. Cell Biol. 2007, 448, 313-317. [CrossRef]

19. Wernig, M.; Meissner, A.; Cassady, J.P.; Jaenisch, R. c-Myc Is Dispensable for Direct Reprogramming of Mouse Fibroblasts. Cell Stem Cell 2008, 2, 10-12. [CrossRef] 
20. Okita, K.; Nakagawa, M.; Hyenjong, H.; Ichisaka, T.; Yamanaka, S. Generation of Mouse Induced Pluripotent Stem Cells Without Viral Vectors. Science 2008, 322, 949-953. [CrossRef]

21. Sommer, C.A.; Stadtfeld, M.; Murphy, G.J.; Hochedlinger, K.; Kotton, D.N.; Mostoslavsky, G. Induced Pluripotent Stem Cell Generation Using a Single Lentiviral Stem Cell Cassette. Stem Cells 2009, 27, 543-549. [CrossRef]

22. Woltjen, K.; Michael, I.P.; Mohseni, P.; Desai, R.; Mileikovsky, M.; Hämäläinen, R.; Cowling, R.; Wang, W.; Liu, P.; Gertsenstein, M.; et al. piggyBac transposition reprograms fibroblasts to induced pluripotent Stem Cells. Nat. Cell Biol. 2009, 458, 766-770. [CrossRef] [PubMed]

23. Yusa, K.; Rad, R.; Takeda, J.; Bradley, A. Generation of transgene-free induced pluripotent mouse Stem Cells by the piggyBac transposon. Nat. Methods 2009, 6, 363-369. [CrossRef] [PubMed]

24. Kumar, D.; Talluri, T.R.; Anand, T.; Kues, W.A. Transposon-based reprogramming to induced pluripotency. Histol. Histopathol. 2015, 30, 1397-1409. [PubMed]

25. Stadtfeld, M.; Nagaya, M.; Utikal, J.; Weir, G.; Hochedlinger, K. Induced Pluripotent Stem Cells Generated Without Viral Integration. Science 2008, 322, 945-949. [CrossRef] [PubMed]

26. Fusaki, N.; Ban, H.; Nishiyama, A.; Saeki, K.; Hasegawa, M. Efficient induction of transgene-free human pluripotent Stem Cells using a vector based on Sendai virus, an RNA virus that does not integrate into the host genome. Proc. Jpn. Acad. Ser. B 2009, 85, 348-362. [CrossRef] [PubMed]

27. Ban, H.; Nishishita, N.; Fusaki, N.; Tabata, T.; Saeki, K.; Shikamura, M.; Takada, N.; Inoue, M.; Hasegawa, M.; Kawamata, S.; et al. Efficient generation of transgene-free human induced pluripotent Stem Cells (iPSCs) by temperature-sensitive Sendai virus vectors. Proc. Natl. Acad. Sci. USA 2011, 108, 14234-14239. [CrossRef]

28. González, F.; Boué, S.; Belmonte, J.C.I. Methods for making induced pluripotent Stem Cells: Reprogramming à la carte. Nat. Rev. Genet. 2011, 12, 231-242. [CrossRef]

29. Gonzalez, F.; Monasterio, M.B.; Tiscornia, G.; Pulido, N.M.; Vassena, R.; Morera, L.B.; Piza, I.R.; Belmonte, J.C.I. Generation of mouse-induced pluripotent Stem Cells by transient expression of a single nonviral polycistronic vector. Proc. Natl. Acad. Sci. USA 2009, 106, 8918-8922. [CrossRef]

30. Rim, Y.A.; Nam, Y.; Park, N.; Jung, H.; Lee, K.; Lee, J.; Ju, J.H. Chondrogenic Differentiation from Induced Pluripotent Stem Cells Using Non-Viral Minicircle Vectors. Cells 2020, 9, 582. [CrossRef]

31. Yu, J.; Hu, K.; Smuga-Otto, K.; Tian, S.; Stewart, R.; Slukvin, I.I.; Thomson, J.A. Human Induced Pluripotent Stem Cells Free of Vector and Transgene Sequences. Science 2009, 324, 797-801. [CrossRef]

32. Okita, K.; Matsumura, Y.; Sato, Y.; Okada, A.; Morizane, A.; Okamoto, S.; Hong, H.; Nakagawa, M.; Tanabe, K.; Tezuka, K.-I.; et al. A more efficient method to generate integration-free human iPS cells. Nat. Methods 2011, 8, 409-412. [CrossRef] [PubMed]

33. Steinle, H.; Weber, M.; Behring, A.; Mau-Holzmann, U.; Schlensak, C.; Wendel, H.P.; Avci-Adali, M. Generation of iPSCs by Nonintegrative RNA-Based Reprogramming Techniques: Benefits of Self-Replicating RNA versus Synthetic mRNA. Stem Cells Int. 2019, 2019, 1-16. [CrossRef] [PubMed]

34. Warren, L.; Manos, P.D.; Ahfeldt, T.; Loh, Y.-H.; Li, H.; Lau, F.; Ebina, W.; Mandal, P.K.; Smith, Z.D.; Meissner, A.; et al. Highly Efficient Reprogramming to Pluripotency and Directed Differentiation of Human Cells with Synthetic Modified mRNA. Cell Stem Cell 2010, 7, 618-630. [CrossRef] [PubMed]

35. Zhou, H.; Wu, S.; Joo, J.Y.; Zhu, S.; Han, N.W.; Lin, T.; Trauger, S.; Bien, G.; Yao, S.; Zhu, Y.; et al. Generation of Induced Pluripotent Stem Cells Using Recombinant Proteins. Cell Stem Cell 2009, 4, 581. [CrossRef]

36. Michiue, H.; Tomizawa, K.; Wei, F.-Y.; Matsushita, M.; Lu, Y.-F.; Ichikawa, T.; Tamiya, T.; Date, I.; Matsui, H. The NH2Terminus of Influenza Virus Hemagglutinin-2 Subunit Peptides Enhances the Antitumor Potency of Polyarginine-mediated p53 Protein Transduction. J. Biol. Chem. 2004, 280, 8285-8289. [CrossRef] [PubMed]

37. Ichida, J.K.; Blanchard, J.; Lam, K.; Son, E.Y.; Chung, J.E.; Egli, D.; Loh, K.M.; Carter, A.C.; Di Giorgio, F.P.; Koszka, K.; et al. A small-molecule inhibitor of tgf-Beta signaling replaces sox 2 in reprogramming by inducing nanog. Cell Stem Cell 2009, 5, 491-503. [CrossRef]

38. Noggle, S.A.; Fung, H.-L.; Gore, A.; Martínez, H.; Satriani, K.C.; Prosser, R.; Oum, K.; Paull, D.; Druckenmiller, S.; Freeby, M.; et al. Human oocytes reprogram somatic cells to a pluripotent state. Nat. Cell Biol. 2011, 478, 70-75. [CrossRef]

39. Mali, P.; Chou, B.-K.; Yen, J.; Ye, Z.; Zou, J.; Dowey, S.; Brodsky, R.A.; Ohm, J.E.; Yu, W.; Baylin, S.B.; et al. Butyrate Greatly Enhances Derivation of Human Induced Pluripotent Stem Cells by Promoting Epigenetic Remodeling and the Expression of Pluripotency-Associated Genes. Stem Cells 2010, 28, 713-720. [CrossRef] 
40. Zhu, S.; Li, W.; Zhou, H.; Wei, W.; Ambasudhan, R.; Lin, T.; Kim, J.; Zhang, K.; Ding, S. Reprogramming of Human Primary Somatic Cells by OCT4 and Chemical Compounds. Cell Stem Cell 2010, 7, 651-655. [CrossRef]

41. Esteban, M.A.; Wang, T.; Qin, B.; Yang, J.; Qin, D.; Cai, J.; Li, W.; Weng, Z.; Chen, J.; Ni, S.; et al. Vitamin C Enhances the Generation of Mouse and Human Induced Pluripotent Stem Cells. Cell Stem Cell 2010, 6, 71-79. [CrossRef]

42. Huangfu, D.; Maehr, R.; Guo, W.; Eijkelenboom, A.; Snitow, M.; Chen, A.E.; Melton, D.A. Induction of pluripotent Stem Cells by defined factors is greatly improved by small-molecule compounds. Nat. Biotechnol. 2008, 26, 795-797. [CrossRef] [PubMed]

43. Vaskova, E.A.; Stekleneva, A.E.; Medvedev, S.P.; Zakian, S.M. “Epigenetic Memory” Phenomenon in Induced Pluripotent Stem Cells. Acta Nat. 2013, 5, 15-21. [CrossRef]

44. Bar-Nur, O.; Russ, H.A.; Efrat, S.; Benvenisty, N. Epigenetic Memory and Preferential Lineage-Specific Differentiation in Induced Pluripotent Stem Cells Derived from Human Pancreatic Islet Beta Cells. Cell Stem Cell 2011, 9, 17-23. [CrossRef] [PubMed]

45. Aasen, T.; Raya, A.; Barrero, M.J.; Garreta, E.; Consiglio, A.; Gonzalez, F.; Vassena, R.; Bilić, J.; Pekarik, V.; Tiscornia, G.; et al. Efficient and rapid generation of induced pluripotent Stem Cells from human keratinocytes. Nat. Biotechnol. 2008, 26, 1276-1284. [CrossRef] [PubMed]

46. Pictet, R.L.; Clark, W.R.; Williams, R.H.; Rutter, W.J. An ultrastructural analysis of the developing embryonic pancreas. Dev. Biol. 1972, 29, 436-467. [CrossRef]

47. Jennings, R.E.; Berry, A.A.; Strutt, J.P.; Gerrard, D.T.; Hanley, N.A. Human pancreas development. Development 2015, 142, 3126-3137. [CrossRef]

48. Jennings, R.E.; Berry, A.A.; Kirkwood-Wilson, R.; Roberts, N.A.; Hearn, T.; Salisbury, R.J.; Blaylock, J.; Hanley, K.P.; Hanley, N.A. Development of the Human Pancreas From Foregut to Endocrine Commitment. Diabetes 2013, 62, 3514-3522. [CrossRef]

49. Pan, F.C.; Wright, C. Pancreas organogenesis: From bud to plexus to gland. Dev. Dyn. 2011, 240, 530-565. [CrossRef]

50. Herrera, P.L. Adult insulin- and glucagon-producing cells differentiate from two independent cell lineages. Development 2000, 127, 2317-2322.

51. Larsen,H.L.; Grapin-Botton, A. The molecular and morphogenetic basis of pancreas organogenesis. Semin. Cell Dev. Biol. 2017, 66, 51-68. [CrossRef]

52. Dassaye, R.; Naidoo, S.; Cerf, M.E. Transcription factor regulation of pancreatic organogenesis, differentiation and maturation. Islets 2015, 8, 13-34. [CrossRef] [PubMed]

53. Vethe, H.; Ghila, L.; Berle, M.; Hoareau, L.; Haaland, Ø.A.; Scholz, H.; Paulo, J.A.; Chera, S.; Ræder, H. The Effect of Wnt Pathway Modulators on Human iPSC-Derived Pancreatic Beta Cell Maturation. Front. Endocrinol. 2019, 10, 293. [CrossRef] [PubMed]

54. Mochida, T.; Ueno, H.; Tsubooka-Yamazoe, N.; Hiyoshi, H.; Ito, R.; Matsumoto, H.; Toyoda, T. Insulin-Deficient Diabetic Condition Upregulates the Insulin-Secreting Capacity of Human Induced Pluripotent Stem Cell-Derived Pancreatic Endocrine Progenitor Cells After Implantation in Mice. Diabetes 2020, 69, 634-646. [CrossRef] [PubMed]

55. Tam, P.P.L.; Loebel, D.A.F. Gene function in mouse embryogenesis: Get set for gastrulation. Nat. Rev. Genet. 2007, 8, 368-381. [CrossRef] [PubMed]

56. Zhang, D.; Jiang, W.; Liu, M.; Sui, X.; Yin, X.; Chen, S.; Shi, Y.; Deng, H. Highly efficient differentiation of human ES cells and iPS cells into mature pancreatic insulin-producing cells. Cell Res. 2009, 19, 429-438. [CrossRef]

57. Nostro, M.C.; Sarangi, F.; Ogawa, S.; Holtzinger, A.; Corneo, B.; Li, X.; Micallef, S.J.; Park, I.-H.; Basford, C.; Wheeler, M.B.; et al. Stage-specific signaling through TGF $\beta$ family members and WNT regulates patterning and pancreatic specification of human pluripotent Stem Cells. Development 2011, 138, 1445. [CrossRef]

58. Teo, A.K.K.; Ali, Y.; Wong, K.Y.; Chipperfield, H.; Sadasivam, A.; Poobalan, Y.; Tan, E.K.; Wang, S.T.; Abraham, S.; Tsuneyoshi, N.; et al. Activin and BMP4 Synergistically Promote Formation of Definitive Endoderm in Human Embryonic Stem Cells. Stem Cells 2012, 30, 631-642. [CrossRef]

59. Ungrin, M.D.; Clarke, G.; Yin, T.; Niebrugge, S.; Nostro, M.C.; Sarangi, F.; Wood, G.; Keller, G.; Zandstra, P.W. Rational bioprocess design for human pluripotent stem cell expansion and endoderm differentiation based on cellular dynamics. Biotechnol. Bioeng. 2012, 109, 853-866. [CrossRef] 
60. Yabe, S.G.; Fukuda, S.; Takeda, F.; Nashiro, K.; Shimoda, M.; Okochi, H. Efficient generation of functional pancreatic $\beta$-cells from human induced pluripotent Stem Cells. J. Diabetes 2016, 9, 168-179. [CrossRef]

61. Wells, J.M.; A Melton, D. Early mouse endoderm is patterned by soluble factors from adjacent germ layers. Development 2000, 127, 1563-1572.

62. Deutsch, G.; Jung, J.; Zheng, M.; Lóra, J.; Zaret, K.S. A bipotential precursor population for pancreas and liver within the embryonic endoderm. Development 2001, 128, 871-881. [PubMed]

63. Ameri, J.; Ståhlberg, A.; Pedersen, J.; Johansson, J.K.; Johannesson, M.M.; Artner, I.; Semb, H. FGF2 Specifies hESC-Derived Definitive Endoderm into Foregut/Midgut Cell Lineages in a Concentration-Dependent Manner. Stem Cells 2009, 28, 45-56. [CrossRef] [PubMed]

64. Kelly, O.G.; Chan, M.Y.; Martinson, L.A.; Kadoya, K.; Ostertag, T.M.; Ross, K.G.; Richardson, M.; Carpenter, M.K.; D'Amour, K.A.; Kroon, E.; et al. Cell-surface markers for the isolation of pancreatic cell types derived from human embryonic Stem Cells. Nat. Biotechnol. 2011, 29, 750-756. [CrossRef] [PubMed]

65. Johannesson, M.; Ståhlberg, A.; Ameri, J.; Sand, F.W.; Norrman, K.; Semb, H. FGF4 and Retinoic Acid Direct Differentiation of hESCs into PDX1-Expressing Foregut Endoderm in a Time- and Concentration-Dependent Manner. PLoS ONE 2009, 4, e4794. [CrossRef] [PubMed]

66. Apelqvist, Å.; Ahlgren, U.; Edlund, H. Sonic hedgehog directs specialised mesoderm differentiation in the intestine and pancreas. Curr. Biol. 1997, 7, 801-804. [CrossRef]

67. Shahjalal, H.M.; Shiraki, N.; Sakano, D.; Kikawa, K.; Ogaki, S.; Baba, H.; Kume, K.; Kume, S. Generation of insulin-producing $\beta$-like cells from human iPS cells in a defined and completely xeno-free culture system. J. Mol. Cell Biol. 2014, 6, 394-408. [CrossRef] [PubMed]

68. Thatava, T.; Nelson, T.J.; Edukulla, R.; Sakuma, T.; Ohmine, S.; Tonne, J.M.; Yamada, S.; Kudva, Y.C.; Terzic, A.; Ikeda, Y. Indolactam V/GLP-1-mediated differentiation of human iPS cells into glucose-responsive insulin-secreting progeny. Gene Ther. 2011, 18, 283-293. [CrossRef]

69. Taylor, B.L.; Liu, F.-F.; Sander, M. Nkx6.1 Is Essential for Maintaining the Functional State of Pancreatic Beta Cells. Cell Rep. 2013, 4, 1262-1275. [CrossRef]

70. Memon, B.; Abdelalim, E.M. Stem Cell Therapy for Diabetes: Beta Cells versus Pancreatic Progenitors. Cells 2020, 9, 283. [CrossRef]

71. Aigha, I.I.; Memon, B.; Elsayed, A.K.; Abdelalim, E.M. Differentiation of human pluripotent Stem Cells into two distinct NKX6.1 populations of pancreatic progenitors. Stem Cell Res. Ther. 2018, 9, 1-11. [CrossRef]

72. Takeishi, K.; De L'Hortet, A.C.; Wang, Y.; Handa, K.; Guzman-Lepe, J.; Matsubara, K.; Morita, K.; Jang, S.; Haep, N.; Florentino, R.M.; et al. Assembly and Function of a Bioengineered Human Liver for Transplantation Generated Solely from Induced Pluripotent Stem Cells. Cell Rep. 2020, 31, 107711. [CrossRef] [PubMed]

73. Memon, B.; Karam, M.; Al-Khawaga, S.; Abdelalim, E.M. Enhanced differentiation of human pluripotent Stem Cells into pancreatic progenitors co-expressing PDX1 and NKX6. Stem. Cell Res. Ther. 2018, 9, 15. [CrossRef] [PubMed]

74. Nostro, M.C.; Sarangi, F.; Yang, C.; Holland, A.M.; Elefanty, A.G.; Stanley, E.G.; Greiner, D.L.; Keller, G. Efficient Generation of NKX6-1+ Pancreatic Progenitors from Multiple Human Pluripotent Stem Cell Lines. Stem Cell Rep. 2015, 4, 591-604. [CrossRef] [PubMed]

75. Memon, B.; Younis, I.; Abubaker, F.; Abdelalim, E.M. PDX1 - /NKX6.1 + progenitors derived from human pluripotent Stem Cells as a novel source of insulin-secreting cells. Diabetes/Metabolism Res. Rev. 2020, 3400. [CrossRef] [PubMed]

76. Rosado-Olivieri, E.A.; Anderson, K.; Kenty, J.H.; Melton, D.A. YAP inhibition enhances the differentiation of functional stem cell-derived insulin-producing $\beta$ cells. Nat. Commun. 2019, 10, 1-11. [CrossRef] [PubMed]

77. Hansen, C.G.; Moroishi, T.; Guan, K.-L. YAP and TAZ: A nexus for Hippo signaling and beyond. Trends Cell Biol. 2015, 25, 499-513. [CrossRef]

78. Rezania, A.; Bruin, J.E.; Arora, P.; Rubin, A.; Batushansky, I.; Asadi, A.; O’Dwyer, S.; Quiskamp, N.; Mojibian, M.; Albrecht, T.; et al. Reversal of diabetes with insulin-producing cells derived in vitro from human pluripotent Stem Cells. Nat. Biotechnol. 2014, 32, 1121-1133. [CrossRef]

79. Kunisada, Y.; Tsubooka-Yamazoe, N.; Shoji, M.; Hosoya, M. Small molecules induce efficient differentiation into insulin-producing cells from human induced pluripotent Stem Cells. Stem Cell Res. 2012, 8, 274-284. [CrossRef]

80. Miralles, F.; LaMotte, L.; Couton, D.; Joshi, R.L. Interplay between FGF10 and Notch signalling is required for the self-renewal of pancreatic progenitors. Int. J. Dev. Biol. 2006, 50, 17-26. [CrossRef] 
81. Bhushan, A.; Itoh, N.; Kato, S.; Thiery, J.P.; Czernichow, P.; Bellusci, S.; Scharfmann, R. Fgf10 is essential for maintaining the proliferative capacity of epithelial progenitor cells during early pancreatic organogenesis. Development 2001, 128, 5109-5117.

82. Hart, A.; Papadopoulou, S.; Edlund, H. Fgf10maintains notch activation, stimulates proliferation, and blocks differentiation of pancreatic epithelial cells. Dev. Dyn. 2003, 228, 185-193. [CrossRef] [PubMed]

83. Pinney, S.E.; Oliverkrasinski, J.M.; Ernst, L.M.; Hughes, N.; Patel, P.; Stoffers, D.A.; Russo, P.; De León, D.D. Neonatal Diabetes and Congenital Malabsorptive Diarrhea Attributable to a Novel Mutation in the Human Neurogenin-3 Gene Coding Sequence. J. Clin. Endocrinol. Metab. 2011, 96, 1960-1965. [CrossRef] [PubMed]

84. Gradwohl, G.; Dierich, A.; LeMeur, M.; Guillemot, F. neurogenin3 is required for the development of the four endocrine cell lineages of the pancreas. Proc. Natl. Acad. Sci. USA 2000, 97, 1607. [CrossRef]

85. Bliss, C.R.; Sharp, G.W. Glucose-induced insulin release in islets of young rats: Time-dependent potentiation and effects of 2-bromostearate. Am. J. Physiol. Metab. 1992, 263, E890-E896. [CrossRef] [PubMed]

86. Aguayo-Mazzucato, C.; Koh, A.; El Khattabi, I.; Li, W.-C.; Toschi, E.; Jermendy, A.; Juhl, K.; Mao, K.; Weir, G.C.; Sharma, A.; et al. Mafa expression enhances glucose-responsive insulin secretion in neonatal rat beta cells. Diabetologia 2010, 54, 583-593. [CrossRef]

87. Kataoka, K.; Han, S.I.; Shioda, S.; Hirai, M.; Nishizawa, M.; Handa, H. MafA is a glucose-regulated and pancreatic beta-cell-specific transcriptional activator for the insulin gene. J. Biol. Chem. 2002, 277, 49903-49910. [CrossRef] [PubMed]

88. Wang, H.; Brun, T.; Kataoka, K.; Sharma, A.J.; Wollheim, C.B. MAFA controls genes implicated in insulin biosynthesis and secretion. Diabetologia 2007, 50, 348-358. [CrossRef]

89. El Khattabi, I.; Sharma, A. Proper activation of MafA is required for optimal differentiation and maturation of pancreatic $\beta$-cells. Best Pr. Res. Clin. Endocrinol. Metab. 2015, 29, 821-831. [CrossRef]

90. Pagliuca, F.W.; Millman, J.R.; Gürtler, M.; Segel, M.; Van Dervort, A.; Ryu, J.H.; Peterson, Q.P.; Greiner, D.; Melton, D.A. Generation of Functional Human Pancreatic $\beta$ Cells In Vitro. Cell 2014, 159, 428-439. [CrossRef]

91. Manzar, G.S.; Kim, E.-M.; Zavazava, N. Demethylation of induced pluripotent Stem Cells from type 1 diabetic patients enhances differentiation into functional pancreatic $\beta$ cells. J. Biol. Chem. 2017, 292, 14066-14079. [CrossRef]

92. Davis, J.C.; Alves, T.C.; Helman, A.; Chen, J.C.; Kenty, J.H.; Cardone, R.L.; Liu, D.R.; Kibbey, R.G.; Melton, D.A. Glucose Response by Stem Cell-Derived $\beta$ Cells In Vitro Is Inhibited by a Bottleneck in Glycolysis. Cell Rep. 2020, 31, 107623. [CrossRef] [PubMed]

93. Alvarez-Dominguez, J.R.; Donaghey, J.; Rasouli, N.; Kenty, J.H.; Helman, A.; Charlton, J.; Straubhaar, J.R.; Meissner, A.; Melton, D.A. Circadian Entrainment Triggers Maturation of Human In Vitro Islets. Cell Stem Cell 2020, 26, 108-122.e10. [CrossRef] [PubMed]

94. Yoshihara, E.; Wei, Z.; Lin, C.S.; Fang, S.; Ahmadian, M.; Kida, Y.; Tseng, T.; Dai, Y.; Yasuyuki, K.; Liddle, C.; et al. ERR $\gamma$ Is Required for the Metabolic Maturation of Therapeutically Functional Glucose-Responsive $\beta$ Cells. Cell Metab. 2016, 23, 622-634. [CrossRef] [PubMed]

95. Liu, H.; Guo, D.; Ruzi, A.; Chen, Y.; Pan, T.; Yang, F.; Li, J.; Xu, K.; Zhou, T.; Qin, D.; et al. Testosterone improves the differentiation efficiency of insulin-producing cells from human induced pluripotent Stem Cells. PLoS ONE 2017, 12, e0179353. [CrossRef] [PubMed]

96. ElSharkawi, I.; Parambath, D.; Saber-Ayad, M.; Khan, A.A.; El-Serafi, A. Exploring the effect of epigenetic modifiers on developing insulin-secreting cells. Hum. Cell 2019, 33, 1-9. [CrossRef]

97. Ghazizadeh, Z.; Kao, D.-I.; Amin, S.; Cook, B.; Rao, S.; Zhou, T.; Zhang, T.; Xiang, Z.; Kenyon, R.; Kaymakcalan, O.; et al. ROCKII inhibition promotes the maturation of human pancreatic beta-like cells. Nat. Commun. 2017, 8, 1-12. [CrossRef]

98. Ameri, J.; Borup, R.; Prawiro, C.; Ramond, C.; Schachter, K.A.; Scharfmann, R.; Semb, H. Efficient Generation of Glucose-Responsive Beta Cells from Isolated GP2 + Human Pancreatic Progenitors. Cell Rep. 2017, 19, 36-49. [CrossRef]

99. Cogger, K.F.; Sinha, A.; Sarangi, F.; McGaugh, E.C.; Saunders, D.; Dorrell, C.; Mejia-Guerrero, S.; Aghazadeh, Y.; Rourke, J.L.; Screaton, R.A.; et al. Glycoprotein 2 is a specific cell surface marker of human pancreatic progenitors. Nat. Commun. 2017, 8,1-13. [CrossRef]

100. Jiang, W.; Sui, X.; Zhang, N.; Liu, M.; Ding, M.; Shi, Y.; Deng, H. CD24: A Novel Surface Marker for PDX1-Positive Pancreatic Progenitors Derived from Human Embryonic Stem Cells. Stem Cells 2011, 29, 609-617. [CrossRef] 
101. Ramond, C.; Glaser, N.; Berthault, C.; Ameri, J.; Kirkegaard, J.S.; Hansson, M.; Honoré, C.; Semb, H.; Scharfmann, R. Reconstructing human pancreatic differentiation by mapping specific cell populations during development. eLife 2017, 6, 6. [CrossRef]

102. Veres, A.; Faust, A.L.; Bushnell, H.L.; Engquist, E.N.; Kenty, J.H.-R.; Harb, G.; Poh, Y.-C.; Sintov, E.; Gürtler, M.; Pagliuca, F.W.; et al. Charting cellular identity during human in vitro $\beta$-cell differentiation. Nat. Cell Biol. 2019, 569, 368-373. [CrossRef] [PubMed]

103. Rodriguez-Diaz, R.; Caicedo, A. Neural control of the endocrine pancreas. Best Pr. Res. Clin. Endocrinol. Metab. 2014, 28, 745-756. [CrossRef] [PubMed]

104. Aguayo-Mazzucato, C.; Dilenno, A.; Hollister-Lock, J.; Cahill, C.; Sharma, A.; Weir, G.; Colton, C.; Bonner-Weir, S. MAFA and T3 Drive Maturation of Both Fetal Human Islets and Insulin-Producing Cells Differentiated From hESC. J. Clin. Endocrinol. Metab. 2015, 100, 3651-3659. [CrossRef] [PubMed]

105. Saber, N.; E Bruin, J.; O’Dwyer, S.; Schuster, H.; Rezania, A.; Kieffer, T.J. Sex Differences in Maturation of Human Embryonic Stem Cell-Derived $\beta$ Cells in Mice. Endocrinology 2018, 159, 1827-1841. [CrossRef]

106. Briant, L.J.B.; Reinbothe, T.M.; Spiliotis, I.; Miranda, C.; Rodriguez, B.; Rorsman, P. $\delta$-cells and $\beta$-cells are electrically coupled and regulate $\alpha$-cell activity via somatostatin. J. Physiol. 2018, 596, 197-215. [CrossRef]

107. Alessandra, G.; Algerta, M.; Paola, M.; Carsten, S.; Cristina, L.; Paolo, M.; Elisa, M.; Gabriella, T.; Carla, P.; Galli, A.; et al. Shaping Pancreatic $\beta$-Cell Differentiation and Functioning: The Influence of Mechanotransduction. Cells 2020, 9, 413. [CrossRef]

108. Kechagia, J.Z.; Ivaska, J.; Roca-Cusachs, P. Integrins as biomechanical sensors of the microenvironment. Nat. Rev. Mol. Cell Biol. 2019, 20, 457-473. [CrossRef]

109. Ladoux, B.; Mège, R.-M. Mechanobiology of collective cell behaviours. Nat. Rev. Mol. Cell Biol. 2017, 18, 743-757. [CrossRef]

110. Mui, K.L.; Chen, C.S.; Assoian, R.K. The mechanical regulation of integrin-cadherin crosstalk organizes cells, signaling and forces. J. Cell Sci. 2016, 129, 1093-1100. [CrossRef]

111. Nyitray, C.E.; Chavez, M.G.; Desai, T.A. Compliant 3D Microenvironment Improves $\beta$-Cell Cluster Insulin Expression Through Mechanosensing and $\beta$-Catenin Signaling. Tissue Eng. Part A 2014, 20, 1888-1895. [CrossRef]

112. Ribeiro, D.; Kvist, A.J.; Wittung-Stafshede, P.; Hicks, R.; Forslöw, A. 3D-Models of Insulin-Producing $\beta$-Cells: From Primary Islet Cells to Stem Cell-Derived Islets. Stem Cell Rev. Rep. 2017, 14, 177-188. [CrossRef] [PubMed]

113. Galli, A.; Maffioli, E.; Sogne, E.; Moretti, S.; Di Cairano, E.S.; Negri, A.; Nonnis, S.; Norata, G.D.; Bonacina, F.; Borghi, F.; et al. Cluster-assembled zirconia substrates promote long-term differentiation and functioning of human islets of Langerhans. Sci. Rep. 2018, 8, 9979. [CrossRef] [PubMed]

114. Parnaud, G.; Lavallard, V.; Bédat, B.; Matthey-Doret, D.; Morel, P.; Berney, T.; Bosco, D. Cadherin Engagement Improves Insulin Secretion of Single Human $\beta$-Cells. Diabetes 2014, 64, 887-896. [CrossRef] [PubMed]

115. Charollais, A.; Gjinovci, A.; Huarte, J.; Bauquis, J.; Nadal, A.; Martín, F.; Andreu, E.; Sánchez-Andrés, J.V.; Calabrese, A.; Bosco, D.; et al. Junctional communication of pancreatic $\beta$ cells contributes to the control of insulin secretion and glucose tolerance. J. Clin. Investig. 2000, 106, 235-243. [CrossRef] [PubMed]

116. Di Cairano, E.S.; Moretti, S.; Marciani, P.; Sacchi, V.F.; Castagna, M.; Davalli, A.M.; Folli, F.; Perego, C. Neurotransmitters and Neuropeptides: New Players in the Control of Islet of Langerhans' Cell Mass and Function. J. Cell. Physiol. 2016, 231, 756-767. [CrossRef] [PubMed]

117. Arous, C.; Wehrle-Haller, B. Role and impact of the extracellular matrix on integrin-mediated pancreatic $\beta$-cell functions. Biol. Cell 2017, 109, 223-237. [CrossRef]

118. Caicedo, A. Paracrine and autocrine interactions in the human islet: More than meets the eye. Semin. Cell Dev. Biol. 2013, 24, 11-21. [CrossRef]

119. Barker, C.J.; Leibiger, I.B.; Berggren, P.-O. The pancreatic islet as a signaling hub. Adv. Biol. Regul. 2013, 53, 156-163. [CrossRef]

120. Lammert, E.; Cleaver, O.; Melton, D. Role of endothelial cells in early pancreas and liver development. Mech. Dev. 2003, 120, 59-64. [CrossRef]

121. Athirasala, A.; Hirsch, N.; Buxboim, A. Nuclear mechanotransduction: Sensing the force from within. Curr. Opin. Cell Biol. 2017, 46, 119-127. [CrossRef] 
122. Mamidi, A.; Prawiro, C.; Seymour, P.A.; De Lichtenberg, K.H.; Jackson, A.; Serup, P.; Semb, H. Mechanosignalling via integrins directs fate decisions of pancreatic progenitors. Nat. Cell Biol. 2018, 564, 114-118. [CrossRef] [PubMed]

123. Nair, G.G.; Liu, J.S.; Russ, H.A.; Tran, S.; Saxton, M.S.; Chen, R.; Juang, C.; Li, M.; Nguyen, V.Q.; Giacometti, S.; et al. Recapitulating endocrine cell clustering in culture promotes maturation of human stem-cell-derived beta cells. Nat. Cell Biol. 2019, 21, 263-274. [CrossRef] [PubMed]

124. Velazco-Cruz, L.; Song, J.; Maxwell, K.G.; Goedegebuure, M.M.; Augsornworawat, P.; Hogrebe, N.J.; Millman, J.R. Acquisition of Dynamic Function in Human Stem Cell-Derived beta Cells. Stem Cell Rep. 2019, 12, 351-365. [CrossRef] [PubMed]

125. Hogrebe, N.J.; Augsornworawat, P.; Maxwell, K.G.; Velazco-Cruz, L.; Millman, J.R. Targeting the cytoskeleton to direct pancreatic differentiation of human pluripotent Stem Cells. Nat. Biotechnol. 2020, 38, 460-470. [CrossRef]

126. Mahajan, A.; Taliun, D.; Thurner, M.; Robertson, N.R.; Torres, J.M.; Rayner, N.W.; Payne, A.J.; Steinthorsdottir, V.; Scott, R.A.; Grarup, N.; et al. Fine-mapping type 2 diabetes loci to single-variant resolution using high-density imputation and islet-specific epigenome maps. Nat. Genet. 2018, 50, 1505-1513. [CrossRef]

127. McCarthy, M.I. Genomics, Type 2 Diabetes, and Obesity. N. Engl. J. Med. 2010, 363, 2339-2350. [CrossRef]

128. Maehr, R.; Chen, S.; Snitow, M.; Ludwig, T.; Yagasaki, L.; Goland, R.; Leibel, R.L.; Melton, D.A. Generation of pluripotent Stem Cells from patients with type 1 diabetes. Proc. Natl. Acad. Sci. USA 2009, 106, 15768-15773. [CrossRef]

129. Ohmine, S.; Squillace, K.A.; Hartjes, K.A.; Deeds, M.C.; Armstrong, A.S.; Thatava, T.; Sakuma, T.; Terzic, A.; Kudva, Y.; Ikeda, Y. Reprogrammed keratinocytes from elderly type 2 diabetes patients suppress senescence genes to acquire induced pluripotency. Aging 2012, 4, 60-73. [CrossRef]

130. Zhao, T.; Zhang, Z.-N.; Rong, Z.; Xu, Y. Immunogenicity of induced pluripotent Stem Cells. Nat. Cell Biol. 2011, 474, 212-215. [CrossRef]

131. Tang, C.; Weissman, I.L.; Drukker, M. Immunogenicity of in vitro maintained and matured populations: Potential barriers to engraftment of human pluripotent stem cell derivatives. In Embryonic Stem Cell Immunobiology. Methods in Molecular Biology; Zavazava, N., Ed.; Springer Science and Business Media LLC: Totowa, NJ, USA, 2013; Volume 1029, pp. 17-31. [CrossRef]

132. Millman, J.R.; Xie, C.; Van Dervort, A.; Gürtler, M.; Pagliuca, F.W.; Melton, D.A. Generation of stem cell-derived $\beta$-cells from patients with type 1 diabetes. Nat. Commun. 2016, 7, 11463. [CrossRef]

133. Balboa, D.; Saarimäki-Vire, J.; Borshagovski, D.; Survila, M.; Lindholm, P.; Galli, E.; Eurola, S.; Ustinov, J.; Grym, H.; Huopio, H.; et al. Insulin mutations impair beta-cell development in a patient-derived iPSC model of neonatal diabetes. eLife 2018, 7, 7. [CrossRef] [PubMed]

134. Martin, B.C.; Warram, J.H.; Rosner, B.; Rich, S.S.; Soeldner, J.S.; Krolewski, A.S. Familial clustering of insulin sensitivity. Diabetes 1992, 41, 850-854. [CrossRef] [PubMed]

135. Shulman, R.G. Nuclear Magnetic Resonance Studies of Glucose Metabolism in Non-Insulin-Dependent Diabetes Mellitus Subjects. Mol. Med. 1996, 2, 533-540. [CrossRef] [PubMed]

136. Shin, D.; Monga, S.P. Cellular and Molecular Basis of Liver Development. Compr. Physiol. 2013, 3, $799-815$. [CrossRef] [PubMed]

137. Ober, E.A.; Lemaigre, F.P. Development of the liver: Insights into organ and tissue morphogenesis. J. Hepatol. 2018, 68, 1049-1062. [CrossRef] [PubMed]

138. Carpentier, A.; Nimgaonkar, I.; Chu, V.; Xia, Y.; Hu, Z.; Liang, T.J. Hepatic differentiation of human pluripotent Stem Cells in miniaturized format suitable for high-throughput screen. Stem Cell Res. 2016, 16, 640-650. [CrossRef] [PubMed]

139. Varghese, D.S.; Alawathugoda, T.T.; Ansari, S.A. Fine Tuning of Hepatocyte Differentiation from Human Embryonic Stem Cells: Growth Factor vs. Small Molecule-Based Approaches. Stem Cells Int. 2019, 2019, 1-18. [CrossRef] [PubMed]

140. Asai, A.; Aihara, E.; Watson, C.; Mourya, R.; Mizuochi, T.; Shivakumar, P.; Phelan, K.; Mayhew, C.; Helmrath, M.; Takebe, T.; et al. Paracrine signals regulate human liver organoid maturation from induced pluripotent Stem Cells. Development 2017, 144, 1056-1064. [CrossRef] 
141. Balasiddaiah, A.; Moreno, D.; Guembe, L.; Prieto, J.; Aldabe, R. Hepatic differentiation of mouse iPS cells and analysis of liver engraftment potential of multistage iPS progeny. J. Physiol. Biochem. 2013, 69, 835-845. [CrossRef]

142. Goulart, E.; De Caires-Junior, L.C.; Telles-Silva, K.A.; Araujo, B.H.S.; Rocco, S.A.; Sforca, M.; De Sousa, I.L.; Kobayashi, G.S.; Musso, C.M.; Assoni, A.F.; et al. 3D bioprinting of liver spheroids derived from human induced pluripotent Stem Cells sustain liver function and viability in vitro. Biofabrication 2019, 12, 015010. [CrossRef]

143. Goulart, E.; De Caires-Junior, L.C.; Telles-Silva, K.A.; Araujo, B.H.S.; Kobayashi, G.S.; Musso, C.M.; Assoni, A.F.; Oliveira, D.; Caldini, E.; Gerstenhaber, J.A.; et al. Adult and iPS-derived non-parenchymal cells regulate liver organoid development through differential modulation of Wnt and TGF- $\beta$. Stem Cell Res. Ther. 2019, 10, 1-11. [CrossRef] [PubMed]

144. McLean, A.B.; D’Amour, K.A.; Jones, K.L.; Krishnamoorthy, M.; Kulik, M.J.; Reynolds, D.M.; Sheppard, A.M.; Liu, H.; Xu, Y.; Baetge, E.E.; et al. Activin A Efficiently Specifies Definitive Endoderm from Human Embryonic Stem Cells Only When Phosphatidylinositol 3-Kinase Signaling Is Suppressed. Stem Cells 2007, 25, $29-38$. [CrossRef] [PubMed]

145. Massumi, M.; Pourasgari, F.; Nalla, A.; Batchuluun, B.; Nagy, K.; Neely, E.; Gull, R.; Nagy, A.; Wheeler, M.B. An Abbreviated Protocol for In Vitro Generation of Functional Human Embryonic Stem Cell-Derived Beta-Like Cells. PLoS ONE 2016, 11, e0164457. [CrossRef] [PubMed]

146. Rashidi,H.; Luu, N.-T.; Alwahsh, S.M.; Ginai, M.; Alhaque, S.; Dong, H.; Tomaz, R.A.; Vernay, B.; Vigneswara, V.; Hallett, J.M.; et al. 3D human liver tissue from pluripotent Stem Cells displays stable phenotype in vitro and supports compromised liver function in vivo. Arch. Toxicol. 2018, 92, 3117-3129. [CrossRef]

147. Cho, Y.M.; Lim, J.M.; Yoo, D.H.; Kim, J.H.; Chung, S.S.; Park, S.G.; Kim, T.H.; Oh, S.K.; Choi, Y.M.; Moon, S.Y.; et al. Betacellulin and nicotinamide sustain PDX1 expression and induce pancreatic beta-cell differentiation in human embryonic Stem Cells. Biochem. Biophys. Res. Commun. 2008, 366, 129-134. [CrossRef]

148. Swartz, E.W.; Baek, J.; Pribadi, M.; Wojta, K.J.; Almeida, S.; Karydas, A.; Gao, F.-B.; Miller, B.L.; Coppola, G. A Novel Protocol for Directed Differentiation of C9orf72-Associated Human Induced Pluripotent Stem Cells Into Contractile Skeletal Myotubes. Stem Cells Transl. Med. 2016, 5, 1461-1472. [CrossRef]

149. Takeuchi, H.; Nakatsuji, N.; Suemori, H. Endodermal differentiation of human pluripotent Stem Cells to insulin-producing cells in 3D culture. Sci. Rep. 2014, 4, 4488. [CrossRef]

150. Kim, S.K.; Melton, U.A. Pancreas development is promoted by cyclopamine, a Hedgehog signaling inhibitor. Proc. Natl. Acad. Sci. USA 1998, 95, 13036-13041. [CrossRef]

151. D'Amour, K.A.; Bang, A.G.; Eliazer, S.; Kelly, O.G.; Agulnick, A.D.; Smart, N.G.; Moorman, M.A.; Kroon, E.; Carpenter, M.K.; Baetge, E.E. Production of pancreatic hormone-expressing endocrine cells from human embryonic Stem Cells. Nat. Biotechnol. 2006, 24, 1392-1401. [CrossRef]

152. Kim, Y.; Kim, H.; Ko, U.H.; Oh, Y.; Lim, A.; Sohn, J.-W.; Shin, J.H.; Kim, H.; Han, Y.-M. Islet-like organoids derived from human pluripotent Stem Cells efficiently function in the glucose responsiveness in vitro and in vivo. Sci. Rep. 2016, 6, 35145. [CrossRef]

153. Scott, M.A.; Nguyen, V.T.; Levi, B.; James, A.W. Current Methods of Adipogenic Differentiation of Mesenchymal Stem Cells. Stem Cells Dev. 2011, 20, 1793-1804. [CrossRef] [PubMed]

154. Czysz, K.; Minger, S.; Thomas, N. DMSO Efficiently Down Regulates Pluripotency Genes in Human Embryonic Stem Cells during Definitive Endoderm Derivation and Increases the Proficiency of Hepatic Differentiation. PLoS ONE 2015, 10, e0117689. [CrossRef] [PubMed]

155. Siller, R.; Greenhough, S.; Naumovska, E.; Sullivan, G.J. Small-Molecule-Driven Hepatocyte Differentiation of Human Pluripotent Stem Cells. Stem Cell Rep. 2015, 4, 939-952. [CrossRef] [PubMed]

156. Zhou, J.; Wang, X.; Pineyro, M.A.; Egan, J.M. Glucagon-like peptide 1 and exendin-4 convert pancreatic AR42J cells into glucagon- and insulin-producing cells. Diabetes 1999, 48, 2358-2366. [CrossRef] [PubMed]

157. Korostylev, A.; Mahaddalkar, P.U.; Keminer, O.; Hadian, K.; Schorpp, K.; Gribbon, P.; Lickert, H. A high-content small molecule screen identifies novel inducers of definitive endoderm. Mol. Metab. 2017, 6, 640-650. [CrossRef]

158. McGaugh, E.C.; Nostro, M.C. Efficient Differentiation of Pluripotent Stem Cells to NKX6-1+ Pancreatic Progenitors. J. Vis. Exp. 2017, 2017. [CrossRef] 
159. Shim, J.-H.; Kim, J.; Han, J.; An, S.Y.; Jang, Y.J.; Son, J.; Woo, N.-H.; Kim, S.-K.; Kim, J.S. Pancreatic Islet-Like Three-Dimensional Aggregates Derived from Human Embryonic Stem Cells Ameliorate Hyperglycemia in Streptozotocin-Induced Diabetic Mice. Cell Transplant. 2015, 24, 2155-2168. [CrossRef]

160. Iovino, S.; Burkart, A.M.; Warren, L.; Patti, M.E.; Kahn, C.R. Myotubes derived from human-induced pluripotent Stem Cells mirror in vivo insulin resistance. Proc. Natl. Acad. Sci. USA 2016, 113, 1889-1894. [CrossRef]

161. Tanaka, A.; Woltjen, K.; Miyake, K.; Hotta, A.; Ikeya, M.; Yamamoto, T.; Nishino, T.; Shoji, E.; Sehara-Fujisawa, A.; Manabe, Y.; et al. Efficient and reproducible myogenic differentiation from human iPS cells: Prospects for modeling Miyoshi Myopathy in vitro. PLoS ONE 2013, 8, e61540. [CrossRef]

162. Sullivan, G.J.; Hay, D.C.; Park, I.-H.; Fletcher, J.; Hannoun, Z.; Payne, C.M.; Dalgetty, D.; Black, J.R.; Ross, J.A.; Samuel, K.; et al. Generation of functional human hepatic endoderm from human induced pluripotent Stem Cells. Hepatology 2010, 51, 329-335. [CrossRef]

163. Du, C.; Feng, Y.; Qiu, D.; Xu, Y.; Pang, M.; Cai, N.; Xiang, A.P.; Zhang, Q. Highly efficient and expedited hepatic differentiation from human pluripotent Stem Cells by pure small-molecule cocktails. Stem Cell Res. Ther. 2018, 9, 1-15. [CrossRef] [PubMed]

164. Wang, X.; You, L.; Cui, X.; Li, Y.; Wang, X.; Xu, P.; Zhu, L.; Wen, J.; Pang, L.; Guo, X.; et al. Evaluation and optimization of differentiation conditions for human primary brown adipocytes. Sci. Rep. 2018, 8, 1-12. [CrossRef] [PubMed]

165. Borowiak, M.; Maehr, R.; Chen, S.; Chen, A.E.; Tang, W.; Fox, J.L.; Schreiber, S.L.; Melton, D.A. Small Molecules Efficiently Direct Endodermal Differentiation of Mouse and Human Embryonic Stem Cells. Cell Stem Cell 2009, 4, 348-358. [CrossRef] [PubMed]

166. Chal, J.; Al Tanoury, Z.; Hestin, M.; Gobert, B.; Aivio, S.; Hick, A.; Cherrier, T.; Nesmith, A.P.; Parker, K.K.; Pourquié, $\mathrm{O}$. Generation of human muscle fibers and satellite-like cells from human pluripotent Stem Cells in vitro. Nat. Protoc. 2016, 11, 1833-1850. [CrossRef]

167. Chen, S.; Borowiak, M.; Fox, J.L.; Maehr, R.; Osafune, K.; Davidow, L.S.; Lam, K.; Peng, L.F.; Schreiber, S.L.; Rubin, L.L.; et al. A small molecule that directs differentiation of human ESCs into the pancreatic lineage. Nat. Chem. Biol. 2009, 5, 258-265. [CrossRef]

168. Wang, Q.; Donelan, W.; Ye, H.; Jin, Y.; Lin, Y.; Wu, X.; Wang, Y.; Xi, Y. Real-time observation of pancreatic beta cell differentiation from human induced pluripotent Stem Cells. Am. J. Transl. Res. 2019, 11, 3490-3504.

169. Van Der Wal, E.; Herrero-Hernandez, P.; Wan, R.; Broeders, M.; Groen, S.L.; Van Gestel, T.J.; Van Ijcken, W.F.; Cheung, T.H.; Van Der Ploeg, A.T.; Schaaf, G.J.; et al. Large-Scale Expansion of Human iPSC-Derived Skeletal Muscle Cells for Disease Modeling and Cell-Based Therapeutic Strategies. Stem Cell Rep. 2018, 10, 1975-1990. [CrossRef]

170. A Russ, H.; Parent, A.V.; Ringler, J.J.; Hennings, T.G.; Nair, G.G.; Shveygert, M.; Guo, T.; Puri, S.; Haataja, L.; Cirulli, V.; et al. Controlled induction of human pancreatic progenitors produces functional beta-like cells in vitro. EMBO J. 2015, 34, 1759-1772. [CrossRef]

171. Tan, M.; Jiang, L.; Li, Y.; Jiang, W. Dual Inhibition of BMP and WNT Signals Promotes Pancreatic Differentiation from Human Pluripotent Stem Cells. Stem Cells Int. 2019, 2019, 1-15. [CrossRef]

172. Zhu, Z.; Chew-Li, S.; Lee, K.; Rosen, B.P.; González, F.; Soh, C.-L.; Huangfu, D. Genome Editing of Lineage Determinants in Human Pluripotent Stem Cells Reveals Mechanisms of Pancreatic Development and Diabetes. Cell Stem Cell 2016, 18, 755-768. [CrossRef]

173. Tomizawa, M.; Shinozaki, F.; Motoyoshi, Y.; Sugiyama, T.; Yamamoto, S.; Ishige, N. Improved Survival and Initiation of Differentiation of Human Induced Pluripotent Stem Cells to Hepatocyte-Like Cells upon Culture in William's E Medium followed by Hepatocyte Differentiation Inducer Treatment. PLoS ONE 2016, 11, e0153435. [CrossRef] [PubMed]

174. Si-Tayeb, K.; Noto, F.K.; Nagaoka, M.; Li, J.; Battle, M.A.; Duris, C.; North, P.E.; Dalton, S.; Duncan, S.A. Highly efficient generation of human hepatocyte-like cells from induced pluripotent Stem Cells. Hepatology 2010, 51, 297-305. [CrossRef] [PubMed]

175. Sandouk, T.; Reda, D.; Hofmann, C. Antidiabetic agent pioglitazone enhances adipocyte differentiation of 3T3-F442A cells. Am. J. Physiol. Physiol. 1993, 264, C1600-C1608. [CrossRef] [PubMed]

176. Ahfeldt, T.; Schinzel, R.T.; Lee, Y.-K.; Hendrickson, D.; Kaplan, A.; Lum, D.H.; Camahort, R.; Xia, F.; Shay, J.; Rhee, E.P.; et al. Programming human pluripotent Stem Cells into white and brown adipocytes. Nat. Cell Biol. 2012, 14, 209-219. [CrossRef] 
177. Pezzolla, D.; López-Beas, J.; Lachaud, C.C.; Domínguez-Rodríguez, A.; Smani, T.; Hmadcha, A.; Soria, B. Resveratrol ameliorates the maturation process of beta-cell-like cells obtained from an optimized differentiation protocol of human embryonic Stem Cells. PLOS ONE 2015, 10, e0119904. [CrossRef]

178. Lorberbaum, D.S.; Kishore, S.; Rosselot, C.; Sarbaugh, D.; Brooks, E.P.; Aragon, E.; Xuan, S.; Simon, O.; Ghosh, D.; Mendelsohn, C.; et al. Retinoic acid signaling within pancreatic endocrine progenitors regulates mouse and human beta cell specification. Development 2020, 147. [CrossRef]

179. Öström, M.; Loffler, K.A.; Edfalk, S.; Selander, L.; Dahl, U.; Ricordi, C.; Jeon, J.; Correa-Medina, M.; Diez, J.; Edlund, H. Retinoic acid promotes the generation of pancreatic endocrine progenitor cells and their further differentiation into beta-cells. PLoS ONE 2008, 3, e2841. [CrossRef]

180. Villarroya, J.; Giralt, M.; Iglesias, R. Retinoids and adipose tissues: Metabolism, cell differentiation and gene expression. Int. J. Obes. 1999, 23, 1-6. [CrossRef]

181. Fayyad, A.M.; Khan, A.A.; Abdallah, S.H.; Alomran, S.S.; Bajou, K.; Khattak, M.N.K. Rosiglitazone Enhances Browning Adipocytes in Association with MAPK and PI3-K Pathways During the Differentiation of Telomerase-Transformed Mesenchymal Stromal Cells into Adipocytes. Int. J. Mol. Sci. 2019, 20, 1618. [CrossRef]

182. Ren, M.; Yan, L.; Shang, C.; Cao, J.; Min, J.; Cheng, H.; Lu, L.-H. Effects of sodium butyrate on the differentiation of pancreatic and hepatic progenitor cells from mouse embryonic Stem Cells. J. Cell. Biochem. 2009, 109, 236-244. [CrossRef]

183. Kondo, Y.; Toyoda, T.; Ito, R.; Funato, M.; Hosokawa, Y.; Matsui, S.; Sudo, T.; Nakamura, M.; Okada, C.; Zhuang, X.; et al. Identification of a small molecule that facilitates the differentiation of human iPSCs/ESCs and mouse embryonic pancreatic explants into pancreatic endocrine cells. Diabetologia 2017, 60, 1454-1466. [CrossRef] [PubMed]

184. Zhu, S.; Wurdak, H.; Wang, J.; Lyssiotis, C.A.; Peters, E.C.; Cho, C.Y.; Wu, X.; Schultz, P.G. A Small Molecule Primes Embryonic Stem Cells for Differentiation. Cell Stem Cell 2009, 4, 416-426. [CrossRef] [PubMed]

185. Chandra, V.; Phadnis, S.; Nair, P.D.; Bhonde, R.R. Generation of Pancreatic Hormone-Expressing Islet-Like Cell Aggregates from Murine Adipose Tissue-Derived Stem Cells. Stem Cells 2009, 27, 1941-1953. [CrossRef] [PubMed]

186. Guénantin, A.-C.; Briand, N.; Capel, E.; Dumont, F.; Morichon, R.; Provost, C.; Stillitano, F.; Jeziorowska, R.; Siffroi, J.-P.; Hajjar, R.J.; et al. Functional Human Beige Adipocytes From Induced Pluripotent Stem Cells. Diabetes 2017, 66, 1470-1478. [CrossRef]

187. Ang, L.T.; Tan, A.K.Y.; Autio, M.I.; Goh, S.H.; Choo, S.H.; Lee, K.L.; Tan, J.; Pan, B.; Lee, J.J.H.; Lum, J.J.; et al. A Roadmap for Human Liver Differentiation from Pluripotent Stem Cells. Cell Rep. 2018, 22, 2190-2205. [CrossRef] [PubMed]

188. Chiang, C.-H.; Chang, C.-C.; Huang, H.-C.; Chen, Y.-J.; Tsai, P.-H.; Jeng, S.-Y.; Hung, S.-I.; Hsieh, J.-H.; Huang, H.-S.; Chiou, S.-H.; et al. Investigation of Hepatoprotective Activity of Induced Pluripotent Stem Cells in the Mouse Model of Liver Injury. J. Biomed. Biotechnol. 2011, 2011, 1-11. [CrossRef]

189. Baxter, M.; Withey, S.; Harrison, S.; Segeritz, C.-P.; Zhang, F.; Atkinson-Dell, R.; Rowena, S.-Y.; Gerrard, D.T.; Sison-Young, R.; Jenkins, R.; et al. Phenotypic and functional analyses show stem cell-derived hepatocyte-like cells better mimic fetal rather than adult hepatocytes. J. Hepatol. 2015, 62, 581-589. [CrossRef]

190. Gao, X.; Liu, Y. A transcriptomic study suggesting human iPSC-derived hepatocytes potentially offer a better in vitro model of hepatotoxicity than most hepatoma cell lines. Cell Biol. Toxicol. 2017, 33, 407-421. [CrossRef]

191. Grant, R.; Hay, D.C.; Callanan, A. A Drug-Induced Hybrid Electrospun Poly-Capro-Lactone: Cell-Derived Extracellular Matrix Scaffold for Liver Tissue Engineering. Tissue Eng. Part A 2017, 23, 650-662. [CrossRef]

192. Grant, R.; Hallett, J.; Forbes, S.; Hay, D.; Callanan, A. Blended electrospinning with human liver extracellular matrix for engineering new hepatic microenvironments. Sci. Rep. 2019, 9, 1-12. [CrossRef]

193. Huse, S.M.; Gruppuso, P.A.; Boekelheide, K.; Sanders, J.A. Patterns of gene expression and DNA methylation in human fetal and adult liver. BMC Genom. 2015, 16, 981. [CrossRef]

194. Rashid, S.T.; Corbineau, S.; Hannan, N.; Marciniak, S.J.; Miranda, E.; Alexander, G.; Huang-Doran, I.; Griffin, J.; Ahrlund-Richter, L.; Skepper, J.; et al. Modeling inherited metabolic disorders of the liver using human induced pluripotent Stem Cells. J. Clin. Investig. 2010, 120, 3127-3136. [CrossRef] [PubMed] 
195. Yusa, K.; Rashid, S.T.; Strick-Marchand, H.; Varela, I.; Liu, P.-Q.; Paschon, D.E.; Miranda, E.; Ordóñez, A.; Hannan, N.R.F.; Rouhani, F.J.; et al. Targeted gene correction of $\alpha 1$-antitrypsin deficiency in induced pluripotent Stem Cells. Nat. Cell Biol. 2011, 478, 391-394. [CrossRef] [PubMed]

196. Song, Z.; Cai, J.; Liu, Y.; Zhao, D.; Yong, J.; Duo, S.; Song, X.; Guo, Y.; Zhao, Y.; Qin, H.; et al. Efficient generation of hepatocyte-like cells from human induced pluripotent Stem Cells. Cell Res. 2009, 19, 1233-1242. [CrossRef] [PubMed]

197. Grefte, S.; Kuijpers-Jagtman, A.M.; Torensma, R.; Hoff, J.W.V.D. Skeletal Muscle Development and Regeneration. Stem Cells Dev. 2007, 16, 857-868. [CrossRef] [PubMed]

198. Tremblay, P.; Gruss, P. Pax: Genes for mice and men. Pharmacol. Ther. 1994, 61, 205-226. [CrossRef]

199. Buckingham, M.; Bajard, L.; Chang, T.; Daubas, P.; Hadchouel, J.; Meilhac, S.; Montarras, D.; Rocancourt, D.; Relaix, F. The formation of skeletal muscle: From somite to limb. J. Anat. 2003, 202, 59-68. [CrossRef]

200. Weintraub, H.; Tapscott, S.J.; Davis, R.L.; Thayer, M.J.; Adam, M.A.; Lassar, A.B.; Miller, A.D. Activation of muscle-specific genes in pigment, nerve, fat, liver, and fibroblast cell lines by forced expression of MyoD. Proc. Natl. Acad. Sci. USA 1989, 86, 5434-5438. [CrossRef]

201. Darabi, R.; Arpke, R.W.; Irion, S.; Dimos, J.T.; Grskovic, M.; Kyba, M.; Perlingeiro, R.C.R. Human ES- and iPS-Derived Myogenic Progenitors Restore DYSTROPHIN and Improve Contractility upon Transplantation in Dystrophic Mice. Cell Stem Cell 2012, 10, 610-619. [CrossRef]

202. Borchin, B.; Chen, J.; Barberi, T. Derivation and FACS-mediated purification of PAX3+/PAX7+ skeletal muscle precursors from human pluripotent Stem Cells. Stem Cell Rep. 2013, 1, 620-631. [CrossRef]

203. De La Serna, I.L.; Roy, K.; Carlson, K.A.; Imbalzano, A.N. MyoD Can Induce Cell Cycle Arrest but Not Muscle Differentiation in the Presence of Dominant Negative SWI/SNF Chromatin Remodeling Enzymes. J. Biol. Chem. 2001, 276, 41486-41491. [CrossRef] [PubMed]

204. Bentzinger, C.F.; Wang, Y.X.; Rudnicki, M.A. Building Muscle: Molecular Regulation of Myogenesis. Cold Spring Harb. Perspect. Biol. 2012, 4, a008342. [CrossRef] [PubMed]

205. Shelton, M.; Metz, J.; Liu, J.; Carpenedo, R.L.; Demers, S.-P.; Stanford, W.L.; Skerjanc, I.S. Derivation and Expansion of PAX7-Positive Muscle Progenitors from Human and Mouse Embryonic Stem Cells. Stem Cell Rep. 2014, 3, 516-529. [CrossRef] [PubMed]

206. Xu, C.; Tabebordbar, M.; Iovino, S.; Ciarlo, C.; Liu, J.; Castiglioni, A.; Price, E.; Liu, M.; Barton, E.R.; Kahn, C.R.; et al. A Zebrafish Embryo Culture System Defines Factors that Promote Vertebrate Myogenesis across Species. Cell 2013, 155, 909-921. [CrossRef] [PubMed]

207. Chal, J.; Oginuma, M.; Al Tanoury, Z.; Gobert, B.; Sumara, O.; Hick, A.; Bousson, F.; Zidouni, Y.; Mursch, C.; Moncuquet, P.; et al. Differentiation of pluripotent Stem Cells to muscle fiber to model Duchenne muscular dystrophy. Nat. Biotechnol. 2015, 33, 962-969. [CrossRef]

208. Caron, L.; Kher, D.; Lee, K.L.; McKernan, R.; Dumevska, B.; Hidalgo, A.; Leslie, C.; Yang, H.; Main, H.; Ferri, G.; et al. A Human Pluripotent Stem Cell Model of Facioscapulohumeral Muscular Dystrophy-Affected Skeletal Muscles. Stem Cells Transl. Med. 2016, 5, 1145-1161. [CrossRef]

209. Chetty, S.; Pagliuca, F.W.; Honore, C.; Kweudjeu, A.; Rezania, A.; Melton, D.A. A simple tool to improve pluripotent stem cell differentiation. Nat. Methods 2013, 10, 553-556. [CrossRef]

210. Aulehla, A.; Pourquié, O. Signaling Gradients during Paraxial Mesoderm Development. Cold Spring Harb. Perspect. Biol. 2009, 2, a000869. [CrossRef]

211. Balhara, B.; Burkart, A.; Topcu, V.; Lee, Y.-K.; Cowan, C.; Kahn, C.R.; Patti, M.-E. Severe Insulin Resistance Alters Metabolism in Mesenchymal Progenitor Cells. Endocrinology 2015, 156, 2039-2048. [CrossRef]

212. Wang, L.; Schulz, T.C.; Sherrer, E.S.; Dauphin, D.S.; Shin, S.; Nelson, A.M.; Ware, C.B.; Zhan, M.; Song, C.-Z.; Chen, X.; et al. Self-renewal of human embryonic Stem Cells requires insulin-like growth factor-1 receptor and ERBB2 receptor signaling. Blood 2007, 110, 4111-4119. [CrossRef]

213. Burkart, A.M.; Tan, K.; Warren, L.; Iovino, S.; Hughes, K.J.; Kahn, C.R.; Patti, M.-E. Insulin Resistance in Human iPS Cells Reduces Mitochondrial Size and Function. Sci. Rep. 2016, 6, 22788. [CrossRef] [PubMed]

214. Anello, M.; Lupi, R.; Spampinato, D.; Piro, S.; Masini, M.; Boggi, U.; Del Prato, S.; Rabuazzo, A.M.; Purrello, F.; Marchetti, P. Functional and morphological alterations of mitochondria in pancreatic beta cells from type 2 diabetic patients. Diabetology 2005, 48, 282-289. [CrossRef] [PubMed]

215. Pravenec, M.; Hyakukoku, M.; Houstek, J.; Zidek, V.; Landa, V.; Mlejnek, P.; Miksik, I.; Dudová-Mothejzikova, K.; Pecina, P.; Vrbacký, M.; et al. Direct linkage of mitochondrial genome variation to risk factors for type 2 diabetes in conplastic strains. Genome Res. 2007, 17, 1319-1326. [CrossRef] 
216. Crawford, S.; Hoogeveen, R.C.; Brancati, F.L.; Astor, B.C.; Ballantyne, C.M.; Schmidt, M.I.; Young, J.H. Association of blood lactate with type 2 diabetes: The Atherosclerosis Risk in Communities Carotid MRI Study. Int. J. Epidemiol. 2010, 39, 1647-1655. [CrossRef] [PubMed]

217. Lovejoy, J.; Newby, F.; Gebhart, S.; DiGirolamo, M. Insulin resistance in obesity is associated with elevated basal lactate levels and diminished lactate appearance following intravenous glucose and insulin. Metabolism 1992, 41, 22-27. [CrossRef]

218. Ørtenblad, N.; Mogensen, M.; Petersen, I.; Højlund, K.; Levin, K.; Sahlin, K.; Beck-Nielsen, H.; Gaster, M. Reduced insulin-mediated citrate synthase activity in cultured skeletal muscle cells from patients with type 2 diabetes: Evidence for an intrinsic oxidative enzyme defect. Biochim. Biophys. Acta (BBA) Mol. Basis Dis. 2005, 1741, 206-214. [CrossRef]

219. Christe, M.; Hirzel, E.; Lindinger, A.; Kern, B.; Von Flüe, M.; Peterli, R.; Peters, T.; Eberle, A.N.; Lindinger, P.W. Obesity Affects Mitochondrial Citrate Synthase in Human Omental Adipose Tissue. ISRN Obes. 2013, 2013, 1-8. [CrossRef]

220. Amilon, K.R.; Cortes-Araya, Y.; Moore, B.; Lee, S.; Lillico, S.G.; Breton, A.; Esteves, C.L.; Donadeu, F.X. Generation of Functional Myocytes from Equine Induced Pluripotent Stem Cells. Cell. Reprogramm. 2018, 20, 275-281. [CrossRef]

221. Wu, J.; Boström, P.; Sparks, L.M.; Ye, L.; Choi, J.H.; Giang, A.-H.; Khandekar, M.; Virtanen, K.A.; Nuutila, P.; Schaart, G.; et al. Beige Adipocytes Are a Distinct Type of Thermogenic Fat Cell in Mouse and Human. Cell 2012, 150, 366-376. [CrossRef]

222. Cinti, S. The adipose organ at a glance. Dis. Model. Mech. 2012, 5, 588-594. [CrossRef]

223. Ema, X.; Elee, P.; Chisholm, D.J.; James, D.E. Control of Adipocyte Differentiation in Different Fat Depots; Implications for Pathophysiology or Therapy. Front. Endocrinol. 2015, 6, 1. [CrossRef]

224. Moseti, D.; Regassa, A.; Kim, W.-K. Molecular Regulation of Adipogenesis and Potential Anti-Adipogenic Bioactive Molecules. Int. J. Mol. Sci. 2016, 17, 124. [CrossRef] [PubMed]

225. Wang, Q.; Tang, J.; Gao, X.; Ruan, H.-B. Inhibition of PPAR Gamma, Adipogenesis, and Insulin Sensitivity by MAGED1. Diabetes 2018, 67, 1750. [CrossRef]

226. Linhart, H.G.; Ishimura-Oka, K.; DeMayo, F.; Kibe, T.; Repka, D.; Poindexter, B.; Bick, R.J.; Darlington, G.J. C/EBP is required for differentiation of white, but not brown, adipose tissue. Proc. Natl. Acad. Sci. USA 2001, 98, 12532-12537. [CrossRef]

227. Supruniuk, E.; Mikłosz, A.; Chabowski, A. The Implication of PGC-1 $\alpha$ on Fatty Acid Transport across Plasma and Mitochondrial Membranes in the Insulin Sensitive Tissues. Front. Physiol. 2017, 8. [CrossRef]

228. Seale, P.; Conroe, H.M.; Estall, J.; Kajimura, S.; Frontini, A.; Ishibashi, J.; Cohen, P.; Cinti, S.; Spiegelman, B.M. Prdm16 determines the thermogenic program of subcutaneous white adipose tissue in mice. J. Clin. Investig. 2011, 121, 96-105. [CrossRef]

229. Cohen, P.; Levy, J.D.; Zhang, Y.; Frontini, A.; Kolodin, D.P.; Svensson, K.J.; Lo, J.C.; Zeng, X.; Ye, L.; Khandekar, M.J.; et al. Ablation of PRDM16 and Beige Adipose Causes Metabolic Dysfunction and a Subcutaneous to Visceral Fat Switch. Cell 2014, 156, 304-316. [CrossRef]

230. Taura, D.; Noguchi, M.; Sone, M.; Hosoda, K.; Mori, E.; Okada, Y.; Takahashi, K.; Homma, K.; Oyamada, N.; Inuzuka, M.; et al. Adipogenic differentiation of human induced pluripotent Stem Cells: Comparison with that of human embryonic Stem Cells. FEBS Lett. 2009, 583, 1029-1033. [CrossRef]

231. Karam, M.; Younis, I.; Elareer, N.R.; Nasser, S.; Abdelalim, E.M. Scalable Generation of Mesenchymal Stem Cells and Adipocytes from Human Pluripotent Stem Cells. Cells 2020, 9, 710. [CrossRef]

232. Pettinato, G.; Wen, X.; Zhang, N. Formation of Well-defined Embryoid Bodies from Dissociated Human Induced Pluripotent Stem Cells using Microfabricated Cell-repellent Microwell Arrays. Sci. Rep. 2014, 4, 7402. [CrossRef]

233. Mori, E.; Fujikura, J.; Noguchi, M.; Nakao, K.; Matsubara, M.; Sone, M.; Taura, D.; Kusakabe, T.; Ebihara, K.; Tanaka, T.; et al. Impaired adipogenic capacity in induced pluripotent Stem Cells from lipodystrophic patients with BSCL2 mutations. Metabolism 2016, 65, 543-556. [CrossRef] [PubMed]

234. Noguchi, M.; Hosoda, K.; Nakane, M.; Mori, E.; Nakao, K.; Taura, D.; Yamamoto, Y.; Kusakabe, T.; Sone, M.; Sakurai, H.; et al. In Vitro Characterization and Engraftment of Adipocytes Derived from Human Induced Pluripotent Stem Cells and Embryonic Stem Cells. Stem Cells Dev. 2013, 22, 2895-2905. [CrossRef] [PubMed] 
235. Marquez, M.P.; Alencastro, F.; Madrigal, A.; Jimenez, J.L.; Blanco, G.; Gureghian, A.; Keagy, L.; Lee, C.; Liu, R.; Tan, L.; et al. The Role of Cellular Proliferation in Adipogenic Differentiation of Human Adipose Tissue-Derived Mesenchymal Stem Cells. Stem Cells Dev. 2017, 26, 1578-1595. [CrossRef] [PubMed]

236. Xu, C.; He, J.; Jiang, H.; Zu, L.; Zhai, W.; Pu, S.; Xu, G. Direct effect of glucocorticoids on lipolysis in adipocytes. Mol. Endocrinol. 2009, 23, 1161-1170. [CrossRef] [PubMed]

237. Agarwal, A.K.; I Barnes, R.; Garg, A. Genetic basis of congenital generalized lipodystrophy. Int. J. Obes. 2003, 28, 336-339. [CrossRef] [PubMed]

238. Kishida, T.; Ejima, A.; Yamamoto, K.; Tanaka, S.; Yamamoto, T.; Mazda, O. Reprogrammed Functional Brown Adipocytes Ameliorate Insulin Resistance and Dyslipidemia in Diet-Induced Obesity and Type 2 Diabetes. Stem Cell Rep. 2015, 5, 569-581. [CrossRef] [PubMed]

239. Su, S.; Guntur, A.R.; Nguyen, D.C.; Fakory, S.S.; Doucette, C.C.; Leech, C.; Lotana, H.; Kelley, M.; Kohli, J.; Martino, J.; et al. A Renewable Source of Human Beige Adipocytes for Development of Therapies to Treat Metabolic Syndrome. Cell Rep. 2018, 25, 3215-3228.e9. [CrossRef]

240. Lizcano, F.; Vargas, D.; Gómez, Á.; Torrado, A. Human ADMC-Derived Adipocyte Thermogenic Capacity Is Regulated by IL-4 Receptor. Stem Cells Int. 2017, 2017, 1-10. [CrossRef]

241. Jiang, Y.; Berry, D.C.; Graff, J.M. Distinct cellular and molecular mechanisms for $\beta 3$ adrenergic receptor-induced beige adipocyte formation. eLife 2017, 6, e30329. [CrossRef]

242. Mohsen-Kanson, T.; Hafner, A.-L.; Wdziekonski, B.; Takashima, Y.; Villageois, P.; Carrière, A.; Svensson, M.; Bagnis, C.; Chignon-Sicard, B.; Svensson, P.-A.; et al. Differentiation of Human Induced Pluripotent Stem Cells into Brown and White Adipocytes: Role of Pax3. Stem Cells 2014, 32, 1459-1467. [CrossRef]

243. Miura, K.; Okada, Y.; Aoi, T.; Okada, A.; Takahashi, K.; Okita, K.; Nakagawa, M.; Koyanagi, M.; Tanabe, K.; Ohnuki, M.; et al. Variation in the safety of induced pluripotent stem cell lines. Nat. Biotechnol. 2009, 27, 743-745. [CrossRef] [PubMed]

244. Kajiwara, M.; Aoi, T.; Okita, K.; Takahashi, R.; Inoue, H.; Takayama, N.; Endo, H.; Eto, K.; Toguchida, J.; Uemoto, S.; et al. Donor-dependent variations in hepatic differentiation from human-induced pluripotent Stem Cells. Proc. Natl. Acad. Sci. USA 2012, 109, 12538-12543. [CrossRef] [PubMed]

245. Suhr, S.T.; Chang, E.A.; Tjong, J.; Alcasid, N.; Perkins, G.A.; Goissis, M.D.; Ellisman, M.H.; Perez, G.I.; Cibelli, J.B. Mitochondrial Rejuvenation After Induced Pluripotency. PLoS ONE 2010, 5, e14095. [CrossRef] [PubMed]

246. Kim, K.; Doi, A.; Wen, B.; Ng, K.; Zhao, R.; Cahan, P.; Kim, J.; Aryee, M.J.; Ji, H.; Ehrlich, L.I.R.; et al. Epigenetic memory in induced pluripotent Stem Cells. Nature 2010, 467, 285-290. [CrossRef]

247. Helman, A.; Cangelosi, A.L.; Davis, J.C.; Pham, Q.; Rothman, A.; Faust, A.L.; Straubhaar, J.R.; Sabatini, D.M.; Melton, D.A. A Nutrient-Sensing Transition at Birth Triggers Glucose-Responsive Insulin Secretion. Cell Metab. 2020, 31, 1004-1016.e5. [CrossRef]

248. Jaafar, R.; Tran, S.; Shah, A.N.; Sun, G.; Valdearcos, M.; Marchetti, P.; Masini, M.; Swisa, A.; Giacometti, S.; Bernal-Mizrachi, E.; et al. mTORC1-to-AMPK switching underlies $\beta$ cell metabolic plasticity during maturation and diabetes. J. Clin. Investig. 2019, 129, 4124-4137. [CrossRef]

249. Higuchi, A.; Ling, Q.-D.; Kumar, S.S.; A Munusamy, M.; A Alarfaj, A.; Chang, Y.; Kao, S.-H.; Lin, K.-C.; Wang, H.-C.; Umezawa, A. Generation of pluripotent Stem Cells without the use of genetic material. Lab. Investig. 2014, 95, 26-42. [CrossRef]

250. Higuchi, A.; Ling, Q.-D.; Kumar, S.S.; Munusamy, M.; Alarfajj, A.A.; Umezawa, A.; Wu, G.-J. Design of polymeric materials for culturing human pluripotent Stem Cells: Progress toward feeder-free and xeno-free culturing. Prog. Polym. Sci. 2014, 39, 1348-1374. [CrossRef]

251. Agulnick, A.D.; Ambruzs, D.M.; Moorman, M.A.; Bhoumik, A.; Cesario, R.M.; Payne, J.K.; Kelly, J.R.; Haakmeester, C.; Srijemac, R.; Wilson, A.Z.; et al. Insulin-Producing Endocrine Cells Differentiated In Vitro From Human Embryonic Stem Cells Function in Macroencapsulation Devices In Vivo. Stem Cells Transl. Med. 2015, 4, 1214-1222. [CrossRef]

252. Wan, J.; Huang, Y.; Zhou, P.; Guo, Y.; Wu, C.; Zhu, S.; Wang, Y.; Wang, L.; Lu, Y.; Wang, Z. Culture of iPSCs Derived Pancreatic $\beta$-Like Cells In Vitro Using Decellularized Pancreatic Scaffolds: A Preliminary Trial. BioMed Res. Int. 2017, 2017, 4276928. [CrossRef] 
253. Xu, H.; Wang, B.; Ono, M.; Kagita, A.; Fujii, K.; Sasakawa, N.; Ueda, T.; Gee, P.; Nishikawa, M.; Nomura, M.; et al. Targeted Disruption of HLA Genes via CRISPR-Cas9 Generates iPSCs with Enhanced Immune Compatibility. Cell Stem Cell 2019, 24, 566-578.e7. [CrossRef] [PubMed]

254. Han, X.; Wang, M.; Duan, S.; Franco, P.J.; Kenty, J.H.-R.; Hedrick, P.; Xia, Y.; Allen, A.; Ferreira, L.M.R.; Strominger, J.L.; et al. Generation of hypoimmunogenic human pluripotent Stem Cells. Proc. Natl. Acad. Sci. USA 2019, 116, 10441-10446. [CrossRef] [PubMed]

Publisher's Note: MDPI stays neutral with regard to jurisdictional claims in published maps and institutional affiliations.

(C) 2020 by the authors. Licensee MDPI, Basel, Switzerland. This article is an open access article distributed under the terms and conditions of the Creative Commons Attribution (CC BY) license (http://creativecommons.org/licenses/by/4.0/). 